A Technology

Assessment of

Solar Energy Systems

\title{
Environmental and Economic Evaluation of Energy Recovery from Agricultural and Forestry Residues
}

\section{MASTER}

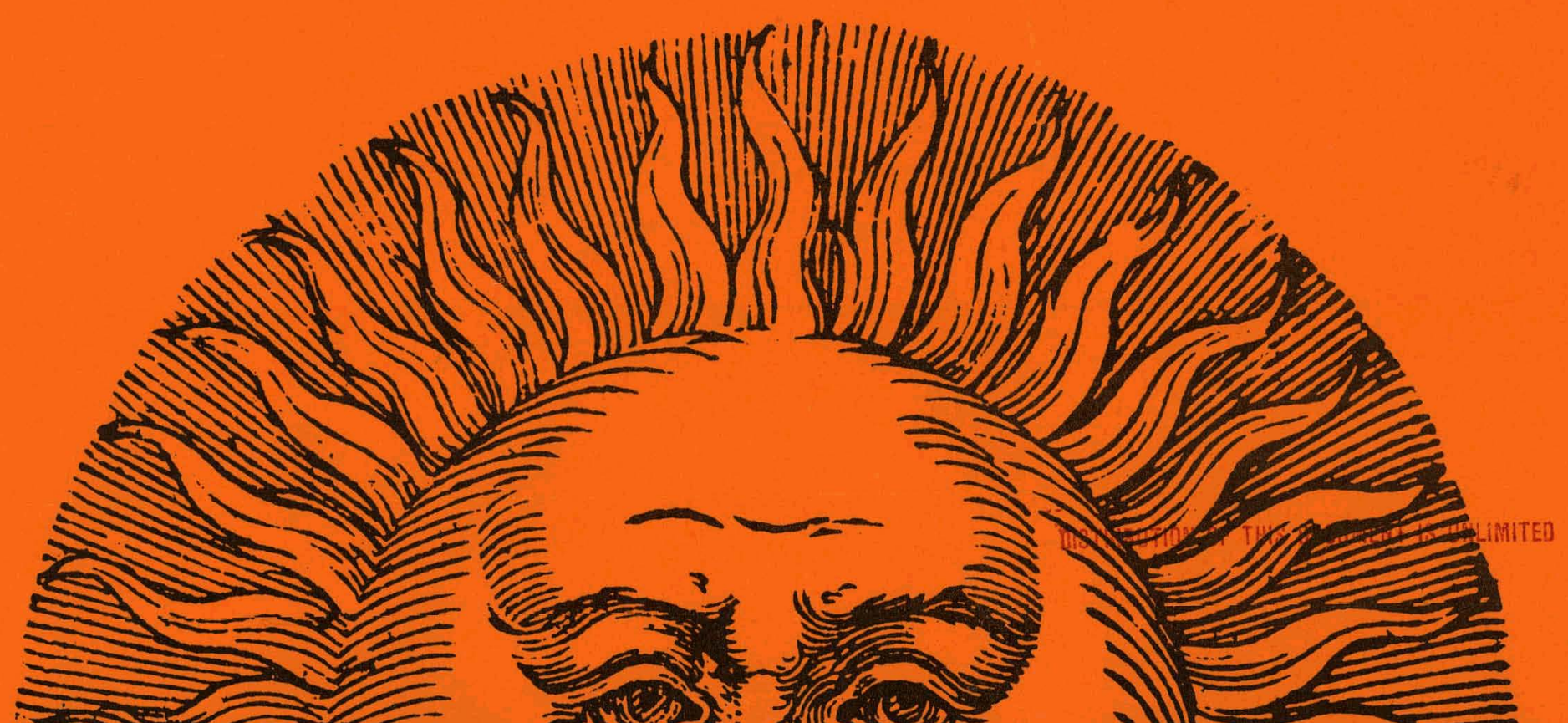




\section{DISCLAIMER}

This report was prepared as an account of work sponsored by an agency of the United States Government. Neither the United States Government nor any agency Thereof, nor any of their employees, makes any warranty, express or implied, or assumes any legal liability or responsibility for the accuracy, completeness, or usefulness of any information, apparatus, product, or process disclosed, or represents that its use would not infringe privately owned rights. Reference herein to any specific commercial product, process, or service by trade name, trademark, manufacturer, or otherwise does not necessarily constitute or imply its endorsement, recommendation, or favoring by the United States Government or any agency thereof. The views and opinions of authors expressed herein do not necessarily state or reflect those of the United States Government or any agency thereof. 


\section{DISCLAIMER}

Portions of this document may be illegible in electronic image products. Images are produced from the best available original document. 
Printed in the United States of America

$$
\text { Available from }
$$

National Technical Information Service

U.S. Department of Commerce

5285 Port Royal Road

Springfield, VA 22161

NTIS price codes

$$
\text { Printed Copy: } \quad \$ 9.00
$$

Microfiche Copy: $\$ 3.50$ 


\section{A Technology Assessment of Solar Energy Systems}

\section{Environmental and Economic Evaluation of Energy Recovery from Agricultural and Forestry Residues}

Prepared by:

Argonne National Laboratory

U.S. Department of Energy

Assistant Secretary for Environment Office of Environmental Assessments Washington, D.C. 20545

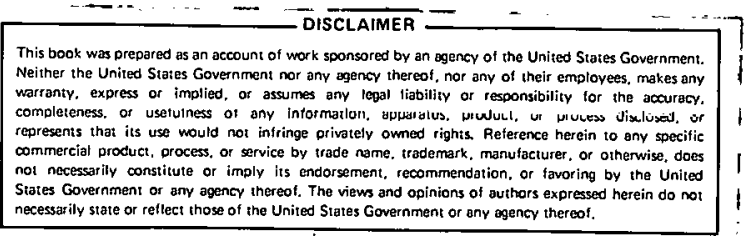


FORWARD

The U. S. Department of Energy, Office of Environment, Office of Environmenta Assessments, is conducting a project entitled Technology Assessment of Solar Energy (TASE) Systems, to evaluate the range of potential environmental, health, and socioeconomic consequences of rapid, large-scale commercialization of solar technologies. The goal of this project is to identify and analyze both the positive and negative effects of solar technology deployment. The project will provide a basis for avoiding potential problems and for grasping opportunities during the transition to solar energy in the U. S.

Massive solar development will force major increases in the use of those raw materials needed to make solar system components. Along with this increased resource consumption and production will come associated pollution. In addition, rapid solar energy development may mean significant secondary or unplanned changes in institutions and lifestyles as the nation moves toward greater use of solar energy systems. The TASE project is designed to provide a quantitative analysis of the direct and indirect effects of solar energy use. In so doing, it will help define an environmentally acceptable solar future.

This report is an element of the TASE Solar Technology Characterization Series. We would like to express our appreciation to Terry Surles of the Argonne National Laboratory for his efforts in preparing this document.

Dr. Gregory J. D'Alessio

TASE Pro.ject Director

Technology Assessments Division

Dr. Robert P. Blaunstein, Manager

Conservation, Solar, and Geothermal Programs

Technology Assessments Division 
Agricultural and forestry residues have been converted to energy for centuries. The technologies employed range from straightforward approaches such as combustion to produce heat to more involved approaches such as pyrolysis of the residues to produce medium-Btu synthetic gas, charcoal, and oil. Thus there is no one technology that can be characterized as the best or most promising for conversion of agricultural and forestry residues into energy. Selection of the appropriate conversion method depends on several factors, e.g., the chemical composition of the residue, the quantity present, the immediate need for energy near the site of production, and the economics of the process. Therefore, to accurately assess the potential of agricultural and forestry residues as energy resources, an array of current conversion options should be addressed.

Four conversion methods and five residues are examined in this report, which describes six model systems: hydrolysis of corn residues, pyroly$s$ is of corn residues, combustion of cotton-ginning residues, pyrolysis of wheat residues, fermentation of molasses (i.e., sugar processing waste), and combustion of pulp and papermill wastes. Estimates of material and energy flows for those systems are given per $10^{12}$ Btu of recovered energy.

Regional effects are incorporated by addressing the regionalized production of the residues. A national scope cannot be provided for every residue considered because of the biological and physical constraints of crop production (e.g., cotton does not grow well in Illinois). Thus, regionalization of the model systems to the primary production region for the crop from which the residue is obtained has been undertaken. The associated environmental consequences of residue utilization are then assessed for the production region. In addition, the environmental impacts of operating the model systems are examined by quantifying the residuals generated and the land, water, and material requirements per $10^{12}$ Btu of energy generated.

On the basis of estimates found in the literature, capital, operating, and maintenance cost estimates are given for the model systems. These data are also computed on the basis of $10^{12} \mathrm{Btu}$ of energy recovered. The cost, residual, material, land, and water data were then organized into a format acceptable for input into the SEAS data management program.

The study indicates that the most serious environmental impacts arise from residue removal rather than from conversion. Therefore, future development of the technology lies in the development of cropping systems capable of residue removal as much as in the development of improved conversion processes. This conclusion is important for the future development of agricultural and silvicultural residues as biomass energy resources. 
PREFACE . . . . . . . . . . . . . . . . . . . . . . . . . $\mathrm{.}$. .

EXECUTIVE SUMMARY . . . . . . . . . . . . . . . . . . . . . v v

1. COMBUSTION OF COTTON GIN RESIDUES. ..................... . 1

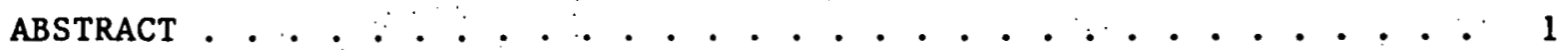

$1: 1$ INTRODUCTION. . . . . . . . . . . . . . . . . . . . 1

1.1.1 General System Description . . . . . . . . . . . . . 1

1.1.2 Resource Distribution . . . . . . . . . . . 2

1.2 DESCRIPTION OF MODEL SYSTEM . . . . . . ............ . . 4

1.2 .1 System Description . . . . . . . . . . . . . . . . 4

1.2 .2 Equipment. . . . . . . . . . . . . . . . . . 5

1.2.3 Energy and Material Flows. . . ............ 5

1.3 ENVIRONMENTAL DATA. . . . . . . . . . . . . . . . . . 7

1.3.1 General Soil Effects.................. . 7

1.3.2 Some Aspects of Cotton Residue Removal . . . . . . . . 8

$1: 3.3$ Operating Residuals. . . . . . . . . . . . . 8

1.4 ECONOMIC DATA . . . . . . . . . . . . . . . . . . . . . 10

1.4.1 Capital Costs. . . . . . . . . . . . . . . . . . 10

1.4 .2 Operating and Maintenance Costs. . . . . . . . . . . . 11

1.5 SUMMARY OF FINDINGS . . . . . . . . . . . . . . . . . 13

REFERENCES . . . . . . . . . . . . . . . . . . . . 15

2 COGENERATION FROM BLACK LIQUOR AND BARK AND WOOD RESIDUES. • . • • . 19

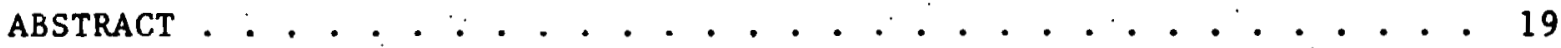

2.1 INTRODUCTION. . . . . . . . . . . . . . . . . . . . 19

2.1.1 General System Description............... . 19

2.1.2 Resource Characteristics... . . . . . . . . . 20

2.2 DESCRIPTION OF MODEL SYSTEM . . . . . . . . . . . . . . 20

2.2 .1 Technology Involved. . : . . . . . . . . . . . . . . 20

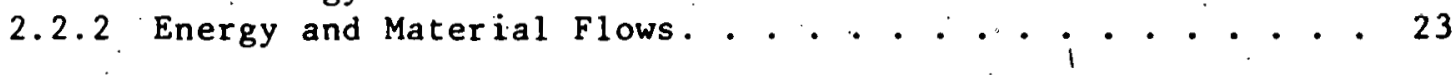

2.3 ENVIRONMENTAL DATA. . . . . . . . . . . . . . . . . . 23

2.3.1 Environmental Consequences of Residue Utilization. . . . 23

2.3 .2 Land Requirements. . . . . . . . . . . . . . . 26

2.3.3 Water Requirements . . . . . . . . . . . . . . . 26

2.3.4 Operating Residuals. . . . . . . . . . . . 26 
2.4 ECONOMIC DATA . . . . . . . . . . . . . . . . . . . . . . 29

2.4.1 Capital Costs. . . . . . . . . . . . . . . . . . . . 29

2.4.2 Operating and Maintenance Costs. . . . . . . . . . . 31

2.5 SUMMARY OF FINDINGS ......................... 31

REFERENCES . . . . . . . . . . . . . . . . . . . . . 33

3 HYDROLYSTIS OF CORN RESIDUES TO OBTAIN FURFURAL . . . . . . . . . . . 35

ABSTRACT . . . . . . . . . . . . . . . . . . . 35

3.1 INIRUDUCTION. . . . . . . . . . . . . . . . . . . . 35

3.1.1 General Systems Desrription. . . . . . .. . . . . . . 35

3.1.2 Resource Distribution. . . . . . . . . . . . 35

3.2 DESCRIPTION OF MODEL SYSTEM . . . . . . . . . . . . . . . . 37

3.2.1 System Description . . . . . . . . . . . . . . . . 37

3.2.2 Material Requirements. . . . . . . . . . . . . . 40

3.3 ENVIRONMENTAL DATA. . . . . . . . . . . . . . . . . . . 40

3.3.1 General Soil Effects................... . 40

3.3.2 Some Aspects of Corn Residue Removal . . . . . . . . . 42

3.3.3 Operating Residuals. . . . . . . . . . . . . . . . 44

3.3 .4 Land Requirements. . . . . . . . . . . . . . . 45

3.3.5 Water Requirements... . . . . . . . . . . . . . 45

3.4 ECONUMIL DATA . . . . . . . . . . . . . . . . . . . . . . 46

3.4.1 Capital Costs. . . . . . . . . . . . . . . . 46

3.4.2 Uperating Costs. . . . . . . . . . . . . . . . 46

3.5 SIMMARY OF FINDINGS . . . . . . . . . . . . . . . . . 49

REFERENCES . . . . . . . . . . . . . . . . . . . . . 51

4 CORN RESIDUE PYROLYSIS (GASIFICATION). . . . . . . . . . . . . 55

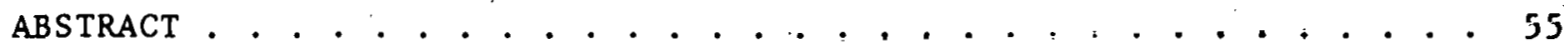

4.1 INTRODUCTION. . . . . . . . . . . . . . . . . . . . . 55

4.1.1 General System Description . . . . . . . . . . . 55

4.1.2 Resqurct Dietributioni. . . . . . . . . . . . . . 57

4.2 DESCRIPTION OF MODEL SYSTEM . . . . . . . . . . . . . . . . 60

4.2.1 System Description and Equipment . . . . . . . . . . . 60

4.2.2 Energy and Material Flows. . . . . . . . . . . . . . 62

4.3 ENVIRONMENTAl DATA. . . . . . . . . . . . . . . . . . 62

4.3.1 General Soil Effects................. . . 62

4.3.2 Some Aspects of Corn Residue Removal . . . . . . . . 63 
4.3.3 Operating Residuals.................. 66

4.3.4 Land Requirements.................... 66

4.3.5 Water Requirements . . . . . . . . . . . . 67

4.4 ECONOMIC DATA . . . . . . . . . . . . . . . . . . 67

4.4.1 Capital Costs. . . . . . . . . . . . . . . . 67

4.4.2 Operating and Maintenance Costs. . . . . . . . . . 67

4.5 SUMMARY OF FINDINGS ..................... . . 67

REFERENCES . . . . . . . . . . . . . . . . . . . . 71

5 WHEAT RESIDUE PYROLYSIS (GASIFICATION) . . . . . . . . . . . . 75

ABSTRACT . . . . . . . . . . . . . . . . . . . 75

5.1 INTRODUCTION. . . . . . . . . . . . . . . . . . . . . 75

5.1.1 General System Description . . . . . . . . . . . . 75

5.1 .2 Resource Distribution. . . . . . . . . . . . . . 77

5.2 DESCRIPTION OF MODEL SYSTEM . . . . . . . . . . . . . . . . . 77

5.2.1 System Description and Equipment . . . . . . . . . . . 77

5.2 .2 Energy and Material Flows. . ... . . . . . . . . 81

5.3 ENVIROMMENTAL DATA. . . . . . . . . . . . . . . . . . 81

5.3.1 General Soil Effects . . . . . . . . . . . . . . 81

5.3.2 Some Aspects of Wheat Residue Removal. . . . . . . . 83

5.3 .3 Operating Residuals. . . . . . . . . . . . . . 85

5.3 .4 Land Requirements. . . . ............. . 85

5.3.5 Water Requirements................ 86

5.4 ECONOMIC DATA . . . . . . . . . . . . . . . . . . 86

5.4.1 Capital Costs. . . . . . . . . . . . . . . . 86

5.4.2 Operating and Maintenance Costs. . . . . . . . . . 86

5.5 SUMMARY OF FINDINGS . . . . . . . . . . . . . . . . . . 87

REFERENCES . . . . . . . . . . . . . . . . . . . . . . 89

6 FERMENTATION OF SUGAR PROCESSING RESIDUES (MOLASSES) . . . . . . . . 93

ABSTRACT . . . . . . . . . . . . . . . . . . . . 93

6.1 INTRODUCTION. . . . . . . . . . . . . . . . . . . . . . . . . 93

6.1.1 General System Description . . . . . . . . . . . . . 93

6.1.2 Resource Distribution. . . . . . . . . . . . . 93 
6.2 DESCRIPTION OF MODEL SYSTEM . . . . . . . . . . . . 96

6.2.1 System Description . . . . . . . . . . . . . . . 96

6.2.2 Material, Energy, and Equipment Requirements $: \therefore \ddots_{-} \cdot 98$

6.3. ENVIRONMENTAL DATA. . . . . . . . . . . . . . . . . 9 98

6.3 .1 Resource Factors . . . . . . . . . . . . . . . . 98

6.3 .2 Operating Residua1s. . . . . . . . . . . . . . 100

6.3.3 Land Requirements. . . . . ............. . . 100

6.3 .4 Water Requirements . . . . . . . . . . . . . . 100

6.4 ECONOMIC DATA . : : . . . . . . . . . . . . . . . . . 100

6.4.1 Capital Costs.". . . . . . . . . . . . . . . . . 100

6.4.2 Operating Costs. . . . . . . . . . . . . . . 101

6.5 SUMMARY OF FINDINGS .... . . . . . . . . . . . . . 101

REFERENCES ............................ . . . . . . . . . . . . . . 


\section{LIST OF FIGURES}

No.

1 COMBUSTION OF COTTON GIN RESIDUES

1.1 Cotton Harvested, 1969...................... 3

1.2 Flow of Energy and Material in the Cotton Residue

Combustion system . . . . . . . . . . . . . . . . 6

2 COGENERATION PROM BARK AND WOOD RESIDUES

2.1 The Kraft Process . . . . . . . . . . . . . . . . . . . . . . . 21

2.2 Model Cogeneration System for Bark and Wood Residues. . . . . . 24

3 HYDROLYSIS OF CORN RESIDUES FOR FURPURAL

3.1 Corn harvested, 1969. . . . . . . . . . . . . . . . 36

3.2 Process Flow Diagram for Production of Furfural

from Corn Residues. . . . . . . . . . . . . . . . 38

4 CORN RESIDUE PYROLYSIS (GASIFICATION)

4.1 Corn Hervested, 1969...................... . 59

5 WHEAT RESIDUE PYROLYSIS (GASIFICATION)

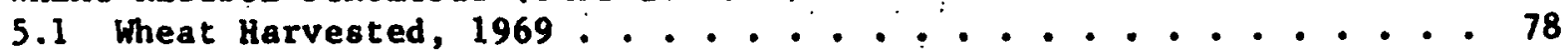

6 FERMENTATION OF SUGAR PROCESSING RESIDUES (MOLA8SES)

6.1 Sugar Beets Harvested for Sugar, Class 1-5 Parm8, 1969. . .. . . 94

6.2 Sugarcane harvested for Sugar, Cl888 1-5 Faras, 1969. . . . . . 95

6.3 Ethanol Production by Fermentation. . . . . . . . . . . . . 97 


\section{LIST OF TABLES}

No.

Title

Page

1 COMBUSTION OF COTTON GIN RESIDUES

1.1 Cotton Lint and Gin Residue Production and Energy

Value of Residues .. . . . . . . . . . . . . . . . . . . . 2

1.2 Type and Quantity of Ginning Wastes and. Their Fuel Values

Obtained from Mississippi Delta Spindle-Picked Cotton

and Texas High Plains Stripper-Harvested Cotton per 500

Pounds of Lint Ginned . . . . . . . . . . . . . . . . . . . . . . 4

1.3 Dry Weight Relationship Between Cotton Gin Residue and

Lint.. . . . . . . . . . . . . . . . . . . . . . . . . 5

1.4 Material and Energy Flows for Cotton Residue

Combustion System . . . . . . ................. 7

1.5 Inputs Needed to Obtain a Cotton Yield of 1,500 Pounds per

Acre of Lint and Seed ... . . . . . . . . . . . . . . . . . . . 9

1.6 Nutrients and Mineral Matler Removed by Sotton Crop....... . 9

1.7 A1r Emissions from Combustion of Biomass and

Related Materials . . . . . . . . . . . . . . . . . . . . . 10

1.8 Residuals Data for Combustion of Cotton Residues. . . . . . . . 11

1.9 Capital Costs for Model System for

Combustion of Cotton Gin Residues for Process Heat. . . . . . . . 12

1.10 Capital Expenditures and Materials Summary for Model

System for Combustion of Cotton Gin Residues for

Process Heat. . . . . . . . . . . . . . . . . . . . . . . . 12

1.11 Cotton Gin Residue Combustion Input/Output Summary. . . . . . . 14

2 COGENERATION FROM BARK AND WOOD RESIDUES

2.1 Material and Energy Flows for Energy Recovery from Model

Residue-Conversion System . . . . . . . . . . . . . . 25

2.2 Residuals Data for Combustion/Cogeneration from Black Liquor and Bark and Wood Residues. . . . . . . . . . . . . . . . . . 27

2.3 Construction Costs of Model System for Combustion/Cogeneration frm Bl ack Liquor and Bark and Wood Residues. . . . . . . . . . . 28

2.4 Capital Expenditures, Materials Requirements, and Energy Summary for Combustion/Cogeneration from Black Liquor and Bark and Wood Residues per $10^{12}$ Btu. . . . . . . . . . . . . . . 28

2.5 Energy Generation from Black T,i qun r and Bark and Houd Residues. . 32

3 HYDROLYSIS OF CORN RESIDUES FOR FURFURAL

3.1 Pentosan Content and Furfural Yield for Selected

Agricultural Residues... . . . . . . . . . . . . . . . 37

3.2 Corn - Grain and Residue Production and Energy Value of

Residues: Three Midwestern States and U.S., 1976 . . . . . . . 39

3.3 Chenical Composition of Solid Residue By-Product from

Furfural Production.. . . . . . . . . . . . . . . . . . 4 40

3.4 Material and Energy Flows for Model Furfural Production

System. . . . . . . . . . . . . . . . . . . . . . 4 41

3.5 Inputs per Year Needed to Obtain a Corn Yield of 107 Bushels of Grain and 3.21 Tons of Residue per Acre under Continuous Cropping System in Illinois . . . . . . . . . . . . . . . . . 42

3.6. Nutrients and Mineral Matter Removed by Corn Crop . . . . . . . . 43

3.7 Nutrients Lost by Soil Erosion under Continuous Corn Pro-

duction with Two Residue-Management Techniques. . . . . . . . . . 44 
3.8 Nutrient Replacement Required when Corn Residue is Removed for Furfural Production . . . . . . . . . . . . 45

3.9 Residuals Data for Hydrolysis of Corn Residues. . . . . . . . 45

3.10 Anticipated Distribution of Capital Costs for a Multiprocess Plant. . . . . . . . . . . . . . . . . 46

3.11 Capital Costs for Model System for Hydrolysis of Corn Residues. . . . . . . . . . . . . . . . . . . 47

3.12 Capital Expenditures and Materials Requirements for Model System for Hydrolysis of Corn Residues per $10^{12}$ Btu Output. . . . . . . . . . . . . . . . . 48

3.13 Estimated Annual Operating Costs for Furfural Facility. . . . . . 48

3.14 Input/Output Summary of Furfural Production by Hydrolysio of Corn Residues. . . . . . . . . . . . . . . 50

4 CORN RESIDUE PYROLYSIS (GASIFICATION)

4.1 Conversion of Various Cellulosic Wastes to oil. . . . . . . . . 56

4.2 Properties of No. 6 Fuel $0 i 1$ and a Typical Pyrolytic 0il. . . . 56

4.3 Characteristics of a True Pyrolytic Gas and Gasifier Gas. . - . 57

4.4 Analysis of Pyrolytic Chars from Organic Solid Wastes . . . . . . 58

4.5 Corn - Grain and Residue Production and Energy Value of Residues: Three Midwestern States and U.S., 1976 . . . . . . 58

4.6 Performance and Energy Inputs for Gasification of Agricultural and Forestry Residues. . . . . . . . . . . . 60

4.7 Energy Outputs from Gasification of Agricultural and Forestry Residues... . . . . . . . . . . . . . . 61

4.8 Material and Energy Flows for Gasification of Corn Residues at $20 \%$ Moisture. . . . . . . . . . . . . . . 62

4.9 Inputs per Year Needed to Obtain a Corn Yield of $10^{7}$ Bushels of Corn and 3.21 Tons of Residue per Acre under Continuous Cropping Systems in Illinois. . . . . . . . . . . . . . . . . 64

4.10 Nutrients and Mineral Matter Removed by Corn Crop . . . . . . . 65

4.11 Nutrients Lost by Soil Erosion under Continuous Corn Production with Two Residue-Management Techniques . . . . . . . . 65

4.12 Nutrient Replacement Required when Corn Residue is Removed for Pyrolysis... . . . . . . . . . . . . . . . 66

4.13 Construction Coste for a Gasification Unit. . . . . . . . . . 68

4.14 Capital Costs of a Gasification Unit per $10^{12}$ Btu Output. . . . 68

4.15 Input/Output Summary for Pyrolysis of Corn Residues... . . . 69

5 WHEAT RESIDUE PYROLYSIS (GASIFICATION)

5.1 Conversion of Various Celulosic Wastes to Oil . . . . . . . . 76

5.2 Properties of No. 6 Fuel 0 il and Pyrolytic Oil. . . . . . . 76

5.3 Characteristics of Pyrolytic Gas and Gasifier Gas . . . . . . . . 79

5.4 Analysis of Pyrolytic Chars from Organic Solid Wastes . . . . . . 80

5.5 Wheat - Grain and Residue Production and Energy Value of Residues: Six States and U.S., 1976. . . . . . . . . . . 80

5.6 Analysis of Corncobs and Wheat Straw (Dry Basis). . . . . . . 81 
5.7 Material and Energy Flows for Gasification of Wheat Residues at 20\% Moisture Content . . . . . . . . . . . . . . . 82

5.8 Inputs Needed to Obtain a Wheat Yield of 30 Bushels of Grain and 2.5 Tons of Residue per Acre in a Monoculture Cropping System. . . . . . . . . . . . . . . . . . . . . . 83

5.9 Nutrients and Mineral Matter Removed by Wheat Crop. . . . . . 84

5.10 Nutrient Replacement Required when Wheat Residue is Removed for Pyrolysis . . . . . . . . . . . . . . . . . . 85

5.11 Construction Costs for Model Gasification Unit. . . . . . . . . 86

5.12 Capital Costs per $10^{12}$ Btu Output for Model Gasification Unit . 87

5.13 Input/Output Summary for Pyrolysis of Wheat Residues. . . . . . 88

6 FERMENTATION OF SUGAR PROCESSING RESIDUES (MOLASSES)

6.1 Composition of Fusel oil. . . . . . . . . . . . . . . . . 98

6.2. Marerial and Energy Flows for Fermentration of Molesses. . . . . 99

6.3. Anticipated Distribution of Capital Costs for a Multiprocess Plant........................ 101

6.4 Capical Costs for Fermentation of Molasses. . . . . . . . . . 102

6.5 Capital Costs for Fermentation of Molasses per $10^{12}$ Btu Output. . . . . . . . . . . . . . . . . . . . . 103

6.6 Estimated Annual Operating and Maintenance Costs for Ethanol Facility. . . . . . . . . . . . . . . . . . . 103

6.7 Input/Output Summary for Fermentation of Molasses... . . . . 104 
1 COMBUSTION OF COTTON GIN RESIDUES

\author{
ABSTRACT
}

This section contains an analysis of capital and environmental costs of energy recovery from cotton-ginning residues through direct combustion. The analysis concentrates on data from Arkansas, Mississippi, and Texas, which are representative of the country's major cotton-producing areas. A model system for seed-cotton drying based on current designs is used to evaluate the conversion technology. Results of the analysis indicate that use of cotton-ginning residues for drying cotton lint would conserve significant quantities of natural gas and other fuels now used but that excess removal of residues can have a deleterious effect on the soil. Maintaining favorable chemical and structural properties of the soil over several crop years could be more costly, in terms of energy required for fertilizer, than the amount of energy in the residues.

\title{
1.1 INTRODUCTION
}

\subsubsection{General System Description}

This section concerns the direct combustion of cotton-ginning residues to produce process heat for drying the cotton lint at the ginning facility. Use of these residues for process heat would not only solve a solid waste disposal problem (i.e., the ginning residue) but would also conserve significant quantities of natural gas and other fuels now being used to dry cotton lint. This study provides an accounting of the material and energy flows for incineration of these residues, estimates of the associated capital and operating costs, and quantification of the residuals produced during conversion of the residues.

Before harvesting, cotton fields are sprayed with either desiccants or defoliants, such as pentachlorophenol, calcium cyanamide, sodium chlorate - borate mixtures, magnesium chlorate, aminotriazole, and tributyl-phosphorotrithionite, to open the cotton bolls for harvesting. Defoliation is preferred over desiccation because there is less debris and less green foliage to stain the cotton. However, defoliation is a more critical operation, and premature defoliation may cause adverse qualitative and quantitative changes in the 1 int and seed. I Thus desiccation is the more practical and more frequently used method. Cotton is mechanically harvested by two types of machines, picker-harvesters (also called spindle pickers) and stripperharvesters. Stripper-harvesters are so named because they remove not only cotton bolls but excessive amounts of field residue as well. The quantity of cotton residue arriving at the gin depends on the machine used for harvesting and the chemical harvest aid. The desiccant/stripper-harvesting approach sends the most field residue to the gin, whereas the defoliant/ picker-harvesting approach provides the least amount of residue.. A defoliant/stripper harvest would most likely contain more residue than a desiccant/picker harvest. Availability of residue for conversion at the gin varies with local harvesting approaches. 


\subsubsection{Resource Distribution}

The two major foci of cotton production in the United States are the southwest region and the south-central region, with greater acreage devoted to cotton production in the latter (see Fig. 1.1). For example, a threestate area in the south-central region (Arkansas, Mississippi, and Texas) accounted for $64 \%$ (approximately $7 \mathrm{million}$ acres) of the land harvested for cotton in 1976 and $50 \%$ ( 5.3 million bales) of 1976 cotton production. 3 . Only 13\% of the 1976 cotton acreage was in Arizona and California, but these two states generated $32 \%$ of the 1976 cotton crop. Thus cotton production is more widespread in the south but more productive in the west.

Because of such regional variability the analysis concentrates on cotton production in Arkansas, Mississippi, and Texas. Approximately

1.6 million tons of cotton gin residue were generated by these three states in 1976 (Table 1.1). This residue accounted for $50 \%$ of the total cotton gin residues generated in the United States. These figures were calculated from lint yield using a ratio of $1: 1.24$, lint:cotton gin residue (assuming stripper-harvesting), on a dry weight basis. 4 Stripper-harvesting leaves approximately 0.75 ton of cotton residue per acre in the field.5, 6 Total removal of all residue would increase the total residue production for the three states by 5.2 million tons but would greatly increase soil erosion.

These three cotton-producing states contain very productive soils, so they are ideal for evaluating the effects of crop removal on soil and environment. Although the environmental impacts of residue removal from the field are a concomitant of processing it, cotton ginning residue should be considered a field residue rather than a process residue because of the variation in harvesting options, the degree of processing, the scale of the industry, and the composition of the residue.

Table 1.1. Cotton Lint and Gin Residue Production and Energy Value of Residues

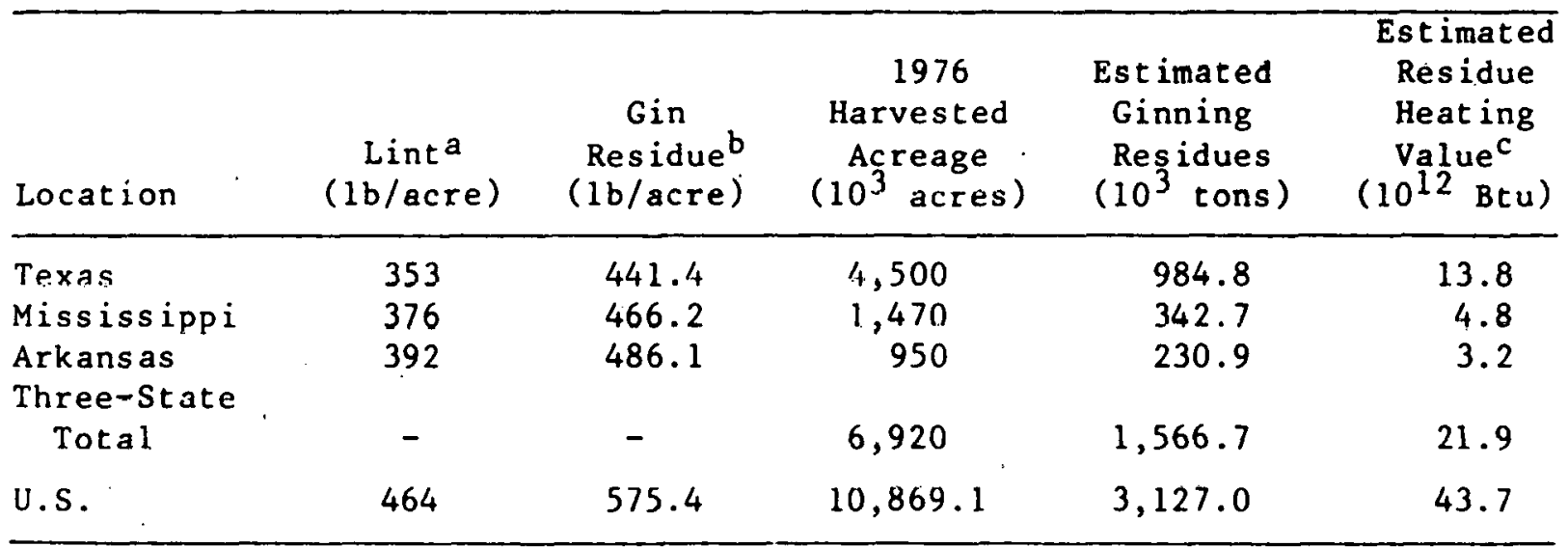

${ }^{\text {Data }}$ for $1976 . .^{3}$

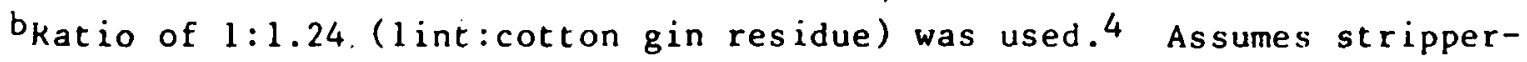
harvested.

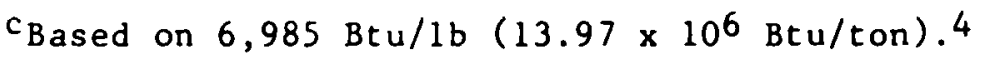




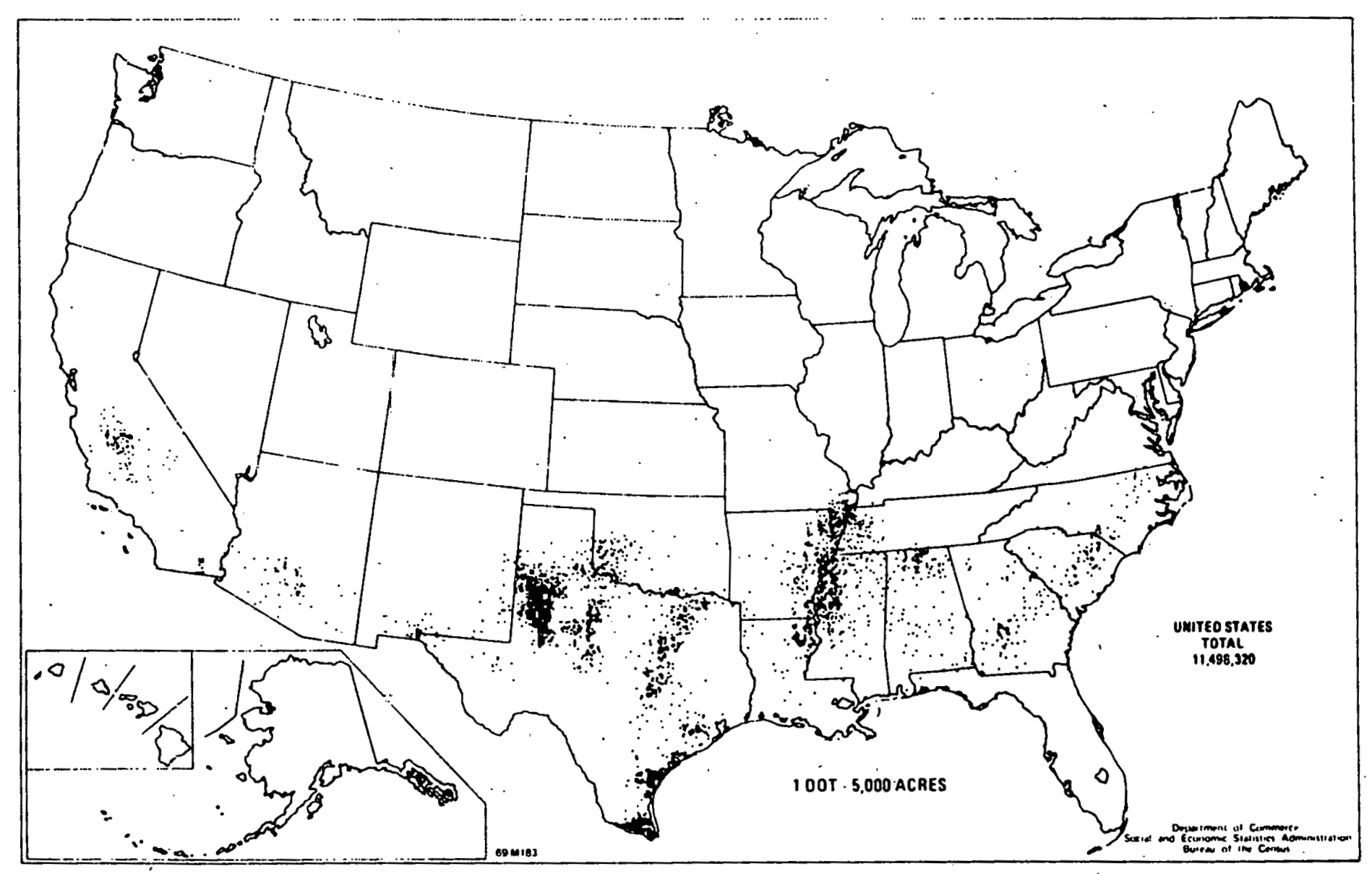

$\boldsymbol{\omega}$

Fig. 1.1 Cotton Harvested, 1969 


\subsection{DESCRIPTION OF MODEL SYSTEM}

\subsubsection{System Description}

Cotton produced in the U.S. is ginned at plants located throughout the cotton growing areas. Ginning gives. rise to three distinct products: lint (cotton fibers), cottonseed, and ginning residues, which consist of leaves., sticks, stems, hulls, soil, and motes.4,7 Two of the products, lint and cottonseed, are marketable; the ginning residues are usually disposed of as wastes. Residue production per bale typically ranges between 98 lb for picker-harvested mid-south cotton and $750 \mathrm{lb}$ for Texas stripper-collected cotton. 8

The seed cotton must be dried at the plant before it can be ginned. The two primary energy sources used in cotton lint drying: are natural gas and propane, and drying one bale typically requires $430,000 \mathrm{Btu}, 9$ though the energy requirements for drying vary greatly with environmental conditions and drier design. 10

Designs of systems for recovering gin residues and incinerating them to provide energy for drying have been reported recently by several authors.11-14 The heat exchange efficiencies range from a low of approximately $10 \%$ to a high of approximately $40 \%$. Researchers at the U.S. Cotton Ginning Research Laboratory have developed a system with $30 \%$ heat-exchanger efficiency. 12 This system provided sufficient heat recovery for processing rates of 6 to 30 bales per hour, which spans production capacities for most cotton gins in the U.S. Thus self-sufficiency at $30 \%$ heat recovery can be expected for most ginning operations.

The dry-basis fuel values of cotcon gin residues per bale are given in Table 1.2. The fuel values are typical of mid-south spindle-picked and Texas stripper-harvested residues.: The per-pound fuel values for the two

Table 1.2. Type and Quantity of Ginning Wastes and Their Fuel Values Obtained from Mississippi Delta Spindle-Picked Cotton and Texas High Plains Stripper-Harvested Cotton per 500 Pounds of Lint Ginned

\begin{tabular}{|c|c|c|c|c|c|c|}
\hline \multirow[b]{2}{*}{ Type of Waste } & \multicolumn{3}{|c|}{ Spindle-Picked } & \multicolumn{3}{|c|}{ Stripper-Harvested } \\
\hline & $\begin{array}{c}\text { Quant ity } \\
\text { (1b) }\end{array}$ & $\begin{array}{c}\text { Mo isture } \\
\text { Content } \\
(x)\end{array}$ & $\begin{array}{l}\text { Fuel } \\
\text { Valuéb } \\
\text { (Btu) }\end{array}$ & $\begin{array}{c}\text { Quantity } \\
\text { (1b) }\end{array}$ & $\begin{array}{c}\text { Moiature } \\
\text { Conlent } \\
(z)\end{array}$ & $\begin{array}{l}\text { Fuel } \\
\text { Valueb } \\
\text { (Btu) }\end{array}$ \\
\hline Leaf & 21 & 12 & 144,800 & 100 & 11 & 696,700 \\
\hline Sticks, Stems, and Hulls & 35 & 16 & 231,000 & 570 & 12 & $4,111,400$ \\
\hline Motes and Lint-Cleaner Waste & 42 & 11 & 289,900 & 30 & 10 & 209,500 \\
\hline All types & 98 & - & 675,700 & 700 & - & $5,017,600$ \\
\hline
\end{tabular}


harvesting systems are within $5 \%$ of each other (mid-south fuel value 6,895 Btu/lb; Texas fuel value $7,168 \mathrm{Btu} / 1 \mathrm{~b})$, and the mean fuel value $(7,032$ Btu/lb) can be used as representative. From these data it does not appear that the gin residue from spindle-picking systems will meet the average $430,000 \mathrm{Btu} / \mathrm{bale}$ required for drying seed cotton $(30 \%$ of $657,700 \mathrm{Btu} / \mathrm{bale}$ is $207,710 \mathrm{Btu})$. But gin residues from stripper harvest systems will provide more heat than the amount necessary for drying. A recent study of seed cotton drying in Arkansas indicates an average fuel consumption of $175,000 \mathrm{Btu} / \mathrm{bale}$ with a range of 71,000 to $380,000 \mathrm{Btu} / \mathrm{bale}$, whereas a similar study on a California dryer found fuel consumption to range from 329,000 to 406,000 Btu/bale. 15 Thus it is very difficult to estimate fuel requirements for drying, but current research indicates that gin residue will on the average be more than sufficient for seed cotton drying. Typical ratios of cotton gin residue to lint reported by various authors are given in Table 1.3. For this study stripper-harvested cotton arrives at the gin with an average residue/ lint ratio of 1.25 .

\section{2 .2 Equipment}

The model system proposed for seed cotton drying is simple and consists of three unit operations: separation, combustion, and heat transfer. This system does not have a gas scrubber on the incinerator, so a worst-case residual estimate can be provided and the most economical design can be used to evaluate the conversion technology. Thus only two major equipment requirements exist for the system: an incinerator with feeder and heat recovery unit.

\subsubsection{Energy and Material Flows}

The operating material and energy flows for the system are shown in Fig. 1.2 and Table 1.4. The plant and processing capacities are typical of the industry; the residue production level (750 lb per 500-1b bale stripperharvested cotton) was selected so that sufficient residue for combustion will be realized.

Iable 1.3. Diy Weight Relationship Between Cotton Gin Residue and Lint

\begin{tabular}{|c|c|c|}
\hline $\begin{array}{l}\text { Harvesting } \\
\text { Approach }\end{array}$ & $\begin{array}{c}\text { Residue/Lint } \\
\text { Ratio }\end{array}$ & Source \\
\hline Picker (spindle) & 0.30 & $\begin{array}{l}\text { Moore and McCaskill, } 16 \\
\text { Pend leton, } 17 \text { McCaskill } \\
\text { and Wesley } 12\end{array}$ \\
\hline Stripper & 1.00 & Larson et al. 18 \\
\hline Stripper & 1.24 & Griffin ${ }^{4}$ \\
\hline Stripper & 1.50 & $\begin{array}{l}\text { Moore and McCaskill, } 16 \\
\text { Pend leton, } 12 \text { McCaskill } \\
\text { and Wesley } 12\end{array}$ \\
\hline Stripper & 1.25 & Cotton Residue Model \\
\hline
\end{tabular}




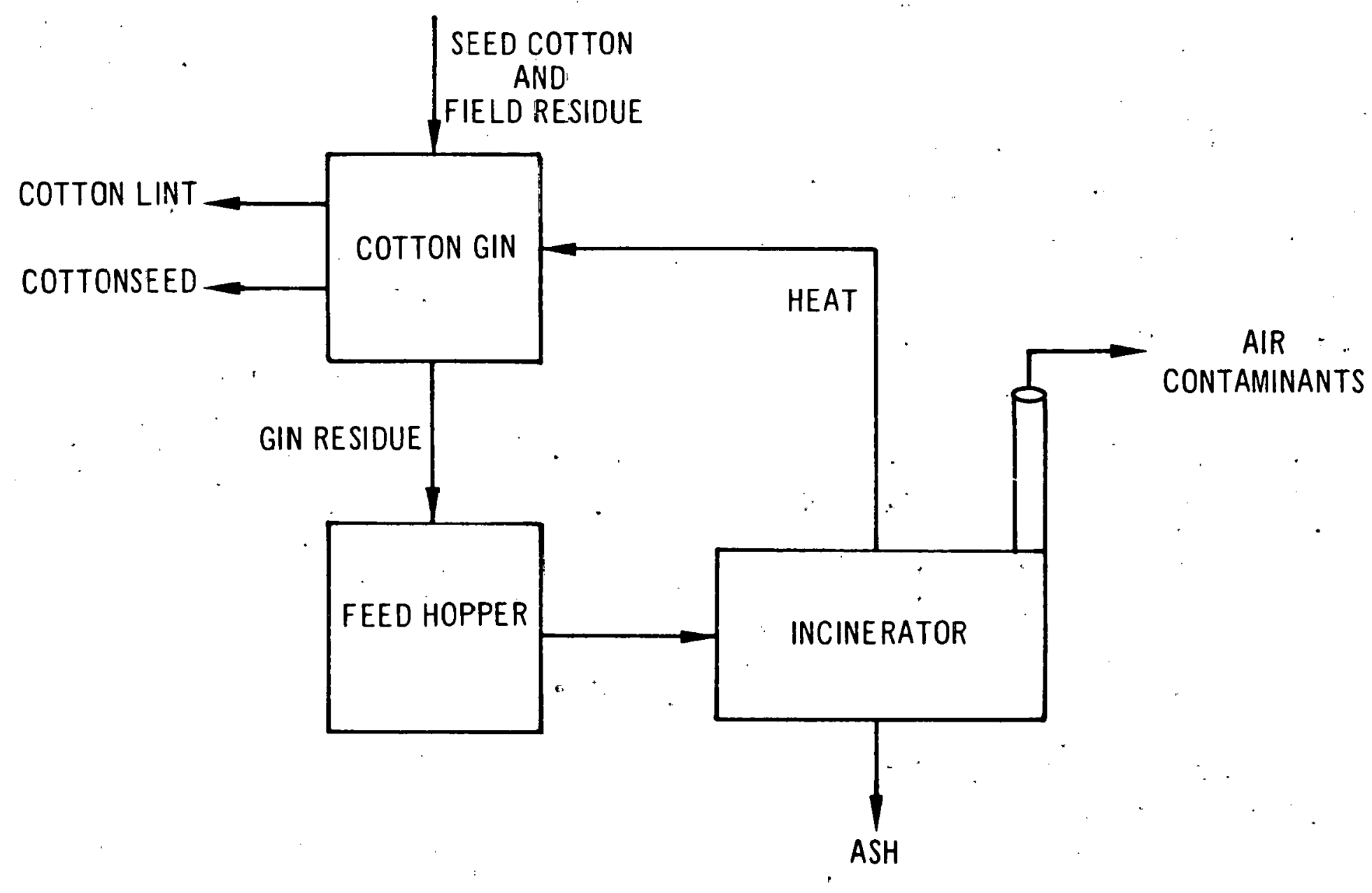

Fig. 1.2. Flow of Energy and Material in the Cotton Residue Combustion System 
Table 1.4. Material and Energy Flows for Cotton Residue Combustion System

\begin{tabular}{|c|c|c|}
\hline System Variable & Material Flow & Energy Flow \\
\hline Plant Capacity & $20,000 \mathrm{Bales} /$ Year & - \\
\hline Processing Rate & $20 \mathrm{Bales} / \mathrm{Hour}$ & $\begin{array}{l}430,000 \text { Btu/Bale } \\
\text { (drying requirement) }\end{array}$ \\
\hline Residue Feed Rate ${ }^{b}$ & $15,0001 \mathrm{~b} /$ Hour & $\begin{array}{l}7,032 \mathrm{Btu} / 1 \mathrm{~b} \\
\text { (heat value) }\end{array}$ \\
\hline $\begin{array}{l}\text { Heat Exchange } \\
\text { Efficiency }\end{array}$ & & $30 \%$ \\
\hline
\end{tabular}

assuming $1,000 \mathrm{hr} / \mathrm{yr}$ operation.

b Corresponding to $750 \mathrm{lb}$ of residue per bale of stripper-harvested cotton.

In summary, the model system considered here is of an average size for the industry, assuming seed cotton has been stripper-harvested and that no environmental control technology has been used during conversion.

\subsection{ENVIRONMENTAL DATA}

\subsubsection{General Soil Effects}

Total removal of residues from cotton, corn, and wheat crops has the same ultimate effect on the soil although the rate will vary because of crop root system, plant physiology, climatic conditions, and soil properties. Soil destruction begins with the first harvest of residue because the soil is completely exposed to water and wind. Brady 19 reports that wischmeir and Mannering found that removing residues increased runoff from 0.52 inches to 0.98 inches on 678 plot-years of corn. When residues are removed, the raindrop effect destroys surface soil structure, causing puddling, decreased water infiltration, soil compaction, reduced porosity, and a loss of organic matter. In wheat and cotton growing areas, wind takes over after the soil has dried. The wind sorts the surface material, blowing away the fines and leaving only the semisterile skeletal matter. 20

Organic matter acts as a binding agent to develop and maintain soil structure, by maintaining good tilth, increasing infiltration, maintaining soil porosity, and acting as a counter force against soil compaction.19,21 Organic matter aiso serves as a storehouse for nutrients, increases cation and anion exchange capacity, and chelates micronutrients, protecting plants from potentially toxic concentrations.19,21-23 In high-organic-matter soils this material releases approximately 40-80 lb/acre of nitrogen for crops per year.22,23 Removal of all residues from fields where corn was grown continuously during a period of 18 years resulted in a $15,000 \mathrm{lb} /$ acre decrease in organic matter. 22 
Not all residues need to be returned to the soil to maintain organic carbon content. Larson and others 18 found that by using conservational tillage (e.g., chisel plow), $1 \%$ to $57 \%$ of the corn area in selected land resource areas of Minnesota and Iowa could have all the residues removed without losing more than 4 tons of soil per acre per year. However, these are only calculated data; the amount of residues that can be safely removed from an area depends on the soil, climatic conditions, and especially management practices such as type of tillage and fertility programs. 18

The adverse effect of removing cotton residues on the chemical properties of soil can be partially overcome by increased fertilizer application. Data discussed in this report concern only the first year that crop residues are removed. In the second crop year, fertilizer application must be increased to replace that portion of the nutrients removed by the grain, residue, and erosion. Maintaining favorable chemical properties over a period of several crop years could be more costly in terms of energy for fertilizer than the amount of energy in the residues. Unfortunately, the adverse impact on the physical properties of the soil can only be slowed down with higher fertilizer rates. It takes the continual passing of crop residues through the soil and being transformed into organic matter to stop the deterioration of soil physical properties.21,23

\subsubsection{Some Aspects of Cotton Residue Removal}

Table 1.5 shows the inputs needed for cotton production in West Texas, and Table 1.6 shows the nutrients removed with each cotton crop. The harvesting of cotton leaves 0.75 ton of residue in the field per acre and removes 0.25 ton/acre of residue that will become cotton gin wastes.4,5 Even with application of nitrogen, phosphorus, and potassium in fertilizer programs, total removal of all cotton residue will adversely affect the soil. Repeated removal of calcium, magnesium, sulfur, and micronutrients will result in a decrease in the supplies of these elements in the soil, and chemical fertilizers will be needed to replace them.

Wind and water erosion are extremely important hazards in the areas where cotton is grown. No specific data were discovered on cotton yield reduction because of wind erosion, but Lyles 20 found annual reductions in wheat of $0.17-2.52$ bushels/acre and annual reductions in grain sorghum of 0.22-2.69 bushels/acre in West Texas. Thus the environmental impact associated with crop residue removal is a serious constraint to utilization of this biomass resource.

\subsubsection{Operating Residuals}

During the combustion of cotton residues at a gin, there are three major environmental prohlems: boiler ash and olog, air emissions, and wasce heat. Cotton residue contains on the average $12 \%$ noncombustible material. 15 This amounts to 240 ib of 801 id waste (ash) per ton of residue burned.

Air pollution from the process has been estimated from emissions data for the burning or incineration of similar organic materials. Table 1.7 gives some representative air emission values for the combustion of various 
Table 1.5. Inputs Needed to Obtain a Cotton Yield of 1,500 Pounds per Acre of Lint and Seed

$\therefore i \therefore$

\begin{tabular}{lcc}
\hline & $\begin{array}{c}\text { Input } \\
\text { per Acre }\end{array}$ & $\begin{array}{c}\text { Input } \\
\text { per Ton of } \\
\text { Residue } \\
\text { Removed }\end{array}$ \\
\hline Nutrients & & \\
Nitrogen (1b) & 82.0 & 328 \\
Phosphorus (1b) & 13.4 & 53.6 \\
Potassium (lb) & 21.0 & 84 \\
Seeds (1b) & 25.0 & 100 \\
Pesticides (1b) & 11.1 & 44.4 \\
Gasoline (gal) & 8.4 & 33.6 \\
Diesel Fuel (gal) & 15.9 & 63.6 \\
L.P. Gas (gal) & 2.2 & 8.8 \\
\hline
\end{tabular}

Data sources:- refs. $5,24,25$.

Table 1.6 Nutrients and Mineral Matter Removed by Cotton Cropa

\begin{tabular}{|c|c|c|c|c|c|c|c|c|}
\hline \multirow[b]{3}{*}{ Element } & & \multirow{3}{*}{\multicolumn{2}{|c|}{. }} & \multirow{2}{*}{\multicolumn{3}{|c|}{$\frac{\text { Lint and Seed }}{\mathrm{Lb}}$}} & \multicolumn{2}{|c|}{ Residue } \\
\hline & & & & & & & $\overline{L b}$ & $\mathrm{Lb}$ \\
\hline & & & & $\therefore$ & per Acre & per Ton & per Acre & per Ton \\
\hline Nitrogen & & & . & & 40.1 & 40.1 & 34.8 & 34.8 \\
\hline Phosphorus & & & & & 8.9 & 8.9 & 4.5 & 4.5 \\
\hline Potassium & & & & & 12.5 & 12.5 & 29.4 & 29.4 \\
\hline Calcium & & & & & 1.8 & 1.8 & 27.7 & 27.7 \\
\hline Magnesium & & & & & 3.6 & 3.6 & 8.0 & 8.0 \\
\hline Sulfur & & & & . & 1.8 & 1.8 & - & - \\
\hline Copper & & & & & 0.06 & 0.06 & - & - \\
\hline Manganese & & & & & 0.11 & 0.11 & - & . \\
\hline Zinc & & & & & 0.32 & 0.32 & - & - \\
\hline Mineral Matte & & & & & - & - & 84.0 & 84.0 \\
\hline
\end{tabular}

Data sources: refs. $21,26,27$.

${ }^{a}$ An assumption was made that a linear relationship exisced between crop yield and nutrient uptake; therefore data were adjusted for a yield of 1,500 pounds/acre. 
biomass sources. Regarding air quality, it should be noted that since defoliants or desiccants are applied close to harvest, these chemicals may also be present in the stack gases. However, it is not now possible to quantify the amounts of such chemicals emitted.

Waste heat results from the operation both because of inefficient heat transfer and also because of excess residue that is disposed of by incineration. Approximately $13 \times 10^{6} \mathrm{Btu}$ of heat are lost into the air per ton of residue incinerated. Much of this heat could be utilized by developing an alternative system such as the one proposed by Lalor and Smith. 29 They describe an $800-\mathrm{kW}$ power plant in which both heat for drying and electricity for ginning would be supplied. The total estimated cost for the system is $\$ 545,000$, which includes an incinerator $(\$ 125,000)$, a waste heat boiler $(\$ 40,000)$, a turbine generator $(\$ 85,000)$, miscellaneous equipment $(\$ 85,000)$, and building, Coundalious and inscallation $(\$ 210,000)$.

The operating residuals generated by cotton gin residue combustion have been tabulated per $10^{12} \mathrm{Btu}$, in Table 1.8 .

\subsection{ECONOMIC DATA}

\subsubsection{Capital Costs}

The incineration system for combustion of cotton gin residues and generation of process heat requires two material components: a multiplechamber incinerator with a gas pilot and a heat recovery unit. On the basis of a processing rate of 20 bales per hour $\left(8.6 \times 10^{6} \mathrm{Btu} / \mathrm{hr}\right), 1,000 \mathrm{hr}$ per year operation, and a $30 \%$ heat recovery efficiency, approximately 2 tons per hour of cotton gin residue $\left(14.1 \times 10^{6} \mathrm{Btu} / \mathrm{ton}\right)$ will have to be incinerated.

Table 1.7. Air Emissions From Combustion of Biomass and Related Materials

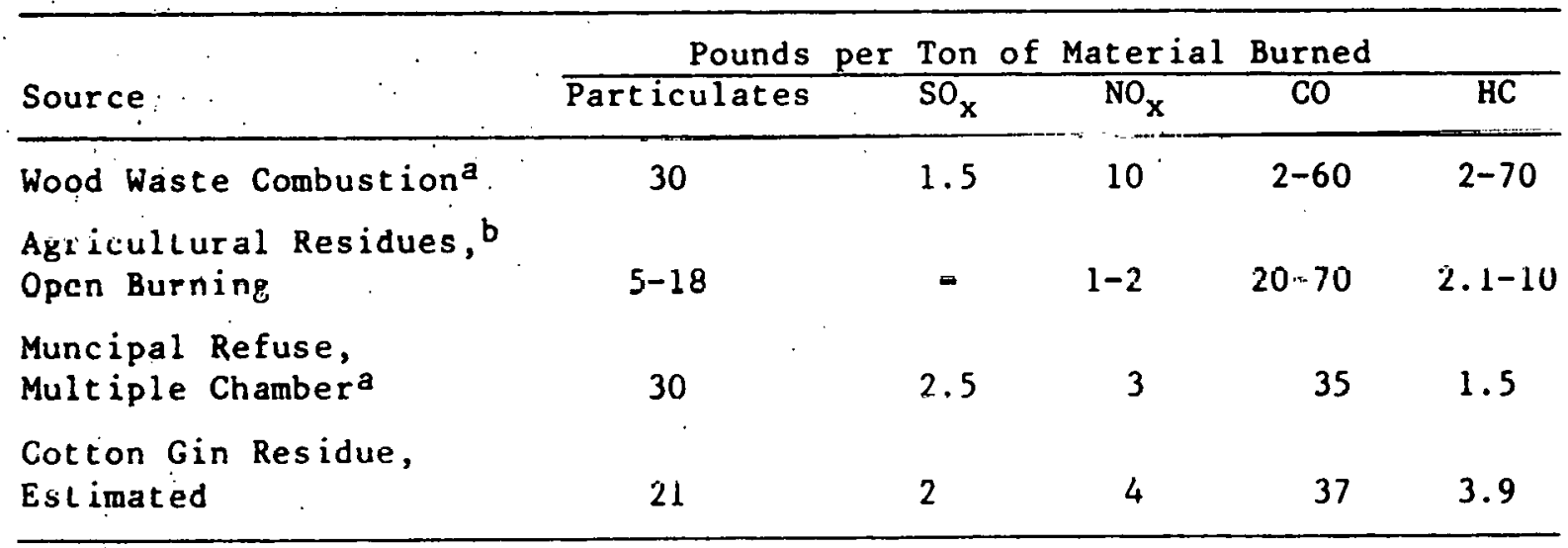

asource: ref 28 .

bSource: ref 29 . 
Table 1.8 Residuals Data for Combustion of Cotton. Residues

\begin{tabular}{lcc}
\hline \multicolumn{1}{c}{ Residual } & $\begin{array}{c}\text { Gross Residual } \\
\text { per } 10^{12} \text { Btu } \\
\text { Input }\end{array}$ & $\begin{array}{c}\text { Gross Residual } \\
\text { per } 10^{12} \text { Btu } \\
\text { End-Use } \\
\text { Energy }\end{array}$ \\
\hline Particulates & 744 & 9,150 \\
$\mathrm{SO}_{2}$ & 69 & 850 \\
$\mathrm{NO}_{\mathrm{x}}$ & 142 & 1,750 \\
$\mathrm{CO}^{\mathrm{N}}$ & 1,313 & 16,150 \\
Hydrocarbons, & 138 & 1,700 \\
Slag, ash & 8,720 & 104,640 \\
\hline
\end{tabular}

The cost of a $1,200-1 b / h r$ incinerator with feeder was $\$ 50,000$ in 1977.31 Using a cost-scaling approach known as the "six-tenths factor" method, 32 the increased cost for the larger unit $(4,000 \mathrm{lb} / \mathrm{hr})$ was calculated as follows:

$$
L=s \times\left(C_{L} / C_{S}\right)^{0.6}
$$

where:

$$
\begin{aligned}
& \mathrm{L}=\text { cost of the larger unit } \\
& \mathrm{S}=\text { cost of the smaller unit } \\
& \mathrm{C}_{\mathrm{L}}=\text { capacity of the larger unit } \\
& \mathrm{C}_{\mathrm{S}}=\text { capacity of the smaller unit }
\end{aligned}
$$

Therefore $\$ 50,000 \times(4,000 / 1,200) 0.6=\$ 50,000 \times 2.059=\$ 102,967$. The cost of a heat recovery unit is $100 \%$ the cost of the incinerator. Labor on the $1,2001 \mathrm{~b} / \mathrm{hr}$ unit was $4 \%$ of the total cost, and overhead and profit came to $10 \% .30$ It is assumed that these costs would be proportionally the same for the larger unit. The capital cost data are summarized in Tables 1.9 and 1.10. The total estimated capital cost. for this system in 1972 dollars is $\$ 158,093$.

\subsubsection{Operating and Maintenance Costs}

Annual operating and maintenance costs (in 1978 dollars) have been computed as follows for the incineration and drying sytem:

- Labor cooperation and maintenance $(0.1 \mathrm{hr} / \mathrm{bale}$ at $\$ 10 / \mathrm{hr}) \quad \$ 20,000$

- Supervision ( $20 \%$ of labor)

$$
4,000
$$

- Overhead (60\% of labor plus supervision)

- Parts $(\$ 1,000 /$ year $)$

- Total

Operating and maintenance costs, in 1972 dollars, would be $\$ 26,263$. 
Table 1:9: ' Capital Costs for Model System for Model System for Combustion. of Cotton Gin Residues for Process Heat

Component (Industrial Sector)

Cost in

1978 Do.llars

Incinerator with Feeder (Plumbing and Heating Equipment)

Heat.Recovery Unit (Plumbing and Heating Equipment)

95,760

95,760

14,414

Transportation

Labor for Installation ( $634 \mathrm{hr}$ at $\$ 13 / \mathrm{hr})$

8,242

Overhead and Profit

Ali Components

20,543

234,769

Table 1.10. Capital Expenditures and Materials Summary for Model System for Combustion of Cotton Gin Residues for Process Heat

\begin{tabular}{|c|c|c|c|c|}
\hline & 1978 Dollars & Deflat or & 1972 & Dollars \\
\hline $\begin{array}{l}\text { Total Capital Cost } \\
\text { Malerials } \\
\text { Transportation } \\
\text { Construction Labor } \\
\text { Prof it and Overhead }\end{array}$ & $\begin{array}{r}234,769 \\
191,319 \\
14,414 \\
8,242 \\
20,593\end{array}$ & $\begin{array}{l}1.485 \\
1.485 \\
1.485 \\
1.485 \\
1.185\end{array}$ & $\begin{array}{l}15 \\
12 \\
1\end{array}$ & $\begin{array}{r}58,093 \\
28,969 \\
9,707 \\
5,550 \\
13,867\end{array}$ \\
\hline $\begin{array}{l}\text { Annual system } 10^{12} \text { Btu Output } \\
\text { Total Capilal Cost } / 10^{12} \text { Annual Btu }\end{array}$ & & $\begin{array}{r}.8 .6 \\
18.383\end{array}$ & $\begin{array}{l}10^{-3} \\
106\end{array}$ & \\
\hline Number of Years to Construct Facility & .. & $\because$ & & \\
\hline Expected Life of Facility (yr) & & & & . \\
\hline Man Years to Construct Facility & & & .317 & \\
\hline Man Years/10 12 . Btu Annual Output & . & & .9 & \\
\hline Estimated Land Use & & & & \\
\hline
\end{tabular}




\subsection{SUMMARY OF FINDINGS}

On the basis of $10^{12}$ Btu of energy output by the system, the material, energy, residual, and cost inputs and outputs for the system are summarized in Table 1.11. It would require 116 such systems to substitute for $10^{12}$ Btu of natural gas or other appropriate fuel. 
Table 1.11. Cotton Gin Residue Combustion Input/Output Stmmary

\begin{tabular}{|c|c|c|}
\hline System Variables & $\begin{array}{c}\text { Inputs } \\
\left(\text { per } 10^{12} \mathrm{Btu}\right)\end{array}$ & $\begin{array}{c}\text { Outputs } \\
\text { (per } 10^{12} \text { Btu) }\end{array}$ \\
\hline $\begin{array}{l}\text { Size } \\
\text { Processing capacity - } 20,000 \\
\text { bales per year } \\
\text { Annual fuel requirement - average } \\
\text { of } 430,000 \text { Btu/bale or } 8.6 \times 10^{9} \\
\text { Btu per year at capacity } \\
\text { Description } \\
\text { Cotton residue incinerator } \\
\text { with a natural gas - fired } \\
\text { burner for start-up or auxil- } \\
\text { liary heating coupled with } \\
\text { a heat exchanger for drying } \\
\text { seed cotton } \\
\text { Components } \\
\text { Incinerator } \\
\text { Gas burner } \\
\text { Heat exchanger (30\% efficiency) } \\
\text { Fan } \\
\text { Exhaust air scrubber (optional) } \\
\text { Cyclone separator (should already } \\
\text { be at plant) } \\
\text { Major Environmental Problems } \\
\text { Boiler ash/slag disposal } \\
\text { Air emissions } \\
\text { Waste heat }\end{array}$ & $\begin{array}{l}\frac{\text { Fuel }}{2.326} \times 10^{6} \text { bales will require } \\
10^{12} \text { Btu for drying and } 116 \mathrm{gins} \\
0.872 \times 10^{6} \text { tons of cotton residue } \\
\text { (stripper-harvested) will be at } \\
\text { mill (heating value } 14.1 \times 10^{6} \\
\text { Btu/ton) } \\
\text { Total energy content of cotton } \\
\text { residue } 12.3 \times 10^{12} \text { Btu } \\
\text { Energy required for drying ( } 30 \% \\
\text { efficiency) } 3.689 \times 10^{12} \mathrm{Btu} \\
\text { Water } \\
\text { None }\end{array}$ & $\begin{array}{l}\text { Air Pallutants } \\
\text { Particulates: } 9.15 \times 10^{3} \text { tons } \\
\mathrm{SO}_{\mathrm{x}}: 0.85 \times 10^{3} \text { tons } \\
\mathrm{NO}_{\mathrm{x}}: 1.75 \times 10^{3} \text { tons } \\
\mathrm{CO}: 16.15 \times 10^{3} \text { tons } \\
\text { Hydrocarbons: } 1.7 \times 10^{3} \text { tons } \\
\text { Water Pollutants } \\
\text { None } \\
\text { Solid Waste } \\
\text { Boiler ash/slag: } 104,640 \text { tons } \\
\text { Energy } \\
\text { Effective process heat: } 10^{12} \\
\text { Btu (replaces natural gas) } \\
\text { Wastec process heat: } 11.3 \mathrm{x} \\
\text { 1012 Etu :from excess residue } \\
\text { burnec to reduce solid wastes) }\end{array}$ \\
\hline
\end{tabular}




\section{REFERENCES}

1. Mitchel1, R.L., Crop Growth and Culture, Iowa State University Press, Ames, Ia. (1970).

2. U.S. Bureau of the Census, Census of Agriculture, 1969, Vol. 5, Special Report6, Part 15, Graphic Summary, U.S. Government Printing Office, Washington, D.C. (1973).

3. U.S. Department of Agriculture, Statistical Reporting Service, Agricultural Statistics 1977, Washington, D.C.; U.S. Government Printing office (1977).

4. Griffin, A.C., Jr., Fuel Value and Ash Content of Ginning Wastes, Transactions of the ASAE, p. 156 (1976).

5. Alich, J.A., Jr., F.A. Schooley, R.K. Ernest, R. Hamilton, B.M. Louks, K.A. Miller, T.C. Veblen, and J.G. Witwer, An Evaluation of the Use of Agricultural Residues as an Energy Feedstock -- A Ten Site Survey, Vol. 2 -- Study Area Analysis, Stanford Research Institute, Menlo Park, Calif. (July 1977).

6. Alich, J.A., F.A. Schooley, R.K. Ernest, K.A. Miller, B.M. Louks, T.C. Veblen, J.G. Witwer, and R.H. Hamilton, Feasibility of Utilizing Crop, Forestry, and Manure Residues to Produce Energy, Fuels and Energy from Renewable Resources, Academic Press, New York (1977).

7. Oursbourn, C.D., W.A. LePori, R.D. Lacewell, K.Y. Lam, and O.B. Schacht, Energy Potential of Texas Crops and Agricultural Residues, Texas Agricultural Experiment Station, College Station, Texas (Feb. 1978).

8. Griffin, A.C., Fuel Value of Gin Wastes, Cotton Ginners Handbook, Agriculture Handbook No. 53, U.S. Department of Agriculture (1977).

9. Holder, S.H., and 0.L. McCaskili, Costs of Electric Power and Fuel for Driers in Cotton Gins, Arkansas and Mis6ouri, USDA-ERS-138, U.S. Government Printing Office (1963).

10. Griffin, A.C., Cotton Moisture Control, Cotton Ginners Handbook, Agriculture Handbook No. 53, U.S. Department of Agriculture (1977).

11. Lalor, W.F., J.K. Jones, and G.A. Slater, Performance Test of HeatRecovering Gin-Waste Incinerator, Cotton Inc., Agro-Industrial Report 3(2), Raleigh, N.C. (1976).

12. McCaskil1, O.L., and R.A. Wesley, Energy from Cotton Gin Waste, Ginner's Journal and Yearbook (1976). 
13. McCaskill, O.L., R.V. Baker, and R.A. Wesley, Collection and Disposal of Gin Waste, Cotton Ginners Handbook, Agriculture Handbook No. 53, U.S. Department of Agriculture, (1977).

14. Cotton Ginners Handbook, Agricultural Handbook No. 53, U.S. Department of Agriculture (1977).

15. Lalor, W.F., Use of Ginning Waste as an Energy Source, Fuels and Energy from Renewable Resources, D.A. Tillman, K.V. Sarkanen, and L.L. Anderson, (eds.), Academic Press, New York (1977).

16. Moore, V.P., and 0.,L. McCaskill, Control of Cotton Ginning Wastes, Environmental Health. Series -- Air Pollution, Department of Health, Education, and Welfare, Cincinnati, Ohio (1967).

17. Pendelton, A.M., Control and Disposal of Cotton Ginning Wastes, Environmental Health Series -- Air Pollution, Department of Health, Education, and Helfale, Cilluimali, Ohiv (1967).

18. Larson, W.E./, R.F. Holt, and C.W. Carlson, Residues for Soil Conservation, Crop Residue Management Systems, W.R. Oschwald (ed.), Am. Soc. of Agronomy spec. Pub. No. 31, pp. 1-15 (1978).

19. Brady N.C., The Nature and Properties of Soils, Macmillan, New York (1974).

20. Lylés, L., Possible Effects of Wind Erosion on Soil Productivity, Journal of Soil and Water Conservation, 30(6), 279-283 (1975).

21. Tisdale, S.L., and W.L. Nelson, Soil Fertility and Fertilizers, Macmillan, New York (1975).

22. Adams, E.P., L.A. Derscheid, L.0. Fine, and M.S. Argabright, Do You Really Want to Remove Crop Residue? South Dakota Agriculture Experiment Station, Brookings, S.D. (1978).

23. Alison, F.E., Soil Organic Matter and its Role in Crop Production, Elsevier, Amsterdam (1973).

24. VanWinkle, T.L., J. Edleanu, E.A. Prosser, and C.A. Walker, Cottón Versus Polyester, American Scient ist 66, 280-290 (May-June 1978).

25. National Academy of Sciences, Commission on Natural Resources, Environmental Studies Board, Cotton: An Assessment of Current and Future Pest Management (Sept. 1974).

26. Carman, W.H., D.A. Williams, A.W. Tenny, and E.T. York, Jr, Our Land and Its Care, Fertilizer Institute, Washington, D.C. (1952).

27. Morrison, F.B., Feeds and Feeding, Morrison Publishing Co., Clinton, Ia. (1959). 
17

28. Sittig, M., Environmental Sources and Emissions Handbook, Noyes Data Corp., Park Ridge, N.J., PP. 519-521 (1975).

29. Chi, C.T., and D.L. Randers, Source Assessment: Agricultural Open Burning -- State of the Art, EPA-600/2-77-107a. (July 1977).

30. Lalor, W.F., and M.L. Smith, Use of Ginning Waste as an Energy Source, Food, Fertilizer, and Agricultural Residues, Ann Arbor Science Press, Ann Arbor, Mich., Pp. 446-464 (1977).

31. Godfrey, R.S., Means Cost Data, Robert Snow Means, Inc., Duxbury, Mass. (1977).

32. Perry, R.H., and C.H. Chiton, Chemical Engineers Handbook, McGrawHill, New York (1973). 
18.

\section{THIS PAGE}

\section{WAS INTENTIONALLY \\ LEFT BLANK}


2 COGENERATION FROM BLACK LIQUOR AND BARK AND WOOD RESIDUES

\section{ABSTRACT}

This section evaluates capital costs and environmental residuals of energy recovery from black 1 iquor and bark and wood residues through direct combustion to generate heat, steam, and electricity. A large integrated Kraft-process pulp and paper mill is used in the analysis to represent the most common type of U.S. mill, and data are presented on construction and operation of the mill and on the energy involved in the conversion processes. Use of black liquor and bark and wood residues for generating energy is an economically and environmentally sound practice for mills in the U.S producing pulp and paper, but it is noted that removal of residues from logging areas depletes the soil. The model system requires 4 acres for processing and storage and will dispose of wastes from a paper mill consuming 54 acres of mature trees per year of operation.

\subsection{INTRODUCTION}

\subsubsection{General System Description}

Forestry and wood manufacturing residues have been used for energy generation since old times, and several technologies have been employed to produce fuel forms from this waste material.

Cogeneration from bark and wood wastes has been proved to be a profitable technology for energy generation and safe disposal of wood manufacturing wastes. The vast amount of residues (black liquor and bark and wood refuse) yielded by the pulp and paper industries is burned by these companies to cogenerate steam, heat, and electricity. During combustion a considerable amount of residuals is released into the air, water streams, and soil. Besides polluting the environment, these residuals represent losses of capital and energy. Since pulp and paper mills demand great amounts of energy in the form of heat and electricity and also generate huge tonnages of residuals, this study is addressed to the environmental residual and capital cost evaluation of energy recovery from cogeneration with black liquor bark and wood residues.

Conversion of bark and wood residues to energy by combustion is examined here, and a model system is described for material estimates and energy flow purposes. A national scope is provided for the residues considered and the associated environmental consequences of residue utilization. Energy operating this system is given in $10^{12} \mathrm{Btu}$, and the environmental impacts of operating this model system are examined by quantifying the residuals generated, land required, water needed, and material utilized in terms of $10^{12} \mathrm{Btu}$ of energy produced.

Capital operating and maintenance cost estmates are given for the, model system on the basis of information found in the literature and obtained from personal communication. The data on costs, residuals, materials, and 
land and water requirements have been organized into the format required for the SEAS (Strategic Environmental Assessment System) computer program.

\subsubsection{Resource Characteristics}

In the manufacture of pulp and paper, several fuels are used, including fossil fuels (oil, coal, and natural gas), residues from bark and wood, and spent liquor solids. The pulp and paper industry is, in fact, the fourth largest consumer of fuels and electricity in the United States.1 In 1970 the industry consumed 1.5 Quads of energy, and in 1975 it used 1.896 Quads.2

In the past, residues were either dimped or burned, but moot of today's mills burn their residues for the cogeneration of process steam and eloctrlcity, In 1975 the milp and papor induftry consuiutd 0.830 Quads of selfgenerated and waste fuels, 2 and in 1976 the industry generated and used a total of 0.98 Quads (0.124 Quads of bark, 0.791 Quads of spent 1iquor, and 0.069 Quads of hogged fuel -- a mixture of bark, sowdust, scraps, and slabs of wood). ${ }^{3}$

Large mills are usually integrated, producing both pulp and paper, whereas smaller ones are frequently nonintegrated, producing either one or the other. Most of the paper produced in the U.S. is manufactured by integrated mills processing wood cellulose as main raw material. ${ }^{2}$ over ten different pulping processes are employed by the paper-making industry, but most of the pulp and paper produced today have been processed through the Kraft method.

The major unit operations in a pulp or paper mill are: (a) preparation (barking, chipping); (b) pulping (chemical, chemical/mechanical, mechanical); (c) heat and chemical recovery; (d) washing and bleaching; (e) stock preparation; and (f) paper and board manufacture (shept. fnrmation, mechanical water removal and drying). I The main energy-consuming operations are (b), (c), (d), and (f), and the main pollution sources are (b), (c), and (d). I

\subsection{DESCRIPTION OF MODEL SYSTEM}

\subsubsection{Technology Involved}

The Kraft process, which, as mentioned previously, is the pulping process most prevalent in the United States, is used as the basis for our model forestiy-residue conversion system (see Fig. 2.1 for a schematic of the process). In the Kraft process, wood chips are cooked for 2 to 4 hours in an alkaline solution of sodium sulfate and sodium sulfite under high temperatures and pressures $\left(350^{\circ} \mathrm{F}, 100 \mathrm{psig}\right.$ ) in order to separate the cellulose fibers from the lignin and other materials.2,4 The spent cooking liquor, known as black 1 iquor, contains the lignin and the chemicals used in the process. The liquor passes through a recovery system, and most of the chemicals are obtained and reused; the remaining lignin plus other combustible materials are solidified ( $55-65 \%$ solids) by drying. Thereafter the solidified liquor is conveyed to the furnaces/boilers and combusted to generate heat, steam, or electricity. 


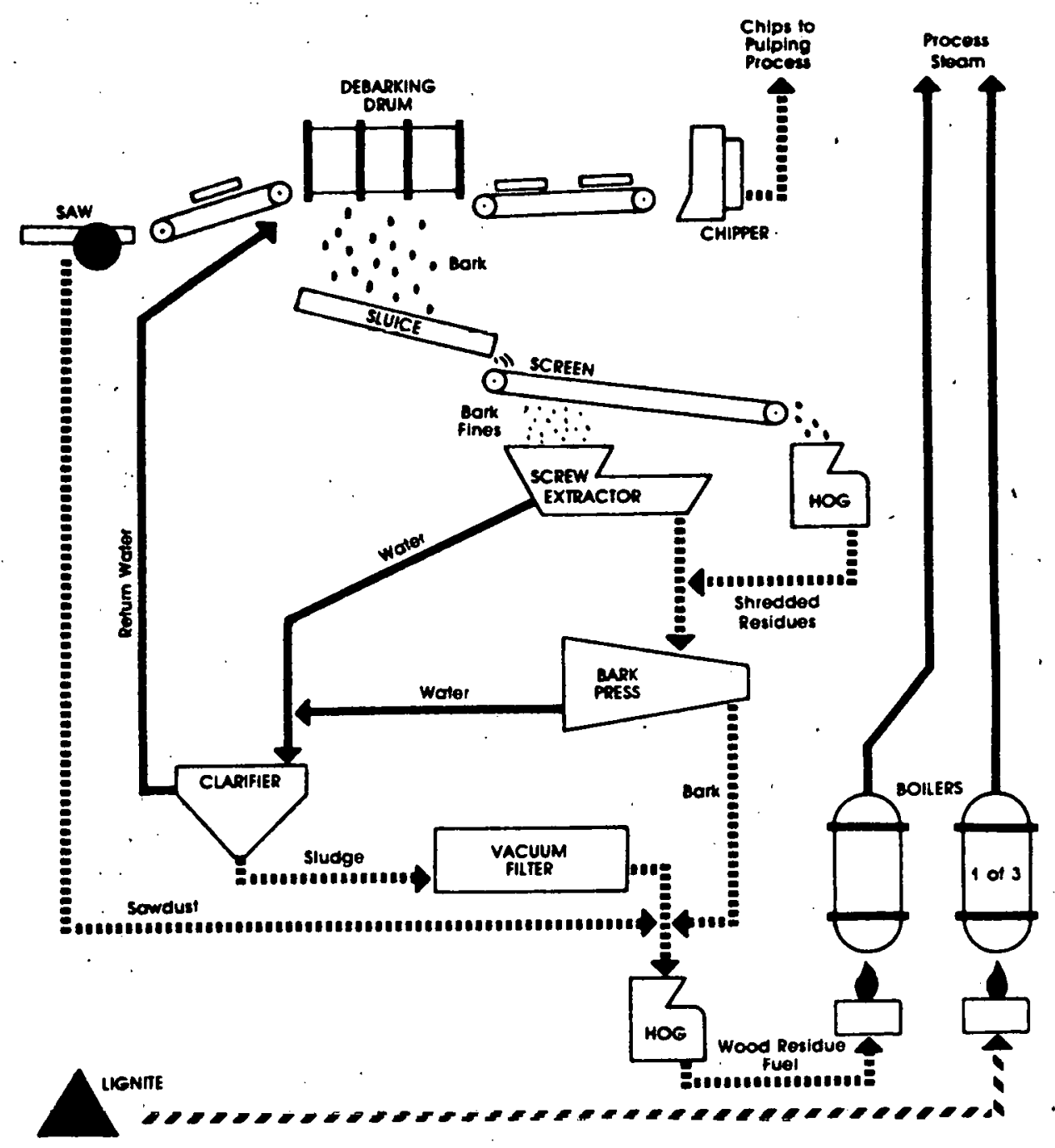

Fig. 2.1. The Kraft Process 
If $10,000 \mathrm{lb}$ of weak black liquor ( $16.5 \%$ solids) enters the recovery system, then about 987 . lb of dissolved lignin can be burned in the furnace, $14,300 \mathrm{lb}$ of steam and $2,28 \mathrm{lb}$ of $\mathrm{CO}_{2}$ are generated, and $1,9.25 \mathrm{lb}$ of water vapor and $6,494 \mathrm{lb}$ of $\mathrm{N}_{2}$ are released. ${ }^{6}$ Also during this combustion, $8,473 \mathrm{lb}$ of air and $6,359 \mathrm{lb}$ of water are introduced into the furnace boiler.6 The black liquor generated from the Kraft process in producing one bone-dry. (BD) ton of pulp has been found to contain 2,334 lb of lignin, $2571 \mathrm{~b}$ of $\mathrm{Na}_{2} \mathrm{CO}_{3}, 697$ lb of $\mathrm{NaOH}, 439$ lb of $\mathrm{Na}_{2} \mathrm{~S}$, and 12,425 lb of water. ${ }^{4}$

It has been estimated that production of a one BD ton of Kraft pulp by the batch digester process requires $325 \mathrm{kWh}$ of electric energy and $8,5001 \mathrm{~b}$ of steam at about $80 \mathrm{psig}$ (equivalent to $10.67 \times 10^{6} \mathrm{Btu}$ ) and that one ton of spent liquor solids burned in the recovery furnace releases $13.2 \times 10^{6} \mathrm{Btu} .{ }^{2}$

Arthuir D. Littlel has computed the following data concerning the production of one air-dry (AD) ( $10 \%$ moisture content) ton of Kraft pulp (= $1,800 \mathrm{BD}$ lb): the power hoiler uses 312 BD lb of bark residues plus $90 \mathrm{BD}$ 1b of wood chip residues and $3.9 \times 10^{6} \mathrm{Btu}$ of fossil fuels to produce $3,8001 \mathrm{~b}$ of steam ( $800 \mathrm{lb}$ from bark and wood chips and 3,000 $\mathrm{lb}$ from fossil fuels). In the same mill and for one $A D$ ton of pulp, 15,800 $1 \mathrm{~b}$ of steam $(12,0001 \mathrm{~b}$ from the chemical recovery system and $3,800 \mathrm{lb}$ from the boiler) in a back-pressure turbine generate $720 \mathrm{kWh}$ of electricity, of which $580 \mathrm{kWh}$ are used and $140 \mathrm{kWh}$ are credited.

In the direct combustion of black liquor, wood, and bark wastes, various types of wood burners are used: the Dutch oven, the fuel cell, the spreader-stoker, the inclined grate, and the fluidized bed. A Dutch oven with a flat grate is used in small and old operations: here the fuel is dumped through the furnace roof and burned in a cone-shaped pile on the grate. 7 In larger operations other types of furnaces and boilers are used. Fuel cell boilers are mostly used in the drying kilns of small companies and produce up to $30,000 \mathrm{lb} / \mathrm{hr}$ of steam (25 psig). The spreader-stoker system with traveling or vibrating grates is common in newly constructed plants and $c$ an be used either by small plants $(25,000 \mathrm{lb} / \mathrm{hr}$ steam rate) or by larger ones $(500,000$ $\mathrm{lb} / \mathrm{hr}$ steam rate). The inclined-grate furnace is like that used for incineration of municipal solid wastes. The fluidized-bed heat recovery system can burn wood residues containing up to $55 \%$ moisture. Because of the high mois=ture content of the bark and wood residues, the various burning processes have to spend energy to evaporate the water. Commonly, in these furnaces an auxiliary fossil fuel is also used to maintain the flame and to provide steam.

The moisture content of wood residues is the main factor that determines their economic suitability as combustion feedstocks. On the average, wood containing $50 \%$ moisture requires close to $13 \%$ of its total heat value to evaporate the water. Therefore, in order to be combusted, very moist wood material has to be dried first, and such drying requires additional use of fue 1.8 Bark residue has two main disadvantages as a fuel: an effective heating value of only about 4,000 Btu per pound because of a $50 \%$ moisture content (dry bark's heating value is about $9,000 \mathrm{Btu} / \mathrm{lb}$ ), and a lack of homogeneity (because of species, season, moisture, dirt content, etc.).9 Large quantities of air are required for complete combustion of bark residue. 
Hogged wood fuel has an average heating value of $3,850 \mathrm{Btu} / \mathrm{lb}$ at $50 \%$ moisture and possesses characteristics similar to bark residue. The heating value of solidified black liquor ( $50 \%$ moisture) is about $6,700 \mathrm{Btu} / \mathrm{lb} .^{2}$

The model selected for this study is that of an integrated mill using the Kraft process, in which black liquor and bark and wood are combusted for heat, process steam, and generation of electricity. This model represents an average U.S. pulp and paper mill. The requisite unit processes for energy. generation from black 1 iquor and bark and wood residues in the model mill are depicted in Fig. 2.2. The main operations required for residue utilization are generation of bark and wood residues, black liquor generation, drying, storage, and finally combustion.

The solidified black liquor is burned in the recovery furnace to supply heat for making high-pressure steam. 10 The high-pressure steam is used to generate electricity and low-pressure process steam. The combustible gases $\left(300^{\circ} \mathrm{F}\right)$ released from the furnace supply heat to the evaporator.

\subsubsection{Energy and Material Flows}

The material and energy flows for operation of the model system are summarized in $T a b l e ~ 2.1$, and the data give typical operating flows that could be found in an average Kraft process pulp and paper mill in the United States.

In this model mill, in addition to bark and wood residues and black liquor, fossil fuels are used to generate additional steam and electricity as follows :

Additional steam $\left(0.1 \times 10^{12} \mathrm{Btu} / \mathrm{mill}\right.$ implies $0.5 \times 10^{6} \mathrm{Btu} / \mathrm{BD}$ ton of pulp)

(a) from gas: $\left(0.35 \times 10^{6} \mathrm{Btu} / \mathrm{BD}\right.$ ton of pulp) $\times 200,000 \mathrm{BD}$ $=0.07 \times 10^{12} \mathrm{Btu} / \mathrm{yr}$

(b) from oil: (0.15 $\times 10^{6} \mathrm{BCu} / \mathrm{BD}$ con of pulp) $\times 200,000 \mathrm{BD}$ $=0.03 \times 10^{12} \mathrm{Btu} / \mathrm{yr}$

Additional electricity $\left(188 \times 10^{9} \mathrm{Btu} / \mathrm{mill} \times 0.3\right.$ by gas implies $\left(0.28 \times 10^{6} \mathrm{Btu} / \mathrm{BD}\right.$ ton of pulp) implies $0.56 \mathrm{x}$ $10^{\mathrm{i} 2} \mathrm{Btu} / \mathrm{yr} / \mathrm{mi} 1 \mathrm{l}$

\subsection{ENVIRONMENTAL DATA}

\subsubsection{Environmental Consequences of Residue Utilization}

It has been estimated that annual U.S. production of forestry residues amounts to $3.5 \times 10^{9} \mathrm{ft}^{3}$ from unused and precommercial thinning. 8 In 1970 , forest residues were estimated to be approximately 49 percent of logging wastes, 37 percent of standing biomass, and 14 percent of mill by-products. 11

Lumber, plywood, pulp, and allied industries reprocess part of the wood residues into pulp and paper, composition board, and fuels. More than 


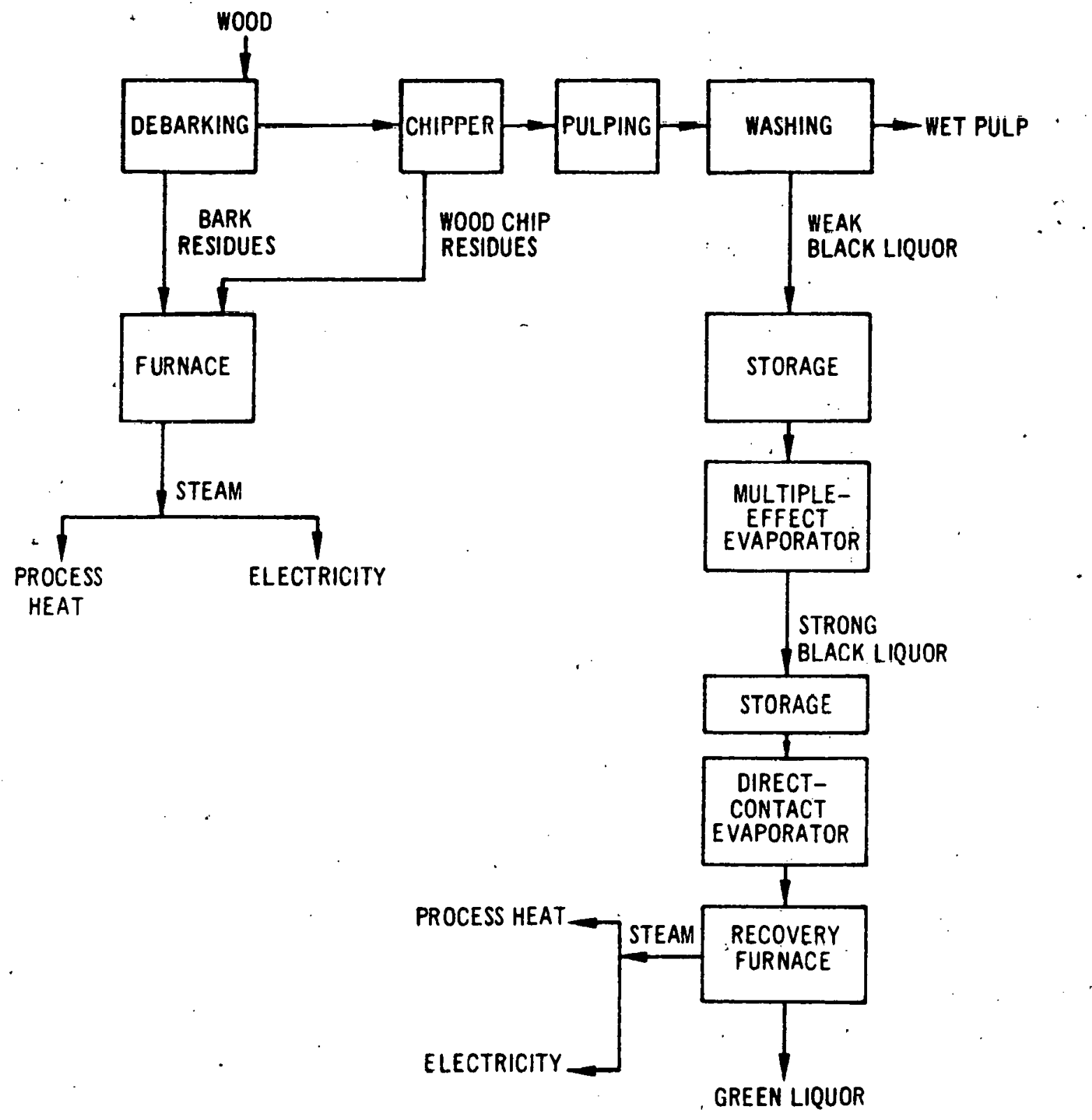

Fig. 2.2. Model Cogeneration System for Bark and Wood Residues 
Table 2.1. Material and Energy Flows for Energy Recovery from Model Residue-Conversion System

\begin{tabular}{|c|c|c|}
\hline Syatem Variable & Meterial Plow & Energy Tlou \\
\hline $\begin{array}{l}\text { Plant Capacity } \\
:\end{array}$ & $200,000 \mathrm{BD}$ cone pulp/yr & 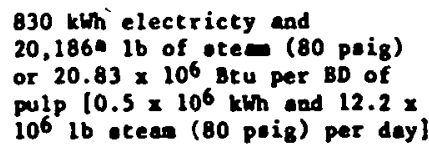 \\
\hline Procesaing Rete & 606 BD tone pulp/deyb & \\
\hline $\begin{array}{l}\text { Revidue Production } \\
\text { Race }\end{array}$ & $\begin{array}{l}360 \text { BD lb bark reaidue/BD tone of pulp } \\
80 \text { BD ib wood chip reaidue/BD tone of pulp } \\
2.75 \text { tong }(552 \text { colide) black liquor/BD tone of pulp }\end{array}$ & $\begin{array}{l}18 \times 10^{6} \mathrm{Btu} / \mathrm{BD} \text { tons of reaidue } \\
17 \times 10^{6} \mathrm{Btu} / \mathrm{BD} \text { ton of reaidue } \\
9.9 \times 10^{6} \mathrm{Btu} / \mathrm{ton} \text { of residue }\end{array}$ \\
\hline $\begin{array}{l}\text { Steam Generation } \\
\text { ( } 688 \text { efficiency) }\end{array}$ & & $\begin{array}{l}3.9 \times 10^{12} \text { Btu eteen } \\
\left(116=10^{6} \mathrm{kWh} \text { electrieity)c }\right.\end{array}$ \\
\hline
\end{tabular}

One pound of steam at 80 peig and $312^{\circ}$ p eaturation temperature io equiveleat to 891.7 Btu; therefore $18 \times 10^{6}$ Btu of atean is equivalent to $20,186 \mathrm{lb}$ of team.

$b_{330}$ days operation/year ( $900 \mathrm{z}$ of the year); $24 \mathrm{hr} / \mathrm{day}$.

$c_{116} \times 10^{6} \mathrm{kth}$ electricity is generated by the pover boilers and turbines utilising 30.82 of atees produced. Conversion efficiency of etean to electricity is 33x.

$30 \%$ of the raw material used in the pulp and paper industry in the U.S. originates from wood wastes. 8

Especially. in large plants, disposal of wood residues may become a problem; therefore the. use of residues for generating energy is environmentally and economically sound. The most common method for converting wood residues to energy forms is their direct combustion for generating heat, steam, and electricity.

One acre of U.S. forest produces, on the average, close to 6 BD tons of bark and wood residues per year (equivalent to $102 \times 10^{6}$ Btu of heating value). 13 Use of these residues for energy generation releases residuals that pollute the air, and water streams. An additional and serious environmental consequence of residue utilization is destruction of the physiochemical balance of the soil.

It is estimated 11,12 that fertilizer inputs in pounds for the production of one BD ton of bark and wood residues ( $1 b$ per acre annually $x 15$ year rota$t$ ion divided by 6 BD ton of residues) are as follows:

$$
\begin{array}{lr}
\text { Nitrogen (15 1b/acre-year) } & 37.51 \mathrm{~b} \\
\text { Phosphorus (3 1b/acre-year) } & 7.51 \mathrm{~b} \\
\text { Pocassiuu (11 1b/acre-year) } & 27.51 \mathrm{~b} \\
\text { Calcium (10 1b /acre-year) } & 25.01 \mathrm{~b}
\end{array}
$$


The element content of one BD ton of bark and wood residues in (percent and pounds) is:

$\begin{array}{lrl}\text { Carbon (53.3\%) } & 1070 \text { lb } \\ \text { Hydrogen }(5.8 \%) & 116 \text { lb } \\ \text { Oxygen }(39.2 \%) & 784 \text { lb } \\ \text { Nitrogen }(0.2 \%) & 4 & 1 \mathrm{~b} \\ \text { Phosphorus }(0.01 \%) & 0.2 \mathrm{lb} \\ \text { Potassium }(0.12 \%) & 2.4 \mathrm{lb} \\ \text { Sulfur }(0.01 \%) & 0.2 \mathrm{lb} \\ \text { Misc. Elements (1.36\%) } & 23.2 \mathrm{lb}\end{array}$

Removal of residues from the logging area (and from the forest gen-erally) results in depleting the soil of organic matter and inorganic nutrients. Assuming that $6 \mathrm{BD}$ tons of residues are romovod from one acte of forest land, a considerable amount of nutrients is removed too: $24 \mathrm{lb}$ of nitrogen, $6,420 \mathrm{lb}$ of carbon, $1.2 \mathrm{lb}$ of phosphorus. $14.4 \mathrm{lh}$ nf potassium, and $1.21 \mathrm{~b}$ of sulfur. Erosion, destruction of the balance nf soil microcogmos, uninalching carbon/nitrogen ratio, and decrease of the soil fertility, porosity, and moisture are several concomitant environmental impacts of withdrawal of forest residues from the site of their production.

\subsubsection{Land Requirements}

Land requirements for the model system are estimated to be (a) 4 acres for storage and combustion of residues and (b) 54 forest acres of 30-yr-old trees per year of operation. After harvesting and processing in the pulp/ paper mill, these trees generate $36 \times 10^{3} \mathrm{BD}$ tons of bark. residue and $8 \times 10^{3}$ $B D$ tons of wood residue for the $200 \times 10^{3} \mathrm{BD}$ tons of pulp produced in one year by the model system (that is, 18 such acres per $10^{12}$ Btu unit input). Therefore, over 15 years, $15 \times 54=810$ forest acres would be required. Note that this much land is required for the pump/paper mill feedstock independent of waste processing; the waste-conversion system per se requires only 4 acres.

\subsubsection{Water Requirements}

No water is required during combustion of residues. During processing of pulp and paper and generation of bark and wood residues and black liquor, the paper mill requires an estimated amount of water close to $5 \times 10^{9}$ gallons (25 $\times 10^{3}$ galloins/BD ton of paper produced).

\subsubsection{Operating. Residuals}

There are two major environmental problems with this conversion approach: air emissions and solid residuals. Major air pollutants are particulates $\left(3,145\right.$ tons $\left./ 10^{12} \mathrm{Btu}\right), \mathrm{SO}_{\mathrm{x}}(105$ tons/1012 $\mathrm{Btu}), \mathrm{NO}_{\mathrm{X}}\left(0.699 \mathrm{ton} / 10^{12}\right.$ $B(u), \operatorname{CO}(2,097$ tons/1012 Btu), and hydrocarbons ( 2.446 tons/1012. Btu).

Boiler ash and slag are produced at a rate of 2,097 tons/1012 Btu. Total solids suspended in the water released have been calculated to be close 
to 25 tons/1012 Btu, and the biological oxygen demand (BOD) 5 is estimated to be about 4 tons $/ 10^{12}$ Btu.

The residuals data have been tabulated for the SEAS model and are found in Table 2.2. These calculations of operating residuals are based on the following assumptions. 6

- Annual amount of particulates emitted by the furnaces consuming bark and wood residues and black liquor:

273 tons per mill. Output equivalent per Quad, $3.145 \mathrm{x}$ $10^{6}$ tons.

- Annual amount of sulfur oxides $\left(\mathrm{SO}_{2}\right)$ released from the furnaces burning bark and wood residues and black liquor: 0.54 tons per mill. Output per Quad, $0.105 \times 10^{6}$ tons.

- Annual amount of carbon monoxide released from the combusttion of bark and wood residues and black liquor: 266 tons per mill. Output per Quad, $2.097 \times 10^{6}$ tons.

- Annual amount of hydrocarbons released from the combustion of bark and wood residues and black liquor: 136 tons per mill: Output per Quad, $2.446 \times 10^{6}$ tons.

- Annual amount of solid wastes (ash and slag) generated by the furnaces: 1,480 tons per mill. Output per Quad, 2.097 $\times 10^{6}$ tons.

- Water pollutants from combustion of bark and wood residues and black liquor in pulp and paper mills are assumed negligible. Water use per BD ton of pulp produced, 16.7 tons, and per BD ton of paper produced, 104.3 tons. Waste water released after pulp/paper processing and residue generation contains $10.8 \mathrm{lb}$ total suspended solids plus $1.5 \mathrm{lb}$ of $\mathrm{BOD}_{5}$ per ton of waste water.

Table 2.2. Residuals Data for Combustion/ Cogeneration from Bark and Wood Residues

\begin{tabular}{|c|c|}
\hline Residual & $\begin{array}{c}\text { Gross Residuals } \\
\text { per } 10^{12} \text { Btu } \\
\text { End-Use Energy } \\
\text { (Tons) }\end{array}$ \\
\hline $\begin{array}{l}\text { Particulates } \\
\mathrm{SO}_{2} \\
\mathrm{NO}_{\mathrm{x}} \\
\mathrm{CO} \\
\text { Hydrocarbons, Toxic Hydrocarbons } \\
\text { Ash and Slag } \\
\text { Total Suspended Solids } \\
\mathrm{BOD}_{5}\end{array}$ & $\begin{array}{r}3,145 \\
105 \\
699 \\
2,097 \\
2,446 \\
2,097 \\
25 \\
4\end{array}$ \\
\hline
\end{tabular}


Table 2.3. Construction Costs of Model System for Combustion/Cogeneration from Black Liquor and Bark and Wood Residues

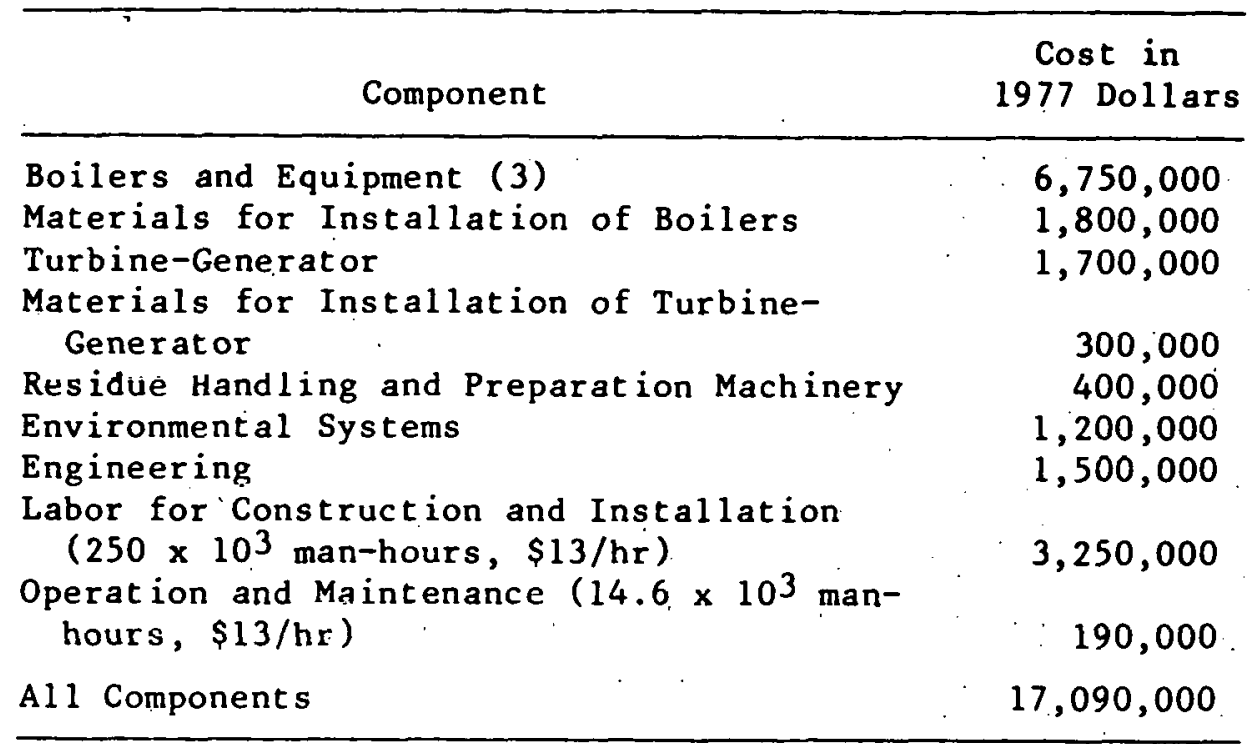

Table 2.4: Capital Expenditures, Materials Requirements, and Energy Summary for Combustion/Cogeneration from Black Liquor and Bark and Wood Residues per $10^{12} \mathrm{Btu}$

\begin{tabular}{|c|c|c|c|}
\hline & 1977 Dollars & Deflator & 1972 Dollars \\
\hline Total Capital Cost & $20,210,000$ & 1.43 & $14,200,000$ \\
\hline $\begin{array}{l}\text { Materials } \\
\text { Construction Labor } \\
\text { Profit and Overhead } \\
\text { Engineering, etc. }\end{array}$ & $\begin{array}{r}12,150,000 \\
3,250,000 \\
3,120,000 \\
1,690,000\end{array}$ & $\begin{array}{l}1.43 \\
1.43 \\
1.43 \\
1.43\end{array}$ & $\begin{array}{l}8,500,000 \\
2,300,000 \\
2,200,000 \\
1,200,000\end{array}$ \\
\hline \multicolumn{2}{|c|}{$\begin{array}{l}\text { Annual System } 10^{12} \text { Btu Output } \\
\text { Total Capital Cost/1012 Annual Btu } \\
\text { Number of Years to Construct Facility } \\
\text { Expected Life uf Facility (yr) } \\
\text { Man Years to Construct Facility } \\
\text { Man Years/1012 Btu Annual Output } \\
\text { Estimated Land Use (acres) }\end{array}$} & \multicolumn{2}{|r|}{$\begin{array}{l}3.9 \\
5,180,000 \\
3 \\
15+ \\
125 \\
32 \\
4^{a}\end{array}$} \\
\hline
\end{tabular}


- Air emissions from combustion of one ton of wood waste are estimated to be $30 \mathrm{lb}$ of particulates, $1.5 \mathrm{lb}$ of $\mathrm{SO}_{\mathrm{x}}, 10$ lb of $\mathrm{NO}_{x}, 2$ to $60 \mathrm{lb}$ of $\mathrm{CO}$, and 2 to $70 \mathrm{lb}$ of hydro-carbons.

\subsection{ECONOMIC DATA}

\subsubsection{Capital Costs}

Production, harvesting, transportation, and delivery to the furnaces of one BD ton of bark and wood residues are estimated to cost $\$ 23.30$ ( $\$ 1.34$ / $\left.10^{6} \mathrm{Btu}\right)$. To arrive at this figure, the following estimates of materials, energy, labor, and capital inputs were assumed (on the basis of references 8,11-14):

- Two "green" tons of bark and wood residues (50\% average moisture content) are equivalent to one $B D$ ton. It is also assumed that one dry pound of residues is equivalent to 8,500 Btu of heating value; therefore one $B D$ ton of residues generates $17 \times 10^{6} \mathrm{Btu}$.

- One acre of U.S. forest produces close to 6 BD tons of bark and wood residues.

- Forest management cost in dollars per BD ton of bark and wood residues is $\$ 15.00$ ( $\$ 6.00$ per acre annually times 15-year rotation of 6 BD tons)

- Fertilizer inputs in pounds and dollars for the production of one BD ton of bark and wood residues (pounds and dollars per acre annually $\times$ 15-year rotation divided by 6 $B D$ tons of residues):

- Nitrogen ( $151 \mathrm{~b} /$ acre-year) $37.51 \mathrm{~b}$ costing $\$ 1.88$ ( $\$ 105 /$ ton)

- Phosphorus ( $31 \mathrm{~b} / \mathrm{acre}$-year) $7.5 \mathrm{lb}$ costing $\$ 0.43$ ( $\$ 95 /$ ton)

- Potassium (11 1b/acre-year) 27.5 lb costing $\$ 1.00(\$ 70 /$ ton $)$

- Calcium (10 lb/acre-year) $25 \mathrm{lb}$ costing $\$ 0.60$ ( $\$ 20 /$ ton $)$

- Pest control' cost in dollars per BD ton of bark and wood residues, $\$ 0.20$.

- Harvesting cost in dollars per BD ton of bark and wood residues, $\$ 1.20$.

- Transporcation cost (from the harvesting site to the mil1) in dollars per $B D$ ton of bark and wood residues, $\$ 3.00$.

In order to estimate the inputs and outputs of the model pulp and paper inill, the assumptions 1 isted above were taken into consideration together with 
records from Arthur D. Little,1 Sittig,2,7 Hall et al.,4 Cheremisinoff and Morresi;8 Reding and Shepherd, 10 Inman et al.,12 Granthan et al., 15 Blake and Salo, 16 Gordian Associates, 17 and U.S. EPA 6 yielding the following data:

- Number of integrated wood pulp and paper mills (Kraft pulping process), 175; annual wood pulp and paper production in BD tons per mill, 200,000.

- Annual wood input in BD tons per mill, 400,000; heating value of one $B D$ ton of wood, $17 \times 10^{6} \mathrm{Btu}$; annual wood (bark not included) residue generation in $B D$ ton per mill ( $2 \%$ of 400,000 BD tons), 8,000 .

- Annual generatiull of bark in BD tons per mill ( $12 \%$ of 400,000 BD tons), 36,000 , heat iuy value of nne BD ton $n$ bark tuyidue, $18 \times 10^{6} \mathrm{Btu}$.

- Annual sawdust input in BD ton per mil1, 120,000; heating value of one BD ton of sawdust, $17.5 \times 10^{6} \mathrm{Btu}$.

- Annual generation of black 1 iquor in tons ( $55 \%$ solids content) per mill, 550,000; combustible content ( 1 ignin, carbohydrates, etc.) of black liquor in tons $(45 \%$ moisture) per mill, 500,000; heating value of the combustible content of a ton ( $45 \%$ water content) of black 1 iquor (1 BD ton releases $\left.13.2 \times 10^{6} \mathrm{Btu}\right), 9.9 \times 10^{6} \mathrm{Btu}(3 / 4$ of $13.2 \times 10^{6} \mathrm{Btu}$ ).

- Annual combustion of wood (including sawdust) residues in $B D$ tons per mill to generate heat, steam, and electricity, 8,000 ; annual combustion of generated bark in BD tons per mill, 36,000; annual combustion of black 1 iquor in tons ( $45 \%$ water content) per mill, 500,000.

- Furnace/boiler efficiency in steam production per mill, 68\%

- Efficiency of conversion of steam to electricity, $33 \%$.

- Annual steam production by the furnaces/boilers combusting bark and wood residues and black 1 iquor in heat equivalent per mill, $3.9 \times 10^{12}$ Btu; $[(8,000$ BD tons of wood $\times 17 \times$ $\left.10^{6} \mathrm{Btu}\right)+\left(36,000 \mathrm{BD}\right.$ tons bark $\left.\times 18 \times 10^{12} \mathrm{Btu}\right)+$ $\left(500,000 \mathrm{BD}\right.$ tons black liquor $\left.\times 9.9 \times 10^{6} \mathrm{Btu}\right) \times 0.68$ efficiency $=3.9 \times 10^{12} \mathrm{Btu}$. Steam is produced by burning black 1 iquor $(86 \%)$ and bark and wood residues $(14 \%)$.

- Annual electricity generation by the power boilers/turbines using steam produced by the combustion of wastes in heat equivalent per mill, $396 \times 10^{9} \mathrm{Btu}\left(116 \times 10^{6} \mathrm{kWh}\right.$; 1 $\mathrm{kWh}=3,413 \mathrm{Btu})$.

- Annual consumption of steam (produced by burning mill residues and fossil fuels) for heat ing and process purposes in heat equivalents per mill ( $3.5 \times 10^{12}$ Btu from mill wastes $+0.1 \times 10^{12}$ Btu from fossil fuels), $3.6 \times$ $10^{12}$ Btu. 
- Annual consumption of electricity in heat equivalents per mill, $566 \times 10^{9} \mathrm{Btu}\left(166 \times 10^{6} \mathrm{kWh}\right)$. Power is generated by gas-oil and steam turbines ( $30 \%$ and $70 \%$, respectively).

The capital cost estimates for our model plant are based on data from a survey performed by the North Central Forest Experiment Station, St. Paul, Minnesota.18 The cost includes expenditures for new boilers, structures, auxiliary plant and turbine plant systems, residue handling and preparation systems, and environmental systems.

The plant uses one power boiler burning bark and wood residues and two main recovery boilers burning the organic matter of black liquor. The energy 1 iberated is used to generate process steam and electricity. In addition a turbogenerator unit is employed.

The basic parts of a boiler are the boiler, grate, dust collector tor', stack, and supporting frame. In addition, there are auxiliary structures and equipment, as well as equipment for handling sludge and ash. It is estimated that a boiler of 150,000 pounds of steam per hour (pph) capacity (consuming bark and wood) costs $\$ 2,250,000$ ( $\$ 15 / \mathrm{pph} \times 150,000 \mathrm{pph}=$ $\$ 2,250,0000)$. The installation cost for the boiler is estimated to be close to one-fourth of the cost of the boiler, that is, $\$ 600,000$. This boiler is designed to generate process steam at $600 \mathrm{psig.} \mathrm{Therefore} \mathrm{the} \mathrm{cost} \mathrm{of} \mathrm{three}$ such boilers installed is $\$ 8,550,000$ (1977 dollar value).

The turbogenerator costs $\$ 1,700,000$ plus $\$ 300,000$ for installation. In addition to boilers and tubogenerator, the environmental control systems operating in the model system cost $\$ 1,200,000$ (1977 dollar value).

Material and cost estimations are presented in Table 2.3 and capital cost requirements are given in 1977 dollar values. Table 2.4 summarizes capital expenditures and materials requirements for the model system per $10^{12}$ Btu.

\subsubsection{Operating and Maintenance Costs}

It has been estimated that $14.6 \times 10^{3}$ man-hours are needed for operation and maintenance of the furnaces/boilers of the model system. Capital cost of operation and maintenance is estimated at $\$ 190,000\left(14.6 \times 10^{3}\right.$ manhours at $\$ 13 / \mathrm{hr})$.

\subsection{SUMMARY OF FINDINGS}

Table 2.5 summarizes the estimates relevant to the pulp and paper mill residues combusted for generation of steam, heat, and electricity. The numerical data are estimated nationwide averages, and the calculated costs are expressed in 1977 dollars. Estimated energy is given in Btu heat equivalents, and the weights are given in short tons.

Tabulated costs and energy-balance estimations reveal the magnitude of gains and losses depending on whether the residuals liberated during the manufacturing process are recycled. 
Table 2.5. Energy Generation from Black Liquor and Bark and Wood Residues

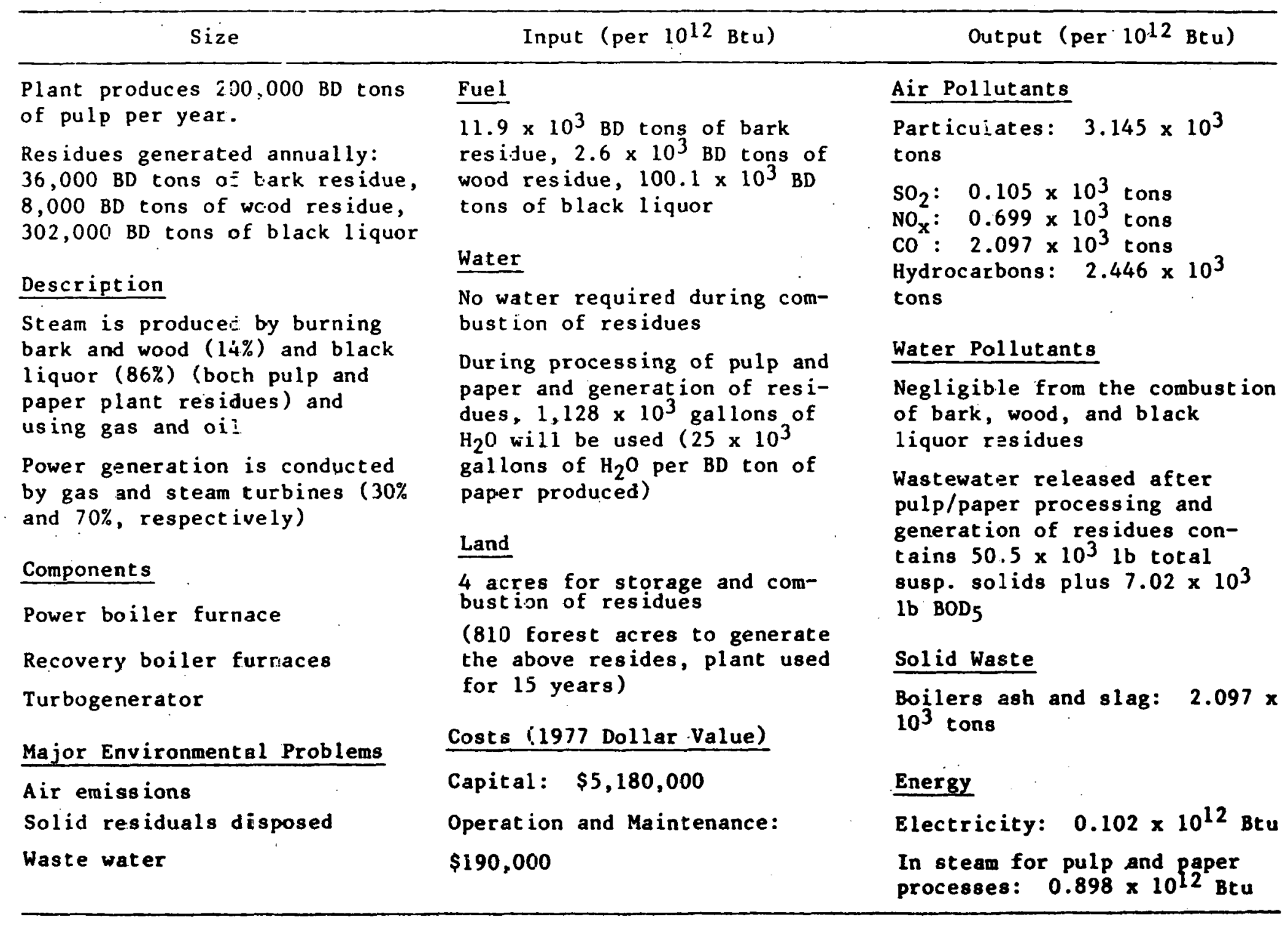




\section{REFERENCES}

1. Little, Arthur D., Inc., Environmental Considerations of Selected Energy Conserving Manufacturing Process Options, Vol. 5, Pulp and Paper Industry Report, Report EPA-600/7-76-034e, U.S. Environmental Protection Agency, Cincinnati, Ohio (1977).

2. Sittig, M., Pulp and Paper Manufacture: Energy Conservation and Pollution Prevention, Noyes Data Corp., Park Ridge, N.J., pp. 429 (1977).

3. Federal Energy Administration, Project Independence Blueprint -- Final Task Force Report -- Energy Conservation in the Manufacturing Sector: 1954-1990, Report PB-248, p. 495 (1974).

4. Hal1, E.H., W.T. Hanna, L.D. Reed, J. Varga, D.N. Williams, K.E. Wilkes, B.E. Johnson, W.J. Mueller, E.J. Bradbury, and W.J. Frederick, Final Report on Evaluation of the Theoretical Potential for Energy Conservation in Seven Basic Industries, Battelle Columbus Laboratories, Columbus, Ohio, Report PB-244, Federal Energy Administration, Washington D.C. p. 772 (1975).

5. Biomass Energy Institute, Inc., Biomass Energy Success Stories: A Portfolio Illustrating Current Economic Uses of Renewable Biomass Energy, U.S. Department of Energy, Assistant Secretary. for Energy Technology, Division of Solar Technology, HCP/T0285-01, UC-61 (March 1978).

6. U.S. Environmental Protection Agency, Development Document for Interim Final and Proposed Effluent Limitations Guidelines and Proposed New Source Performance Standards for the Bleached Kraft, Groundwood, Sulfite, Soda, Deink and Non-Integrated Paper Mills Segment of the Pulp, Paper and PaperBoard Point Source Category, Vols. 1 and 2, Report EPA 440/1-76-947a, . p.735 (1976).

7. Sittig, M., Environmental Sources and Emissions Handbook, Noyes Data Corp., Park Ridge, N.J., Pp. 519-521 (1975).

8. Cheremisinoff, P.N., and A.C. Morresi, Energy from Wood Wabter, Environment 19(4):25-31 (April 1977).

9. Ford, Bacon, and Davis, Inc., Draft Target Support Document for Energy Efficiency, Improvement Target in the Paper and Allied Products Industry (SIC 26), Federal Energy Administration, (1976).

10. Reding, J.T., and B.V. Shepherd, Energy Consumption: Paper, Stone/Clay/ Glass/Concrete and Food Industries, Report PB-241, Environmental Protection Agency, Research Triangle Park, N.C., p. 926 (1975).

11. U.S. Department of Agriculture, The Outlook for Timber in the United State6, U.S. Dept. of Agriculture, Forest Service; Forest Resource Report No. 20 (1973). 
12. Inman, R.E., et al., Silvicultural Biomase Farms, Vol.1-5, iechnical Report 7347, Mitre Corp.; ERDA, Washington, D.C. (1977).

13. Ribe, J.H., A Review of Short Rotation Forestry, Misc. Report 160, Life Sciences and Agricultural Experiment Station, University of Maine Orono, Maine (1974).

14. Howlett, K., and A. Gamache, Forest and Mill Residues and Potential Sources of Biomas6, Vol. 6, Silvicultural Biomass Farms, Technical Report 7347, Mitre Corp.; ERDA, Washington, D.C. (1977).

15. Granthan, J.B., et al., Energy and Raw Material Potentials of Wood Residue in the Pacific Coast States, U.S. Dept. of Agriculture Forest Service, Pacific Northwest Forest and Range Experiment Station, Portland, Orè. (1973).

16. Blake, D., and D. Salo, Systems Descriptions and Engineering Costs for Solar-Related Technologies, Biomass Fuels Production and Conversion Systems, Vol. 9, Mitre Corp., New York (1977).

17. Gordian Associates, Inc., Selected Paper Product8, The Data Base: The Potential for Energy Conservation in Nine Selected Industries, Vol. 8, Federal Energy Administration, Washington, D.C. (1974).

18. U.S. Department of Agriculture, Forest Residues Energy Program, USDA/F.S. North Central Forest Exp. Sta., St. Paul, Minnesota, p.297 (1978). 
3 HYDROLYSIS OF CORN RESIDUES TO OBTAIN FURFURAL

ABSTRACT

In this section the extraction of furfural from corn residues by acid digestion and subsequent distillation is analyzed in terms of capital and environmental costs. The analysis is based on use of a model furfural plant capable of producing over 44,000 tons of furfural per year; such a plant would be approximately four times larger than required for economically viable production. Production of furfural from corn residues is economically sound and would make it possible to substitute furfural for certain refined petroleum products, and the energy generated by the model system could be doubled by marketing its by-products (acetic acid, methanol, and methyl acetate). However, removal of all corn residues rapidly depletes the soil, and expensive nutrient programs would be required to maintain soil productivity.

\subsection{INTRODUCTION}

\subsubsection{General Systems Description}

Furfural is an aldehyde with the - CHO group in the position and is obtained from pentosan-containing agricultural residues. It was identified in 1832, and its production was commercialized by Quaker Oats in 1922.1 Table 3.1 ists the pentosan content and furfural yield that can be expected from various agricultural residues.

Furfural is the most industrially important furan, a class of heterocyclic compounds characterized by a double saturated ring of four carbons and one oxygen atom. 5 It serves as a chemical intermediate for the production of furfuryl alcohol, tetrahydrofurfuryl alcohol, furan, tetrahydrofuran, and polytetramethylene ether glycol, and as a precursor of pyrrole, pyrrolidine, pyridine, piperidine, lycine methylfuran, and many other compounds with important applications. 1 Furfural is also used as a selective solvent in the refining of lubricating oils to increase their stability during processing, 6 as an extractive distillation medium in the manufacture of butadiene from petroleum, 7 as a decolorizing agent for wood resin, and as a resin former. 8 Furfural may also have other industrial uses that are currently being served by petroleum-derived chemicals.

The focus of this section is the production of furfural from corn residues (corncobs and cornstalks). Furfural is included in this study of biomass energy resources because it is an organic compound that spares petroleum-derived industrial chemicals: if furfural were not derived from biomass, it or its analog would most likely come from petroleum.

\subsubsection{Resource Distribution}

If corn residues are used to produce furfural, the regional applications should be located in the Corn Belt. The distribution of acreage planted to corn in the U.S. is presented in Fig. 3.1. A three-state area 


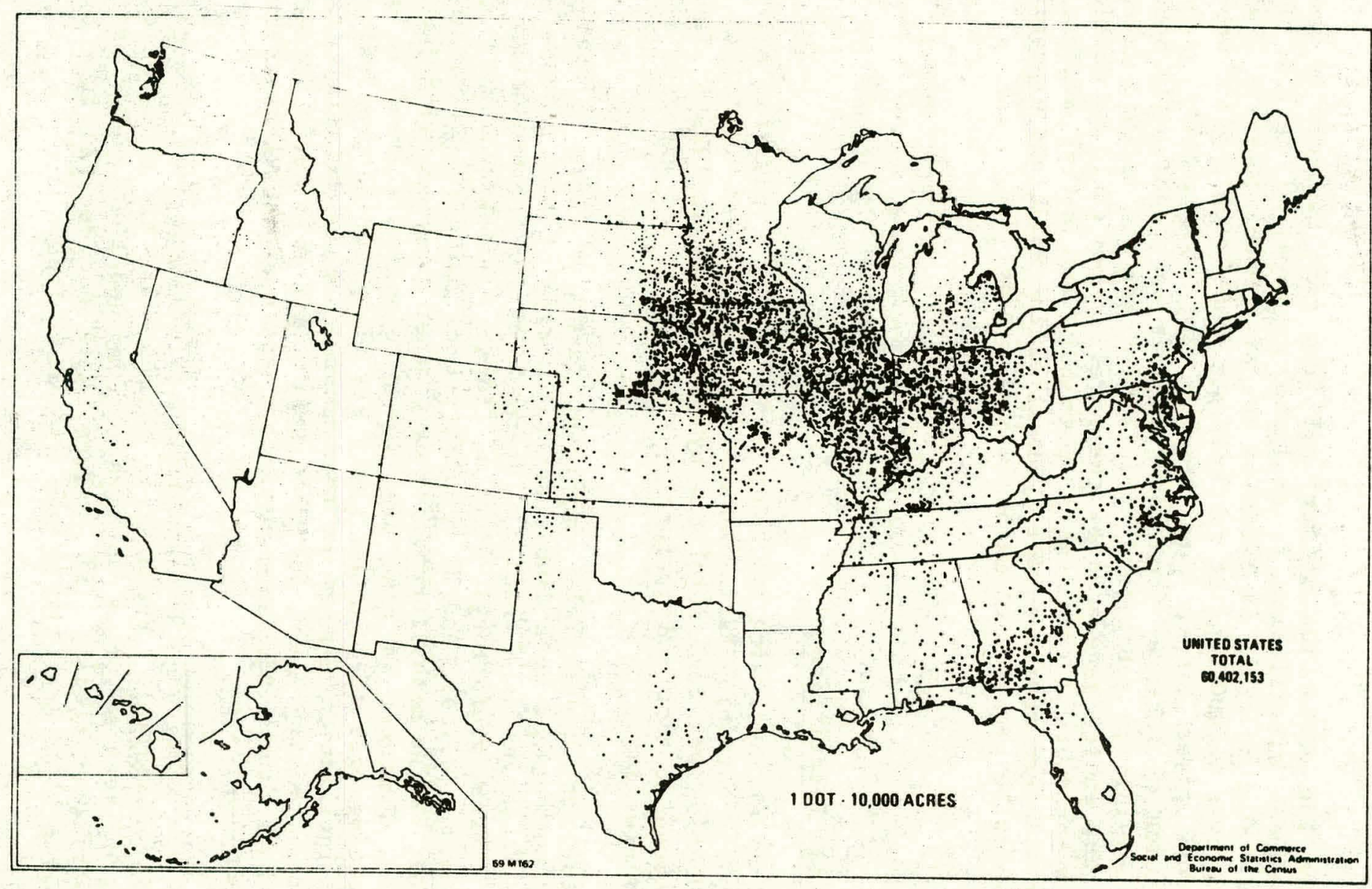

Fig. 3.1. Corn Harvested, 1969 
Table 3.1. Pentosan Content and Furfural Yield for Selected Agricultural Residues

\begin{tabular}{lcc}
$\begin{array}{c}\text { Agricultural } \\
\text { Residue }\end{array}$ & $\begin{array}{c}\text { Pentosan Contenta } \\
\text { (\% dry basis) }\end{array}$ & $\begin{array}{c}\text { Furfural Recoveryb } \\
\text { (\% dry basis) }\end{array}$ \\
\hline Corncubsc & 19 & 12.9 \\
Bagasse & 15 & 9.6 \\
Oat Hulls & 20 & 12.3 \\
Rice Hulls & 12 & 6.3 \\
Cornstalks & $17: \because \ldots$ & $6.5-9.5$ \\
Cottonseed Hulls & 18 & 10.2 \\
\hline
\end{tabular}

aitchcock and Duffey. 2

bPatural1.3

clipinsky et 81.4

in the Midwest ( 11 inois, Iowa, and Indiana) accounts for approximately $50 \%$ of the corn produced in the U.S. Average corn yields ranged from 2.7 to 3.08 tons/acre in 1976,10 and average residue yields were estimated at between 2.89 and 3.3 tons/acre. Residue yields were calculated from grain yields using a ratio of $1: 1.07$, grain:residue, on a dry weight basis.11-14 Using this ratio, it is estimated that in 1976 over $90 \mathrm{million}$ tons of corn residues were generated in the above three midwestern states (see Table 3.2).

Since this area contains some of the world's most productive soils, it is ideal for evaluating the effects of total crop removal on the soil and the environment. Corn in this area is grown continuously or in a corn-soybean rotation. The yield per acre and the acreage in corn have steadily increased in recent years.10 This trend will probably continue, but $c 1$ imatic and economic fluctuations must be taken into account. If corn and other crop residues are to be a viable biomass energy alternative in the Corn Belt, consideration must be given to the consequences of crop residue removal on soil quality in order to maintain land productivity.

\subsection{DESCRIPTION OF MODEL SYSTEM}

\subsubsection{System Description}

Extraction of furfural from corn residues involves acid digestion under steam pressure followed by a series of distillations to separate and purify the furfural and other by-products of the hydrolysis. The flow diagram for furfural production (Fig. 3.2) illustrates the unit operations and processes required for furfural production. This flow diagram was construcced from descriptions of the process provided by several authors $1,3,4,15-17$ and serves as the basis for assessing the material and energy flows required for furfural production in our model system.

The process begins with milling of corn residue $(25 \%$ cob, $75 \%$ stalk materials) into fine particles while the hydrolysis water is mixed ( 1 part 


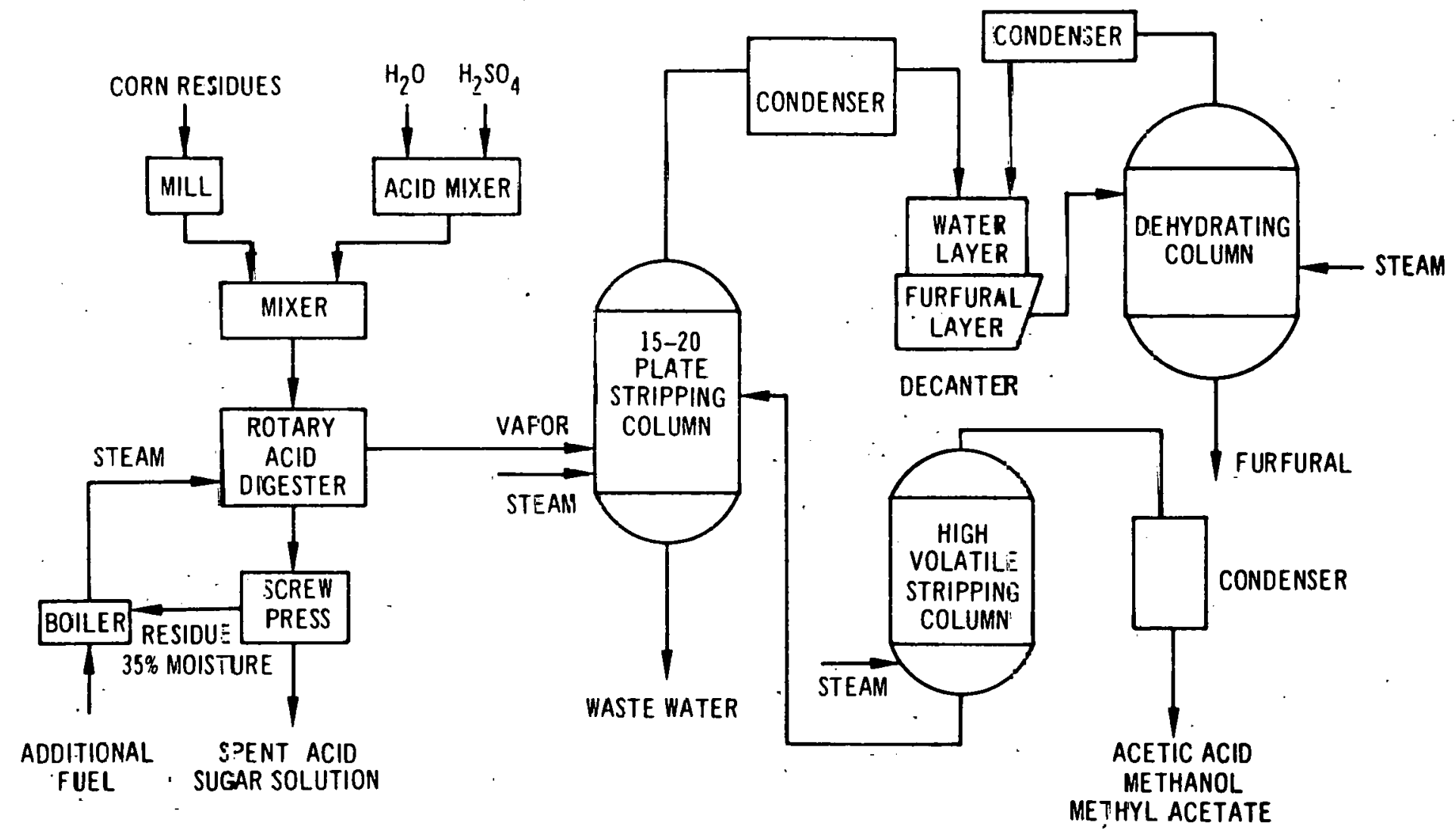

Fig. 3.2. Process Flow Diagram for Production of Furfural from Corn Residues 
Table 3.2. Corn - Grain, and Residue Production, and Energy Value of Residues: Three Midwestern States and U.S., 1976

\begin{tabular}{|c|c|c|c|c|c|c|}
\hline Locetion & $\begin{array}{c}\text { Grain" } \\
\text { (bushelo/acre) }\end{array}$ & $\begin{array}{c}\text { Grain } \\
\text { (cons/acre) }\end{array}$ & $\begin{array}{l}\text { Residueb } \\
\text { (tons/acre) }\end{array}$ & $\begin{array}{c}\text { Tocal } \\
\text { Harveated } \\
\text { Acreage } \\
\left(10^{3} \text { acres }\right)\end{array}$ & $\begin{array}{c}\text { Totel } \\
\text { Renidue } \\
\left(10^{6} \text { cons) }\right.\end{array}$ & $\begin{array}{c}\text { Total } \\
\text { Energy } \\
\text { Yaluec } \\
\left(10^{12} \text { Btu }\right)\end{array}$ \\
\hline $\begin{array}{l}\text { Illinois } \\
\text { Indiana } \\
\text { Iowe } \\
\text { Three-State Total } \\
\text { U.S. Total }\end{array}$ & $\begin{array}{c}107.0 \\
110.0 \\
90.0 \\
- \\
87.4\end{array}$ & $\begin{array}{c}3.00 \\
3.08 \\
2.70 \\
- \\
2.45\end{array}$ & $\begin{array}{c}3.21 \\
3.30 \\
2.89 \\
- \\
2.62\end{array}$ & $\begin{array}{r}11,690 \\
6,300 \\
12,750 \\
30,740 \\
71,085\end{array}$ & $\begin{array}{r}37.5 \\
20.8 \\
36.8 \\
95.1 \\
186.2\end{array}$ & $\begin{array}{r}413.5 \\
229.3 \\
405.8 \\
1,048.6 \\
2,053.0\end{array}$ \\
\hline
\end{tabular}

concentrated $\mathrm{H}_{2} \mathrm{SO}_{4}$ plus 9 parts $\mathrm{H}_{2} \mathrm{O}$ ). The two streams are then mixed to yield a liquid/solid ratio of approximately 0.25 .17 Hydrolys is takes place in a rotary digester, and steam ( 50 to $100 \mathrm{psi}$ ) ) is passed through the mixture for 6 to 12 hours depending on the pressure of the stream.3,16 The material remaining after complete digestion is separated into solid and liquid fractions by a screw press.

The solid residue is granular and composed principally of modified cellulose, lignin and resins, and ash, with $2-3 \%$ acid measured as sulfuric. 18 A more detailed chemical description of the solid residue is given in Table 3.3. On leaving the press the residue has a moisture content of $35 \%$ and a heating value of $4,174 \mathrm{Btu} / 1 \mathrm{~b}^{4}$ and accounts for $70 \%$ of the initial weight of the raw material.3 The liquid fraction contains the dissolved carbohydrates and spent acid. Given that $70 \%$ of the initial weight of the raw materials is in the solid residue and that the furfural extracted accounts for approximately $8-10 \%$ of the input material, one can estimate that $20-22 \%$ of the raw material is dissolved in the water from the screw press. Both these by-products may have value: the solid residue can be burned in the boilers to produce steam or it can be sold as animal feed, 18 and Lipinsky et al. 4 have postulated that the liquid fraction could be fermented into ethanol. In this model it is assumed that the solid residue will be burned to produce steam and that the liquid fraction is a waste stream.

The steam that has passed through the acid digester contains $4-6 \%$ furfural.16 The furfural is recovered from the vapor by passing it through a distillation column. The vapors leaving the column are $20-25 \%$ furfural, and water leaving the bottom of the distilling column usually contains $0.02-0.05 \%$ furfural by weight.1 The overhead is then condensed, and a furfural layer and a water layer are separated by decanting. Furfural leaving the decanter contains $5.8 \%$ water, 1 and the water leaving the decanter contains about $10 \%$ furfural.16 The furfural layer is then passed through a dehydration column which employs vacuum distillation and requires 0.25 lb steam per pound of furfural vaporized. 1 The resultant furfural has a purity of $99.5 \% .16$ The overhead from the dehydration column is then recovered by condensation and recycled through the decanter. 
Table 3.3. Chemical Composition of Solid Residue By-Product from Furfural Production

\begin{tabular}{lc}
\hline \multicolumn{1}{c}{ Chemical Fraction } & $\%$ (dry basis) \\
\hline $2 \%$ Caustic Soda Extract & 22 \\
Alcohol-Soluble & 21 \\
Acetone Extract & 20 \\
Ether-Extractable & 4 \\
Cellulose & 38 \\
Residue from Saccharification $\quad$ \\
$\quad$ (1ignin and resins) & 42 \\
pH & $3-15$ \\
Protein (N x 6.25) & $2.9-4.2$ \\
Crude Fat & $2.5-4.2$ \\
Crude Fiber & $45-58$ \\
Ash & $2.8-15$ \\
Nitrogen-Free Extract & $38-46$ \\
Carbon & $50-53$ \\
Hydrogen & $5.1-5.3$ \\
Nitrogen & $0.7-0.9$ \\
Oxygen & $36-38$ \\
Sulfur & $1.2-1.7$ \\
\hline
\end{tabular}

Source: ref. 18.

The water layer in the decanter yields highly volatile by-products, namely, methyl alcohol, methyl acetate, and acetic acid. The production of methyl alcohol and methyl acetate equals roughly one-sixteenth of furfural production at the plant, while that of acetic acid equals the production of furfural.4 These compounds are recovered by passing the water layer through a stripping column and recovering the compound by condensing the overhead. The material remaining in the column is then recycled through the system, beginning with the original distillation of the furfural vapor coming from the digesters.

\subsubsection{Material Requirements}

The material flows proposed for the model furfural production system are given in Table 3.4. The model syscem prupused has approximately fonr times the minimum economically viable capacity for furfural production in the U.S.17 The capacity of this plant is over 44,000 tons of furfural per year, which is roughly equivalent to $50 \%$ of U.S. production.

\subsection{ENVIRONMENTAL DATA}

\subsubsection{General Soil Effects}

Total removal of residues from corn, wheat, and cotton fields has the same ultimate effect on the soil although the rate will vary because of dif- 
Table 3.4. Material and Energy Flows for Model Furfural Production System

\begin{tabular}{lr}
\hline System Variable & \multicolumn{1}{c}{ Material Flow } \\
\hline Plant Capacity & 44,550 tons/yr furfural \\
Processing Rate & $524,040 \mathrm{tons} / \mathrm{yr}$ corn stover \\
& $135 \mathrm{tons} / \mathrm{day}$ furfural \\
& $1,588 \mathrm{tons} / \mathrm{day}$ corn stover \\
Utilities & $40,000 \mathrm{lb} \mathrm{steam} / \mathrm{ton}$ furfural \\
& $11,000 \mathrm{ft}^{3} \mathrm{H}_{2} \mathrm{O} / \mathrm{ton}$ furfural \\
& $250 \mathrm{kWh} / \mathrm{ton}$ furfural \\
Acid Digestion & $50 \mathrm{lb}$ conc. H2SO4/ton Residue \\
By-Product Recovery & 8.4 tons methyl alcohol/day \\
& 8.4 tons methyl acetate/day \\
& 135 tons acetic acid/day \\
\end{tabular}

Data estimated from refs. $3,4,16$.

ferences in crop root systems, plant physiology, climatic conditions, and soil properties. Soil destruction begins with the first harvest of residue because the soil is completely exposed to water and wind. Bradyly reports that Wischmeir and Mannering found that removing residues increased runoff from 0.52 inch to 0.98 inch on 678 plot-years of corn. When residues are removed, the raindrop effect destroys surface soil structure, causing puddling, decreased water infiltration, soil compaction, reduced porosity, and a loss of organic matter. In wheat and cotton growing areas, wind takes over after the soil has dried. Wind sorts the surface material, blowing away the fines and leaving only the semisterile skeletal matter. 20

Organic matter acts as a binding agent to develop and maintain soil structure, by maintaining good tilth, increasing infiltration, maintaining soil porosity, and acting as a counter force against soil compaction.19,21 Organic matter serves as a storehouse for nutrients, increases cation and. anion exchange capacity, and chelates micronutrients, protecting plants from potentially toxic concentrations.19,21-23. Organic matter in high organicmatter soils releases 40-80 lb/acre of nitrogen for crop uses. 22, 23". Removal i) $\mathrm{f}$ al residues from fields where corn was grown continuously during a period. of 18 years resulted in a 15,000-1b/acre decrease in organic matter.2?

Not all residues need to be returned to the snil to maintain organic carbon content. Larson and others 24 found that by using conservation tillage (e.g., chisel plow) $1 \%$ to $57 \%$ of the corn area in selected land resource areas of Minnesota and Iowa could have all the residues removed without losing more than 4 tons of soil per acre per year. However, these are only calculated data; the amount of residues that can be safely removed from an area depends on the soil, climatic ronditions, and especially management practices such as type of tillage and fertility program. 24 
The adverse effect of removing corn residues on the chemical properties of soil can be partially overcome by increased fertilizer application. Data presented in this report are only for the first year that crop residues are removed. The second year, fertilizer rates must be increased to replace that portion of the nutrients removed by the grain, residue, and erosion. Maintaining favorable chemical properties over a period of several crop years could be more costly in terms of energy required for fertilizer than the amount of energy in the residue. Unfortunately, the adverse impact on the physical properties of the soil can only be slowed down with higher fertilizer rates. It takes the continual passing of crop residues through the soil and being transformed into organic matter to stop the deterioration of soil physical properties. 21,23

\subsubsection{Some Aspects of Corn Residue Romoval}

Table 3.5 shows the inputs needed to obtain a yield of 107 bushels/acre of corn. Data taken from Pimentel et al. 25 were adjusted to reflect the increased yield. Assumption that a linear relationship exists between expected yield and fertilizer rates 28 made calculation of the nutrient data possible.

The amount of fertilizer nitrogen applied to the soil for corn production is based on maximum economic return.28 other nutrients (phosphorus and potassium) are added on the basis of soil tests that indicate the amount of nutrient needed for maintenance of optimum crop yield plus a build-up factor that provides for fixation of these nutrients by soils that are low in these elements. Calcium and magnesium are seldom required for Illinois soilo.

Table 3.5. Inputs per Year Needed to Obtain a Corn Yield of 107 Bushels of Grain and 3.21 Tons of Residue per Acre undel Continuous Cropping System in Illinois

\begin{tabular}{lcc}
\hline Input & Amount per Açre & $\begin{array}{c}\text { Amount per } \\
\text { Ton of Residue }\end{array}$ \\
\hline $\begin{array}{l}\text { Nutrients (1b) } \\
\text { Nitrogen }\end{array}$ & 148 & 46.1 \\
Phosphorus & 41 & 12.8 \\
Potassium & 79 & 24.6 \\
Salciull & $64^{\mathbf{d}}$ & $19 / .8$ \\
Magnesium & 1 & 0.33 \\
Seed (1b) & 19 & 5.9 \\
Active Ingredients in & & 0.93 \\
Pésticides (1b) & 3 & 6.9 \\
Gasoline (gal) & 22 & \\
\hline
\end{tabular}

Data sources: refs. 10,25-28.

ayearly rate assuming that soils are limed every 4 th year. 
These soils are rich in basic cations; however, the advent of continuous corn production with high application of nitrogen fertilizer made the addition of agricultural lime necessary to maintain a $\mathrm{pH}$ of 6.5 in the surface soil horizon:

Table 3.6 shows the approximate amounts of nutrients removed in the grain and residue. When only the grain is removed, the fertilizer added to produce this crop (Table 3.5 ) is adequate ts maintain the productivity of the soil; however, the loss of nutrients by erosion (Table 3.7) eliminates most of the build-up fertilizer applied. Also the material eroded away usually contains a high proportion of nutrients that are readily available to plants. In some experiments the material eroded away contained five times more organic matter and nitrogen than the original soil. 9

Data in Tables 3.6 and 3.7 show that nutrient losses greatly increase because erosion increases and that nutrients in crop residues are also lost when these residues are completely removed. Nitrogen losses are 1.6-2 times greater than the amount applied, and phosphorus losses are $1.2-1.6$ times greater than the amount applied. Potassium losses are 10.6-16.7 times greater than the amount applied, and magnesium losses are 130-200 times greater. Cậlcium losses are high because of erosion, but the total calcium loss is not greater than the amount applied. No sulfur is applied unless a deficiency, is noted; however, at the rate of removal indicated in Tables 3.6 and 3.7 it will not take many growing seasons for sulfur deficiencies to appear in curn plants. Trace elements are not normally added to the soil as fertilizer, but sprayed on the growing plants when deficiency symptoms become evident. Some soils already exhibit deficiencies in sulfur and some of the trace elements;28 therefore a management system in which corn is grown in monoculture and the

Table 3.6. Nutrients and Mineral Matter Removed by Corn Cropa

\begin{tabular}{|c|c|c|c|c|}
\hline & \multicolumn{2}{|c|}{ Grain } & \multicolumn{2}{|r|}{ Residue } \\
\hline & $\begin{array}{l}\text { Pounds } \\
\text { per Acre }\end{array}$ & $\begin{array}{l}\text { Pounds per } \\
\text { Ton of Grain }\end{array}$ & $\begin{array}{l}\text { Pounds } \\
\text { per Acre }\end{array}$ & $\begin{array}{c}\text { Pounds per } \\
\text { Ton of Residue }\end{array}$ \\
\hline Nitrogen & 96 & 32.0 & 71.3 & 22.2 \\
\hline Phos phorus & 16.6 & 5.5 & 11.4 & 3.6 \\
\hline Potassium & 23.6 & 7.9 & 85.8 & 26.8 \\
\hline Calcium & 11.4 & 3.8 & 19.6 & 6.1 \\
\hline Magnes ium & 14.0 & 4.7 & 12.1 & 3.8 \\
\hline Sulfur & 10.2 & 3.4 & 7.0 & 2.2 \\
\hline Copper & 0.04 & 0.013 & 0.04 & 0.012 \\
\hline Manganese & 0.06 & 0.020 & 1.07 & 0.334 . \\
\hline Zinc & 0.11 & 0.037 & 0.2 .1 & 0.066 \\
\hline Mineral Matter & - & - & 371.9 & 116.0 \\
\hline
\end{tabular}

Data sources: refs. $21,29,30$.

aThe assumption was made that a linear relationship exists between crop yield and nutrient uptake; therefore the data were adjusted for a yield of 107 bushels/acre. 
Table 3.7. Nutrients Lost by Soil Erosion under Continuous Corn Production with Two Residue-Management Techniques a

\begin{tabular}{|c|c|c|c|c|c|c|}
\hline \multirow{2}{*}{$\begin{array}{l}\text { Nutrient Loss } \\
\text { Measurement }\end{array}$} & \multicolumn{6}{|c|}{ Nutrient } \\
\hline & $\mathbf{N}$ & $\mathbf{P}$ & K & $\mathrm{Ca}$ & $\mathrm{Mg}$ & s \\
\hline \multirow{4}{*}{$\begin{array}{l}\text { Pounds Lost/Yr } \\
\text { Pounds Lost/Ton } \\
\text { of Residues }\end{array}$} & & RES IDUES & REMOVED. & & & \\
\hline & $79-132$ & $22-36$ & $726-1,210$ & $264-440$ & $104-174$ & $20-34$ \\
\hline & $25-41$ & $\cdot 7-11$ & $226-377$ & $82-137$ & $33-54$ & $6-11$ \\
\hline & & RESIDUES & RETURNE D & & & \\
\hline $\begin{array}{l}\text { Pounds Lost / Acre } \\
\text { Pounds Lost/Ton }\end{array}$ & 66 & 18 & 605 & 220 & 87 & 17 \\
\hline of Residues & 21 & 6 & 189 & 69 & 27 & 5 \\
\hline $\begin{array}{l}\text { Pounds Lost/lion } \\
\text { of Grain }\end{array}$ & 22 & 6 & 202 & 73 & 29 & 6 \\
\hline
\end{tabular}

Data sources: refs. 19,24 .

a Data can vary between $120 \%$ and $200 \%$ increase in soil and nutrient 10 ss. For this study we used a range of nutrient loss because the exact increase depends on many factors (e.g., soil type, tillage method, slope).

total crop is removed will only increase the number of acres that must have these nutrients supplied by fertilizers. There are addditional losses of nutrients, particularly nitrogen, by the leaching process. Nutrients move down through the soil out of the root zone and are no longer available to corn planes.

Table 3.8 lists the nutrients that must be returned to the soil to maintain productivity. These data are given both per ton of residue removed and per $10^{12}$ Btu out put.

\subsubsection{Operating Residuals}

The two major environmental problems resulting from furfural production are water and air contamination by organics and sulfuric acid. Solid residue is also generated in the process, bul lhis lias putential as fuel or feed and should not be considered a pollutant.

Lacking a published estimate for hydrocarbon and acid losses into the atmosphere during the process, it was assumed that $1 \%$ of the total hydrocarbons produced (furfural, methanol, methyl acetate, and acetic acid), or $1,011.6$ tons per $10^{12}$ Btu generated, are lost to the atmosphere. The $1 \%$ assumption was also made for sulfuric acid losses, calculated at 140 tons per $10^{12}$ Btu.

The major water pollutant is the carbohydrate dissolved in the liquid after digestion; it was estimated that the carbohydrate in the waste pro- 
cess equals $12 \%$ of the input residue and has a biological oxygen demand of $0.4 \mathrm{lb} / \mathrm{lb}$ carbohydrate (similar to flucose). This results in a BOD of 26,880 tons per $10^{12} \mathrm{Btu}$. The water pollution from sulfuric acid was assumed to be equal to $20 \%$ of the input acid, or 2,800 tons per $10^{12}$ Btu. A summary of these residuals is shown in Table 3.9 .

\subsubsection{Land Requirements}

It is estimated that 300 acres per plant site. ( 320.6 acres per $10^{12}$ Btu) will be required for the plant. Additional land to supply the residue (approximately 0.25 acre/ton residue) will also be needed.

\subsubsection{Water Requirements}

The two main water demands for hydrolysis are for process water $(3,000$ gallons/ton furfural) and cooling water (13,000 gallons/ton furfural). Plant operation requires $814,323,000$ gallons of water per $10^{12}$ Btu.

Table 3.8. Nutrient Replacement Required when Corn Residue is Removed for Furfural Production

\begin{tabular}{lcc}
\hline Nutrient & $\begin{array}{c}\text { Replacement per Ton of } \\
\text { Residue }(20 \% \text { Moisture) } \\
(\text { tons) }\end{array}$ & $\begin{array}{c}\text { Replacement per } \\
10 \text { Btu } \\
\text { (tons) }\end{array}$ \\
\hline Nitrogen & 0.0185 & 10,360 \\
Phosphorus & 0.0051 & 2,856 \\
Potassium & 0.0099 & 5,544 \\
Calcium & 0.079 & 44,240 \\
Magnesium & 0.00013 & 72.8 \\
\hline
\end{tabular}

Table 3.9. Residuals Data for Hydrolysis of Corn Residues

\begin{tabular}{lc} 
Residual & $\begin{array}{c}\text { Gross Residual } \\
\text { per 1012 Btu } \\
\text { End-llse Energy } \\
\text { (Tons) }\end{array}$ \\
\hline $\begin{array}{l}\text { Hydrocarbons, Toxic Hydrocarbons } \\
\text { Other Gases, Sulfur }\end{array}$ & $1,011.6$ \\
Biological Oxygen Demand & 140 \\
Sulfuric Acid & 26,880 \\
\hline
\end{tabular}




\subsection{ECONOMIC DATA}

\subsubsection{Capital Costs}

A bottom-up approach was used for estimating the capital costs and material inputs of the furfural production plant. A list of process equipment was developed from the process flow diagram; estimates of costs for each piece were determined by using published cost data for similar equipment 31 and modifying where we felt necessary.

Once the process equipment costs were determined, other direct and indirect costs were calculated from the process equipment estimate. Table 3.10 gives a breakdown of capital costs for a typical multiprocess chemical plant. These estimates are witlin the rangea incurred during chemical plant construction. 32 Using Table 4.1, other costs were inferred on the basis of the process cost estimate. These results are found in Tables 3.11 and 3.12. The total capital cost for the syslem was eslimated at $\$ 28,685,384$ (1972 dollars).

\section{4 .2 Operating Costs}

Operating costs for the facility were taken from estimates for a furfural plant of equivalent size that used bagasse in place of corn residues. 31 The operating cost breakdown is given in Table 3.13. An additional factor is the cost of the residue, which is estimated at $\$ 20 / t$ on field-dried and delivered (1977 dollars).

Credits can be obtained from selling or using the following by-products: solid residue $\left(\$ 1.00 / 10^{6} \mathrm{Btu}\right)$, acetic acid $(\$ 2,000 / t \mathrm{on})$, methyl alcohol $(\$ 2,000 /$ ton $)$, and methyl acetate $(\$ 14,000 /$ ton $)$.

Table 3.10. Anticipated Distribution of Capital

Costs for a Multiprocess Plant

\begin{tabular}{lc}
\hline Cost Component & $\begin{array}{c}\text { Percent } \\
\text { of }\end{array}$ \\
\hline Site and Preparation Costs \\
Buildings and Auxiliaries & 1.5 \\
Construction Labor & 10.0 \\
Process Material (includes concrete & 6.5 \\
$\quad$ substructures, piping and ductwork, & 13.0 \\
$\quad$ electricil, insilatinn, process & \\
structural, instrumentation, paint) & 8.0 \\
Process Material Labor & 32.5 \\
Process Equipment & 3.0 \\
Process Equipment Lainr & 15.5 \\
ilome Office Expense (including overhead) & 10.0 \\
Field Office Expense (including overhead) & \\
\hline
\end{tabular}


Table 3.11. Capital Costs for Model System for Hydrolysis of Corn Residues

Cost in

Component (Industrial Sector)

1977 dollars

Process Equipment

High Volatile Column (Other Fabricated Metal Products) 186,000

High Volatile Column Condenser (Plumbing and Heating Equipment) 18,600

High Volatile Column Vent Condenser (Plumbing and Heating Equipment) 55,800

$\begin{array}{lr}\text { High Volatile Column Reboiler (Metal Plate (Boilers)) } & \text { 279,000 }\end{array}$

Furfural Storage Tanks, $1 \times 10^{6} \mathrm{Gal}$ (2) (Other Structural

Metal Products)

Acetic Acid Storage Tank, 20,000 Gal (Other Structural Metal Products)

Methanol Storage Tank, 20,000 Gal (Other Structural Metal Products)

Methyl Acetate Storage Tank, 20,000 Gal (Other Structural Metal Products)

Residue Mills (2) (Spec. Industrial Machinery)

279,000

Sulfuric Acid Make-up Tanks, 25,000 Gal (2) (Other Fabricated Metal Products)

Rotary Acid Digester, 50,000 Gal (4) (Other Fabricated Metal Products)

Digester Surge Tank, 50,000 Gal (Other Fabricated Metal Products)

Screw Presses, 2,000 Tons/Day (4) (Spec. Industrial Machinery)

65,100

65,100

Steam Boiler (Metal Plate, Boiler Shop)

65,100

111,600

Stripping Column, 15-20 Plate (Other Fabricated Metal Products)

Stripping Column Condenser ( $P 1$ umbing and Heating Equipment)

167,400

Stripping Column Vent Condenser (Plumbing and Heating Equipment)

Stripping Column Reboiler (Metal Plate, Boiler Shop)

Furfural Decanter (Other Fabricated Metal Products)

Dehydrating Column (Other Fabricated Metal Products)

Dehydrating Column Vent Condenser ( $P$ lumbing and Heating Equipment)

Dehydrating Column Reboiler (Metal Plate, Boiler Shop)

$5,580,000$

139,500

744,000

651,000

279,000

232,500

55,800

837,000

279,000

465,000

162,750

530,100

Materials

Process Materials

Buildings and Auxiliaries

Transportation

$4,508,640$

$3,467,970$

$1,447,040$

Site and Preparation

559,000

Construction Labor $(220,363 \mathrm{hr}$ at

$\$ 11 / \mathrm{hr})$

$2,424,000$

Process Materials Labor $(271,181 \mathrm{hr}$

at $\$ 11 / \mathrm{hr}$ )

$2,983,000$

Process Equipment Labor $(101,727 \mathrm{hr}$

at $\$ 11 / \mathrm{hr})$

$1,119,000$

Home Office Expense

Field Office Expense

$5,780,000$

$3,729,000$

All Components

$37,266,000$ 
Table 3.12. Capital Expenditures and Materials Requirements for Model System for Hydrolysis of Corn Residues per $10^{12}$ Btu Output

\begin{tabular}{lrrr}
\hline & $\begin{array}{c}1977 \\
\text { Dollars }\end{array}$ & Deflator & $\begin{array}{c}1972 \\
\text { Dollars }\end{array}$ \\
\hline Total Capital Cost & $37,266,000$ & 1.28 & $29,114,063$ \\
Materials & $19,224,960$ & 1.28 & $15,019,500$ \\
Transportation & $1,447,040$ & 1.28 & $1,130,500$ \\
Construction Labor & $6,526,000$ & 1.28 & $5,098,438$ \\
Profit \& Overhead & $10,068,000$ & 1.28 & $7,865,625$ \\
Annual System 1012 Btu Output & & 0.936 \\
Total Capital Cost/1012 Annual Btu & & $\$ 31,104,768$ \\
Number of Years to Construct Facility & & 3 \\
Expected Life of Facility (years) & & $29+$ \\
Man-Years to Construct Facility & & 316.9 \\
Man-Years/1012 Btu Annual Output & & $300^{\circ}$ \\
Estimated Land Use (acres) & & \\
\hline
\end{tabular}

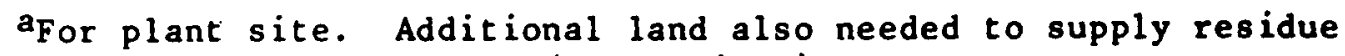
(approximately 0.25 acre/ton residue).

Table 3.13. Estimated Annual Operating Costs for Furfural Facility

\begin{tabular}{lc}
\hline \multicolumn{1}{c}{ Cost Element } & Millions of 1976 Dollars \\
\hline Sulfuric Acid & 0.175 \\
Utilities & 7.833 \\
Labor, 10 men per shift & 0.710 \\
Supervision, 20\% of labor & 0.142 \\
Maintenance Materials & 2.016 \\
Maintenance Labor & 1.120 \\
Malntenance Supervision & 0.224 \\
Payroll Burden & 0.659 \\
Supplies, 20\% of maintenance & 0.403 \\
materials & 1.846 \\
Indirect Costs & 1.120 \\
Taxes, Insurance & 16.248 \\
Total & \\
\hline
\end{tabular}

Source: ref. 31 . 


\subsection{SUMMARY OF FINDINGS}

The material; energy, residual, and cost inputs and outputs for this system have been calculated on the basis of $10^{12}$ Btu of output energy in the form of furfural. These results are summarized in Table 3.14. This system produces $0.94 \times 10^{12}$ Btu of chemical energy that. could substitute for refined petroleum products.

However, this process has the potential to double its energy generation by marketing its by-products (acetic acid, methanol, and methyl acetate). The water pollution load could be reduced if the spent acid and carbohydrate waste were used for fermentation of ethanol.

The off-side impacts resulting from residue removal could be more severe than the impacts from the operating residuals. Table 3.8 depicts the additional nutrient requirements to offset the losses from residue removal. These additional inputs total 63,073 tons. Coupled with an estimated 20\% increase in loss of nutrients from increased soil erosion, the impacts from corn residue utilization are greater for collection than for conversion. 
Tajle 3.14. Input/Output Summary of Furfural Production by Hyidrolyzis of Corn Residues

\begin{tabular}{|c|c|c|}
\hline 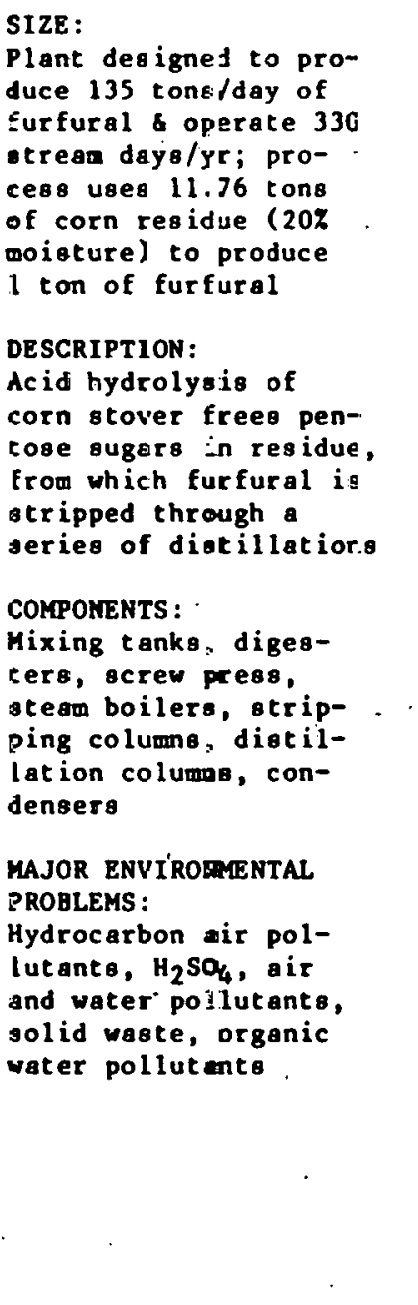 & 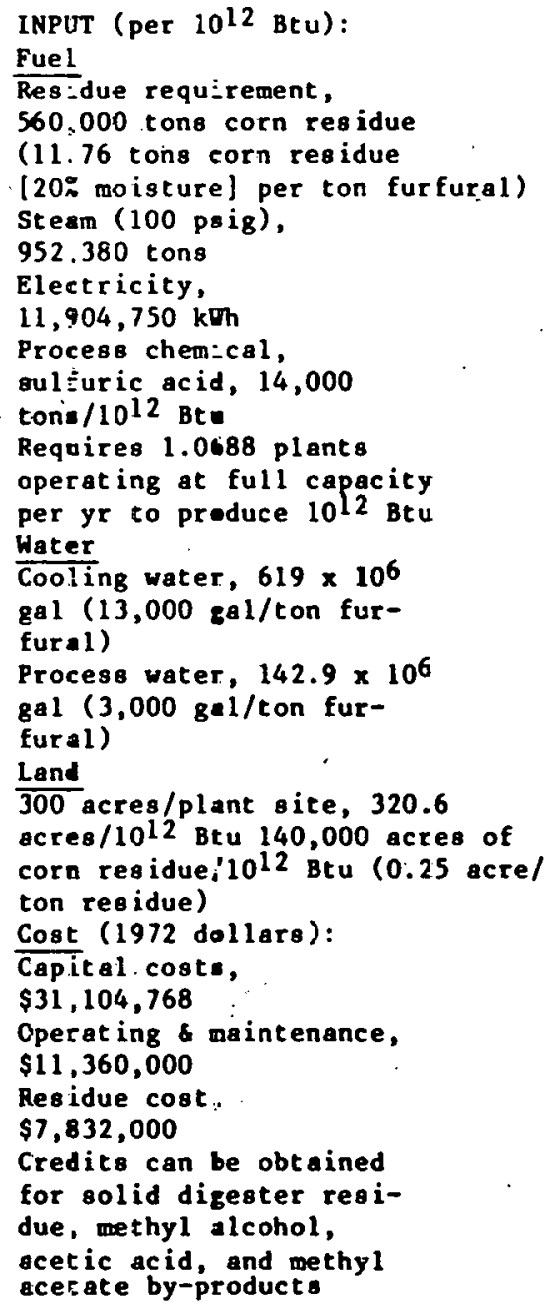 & 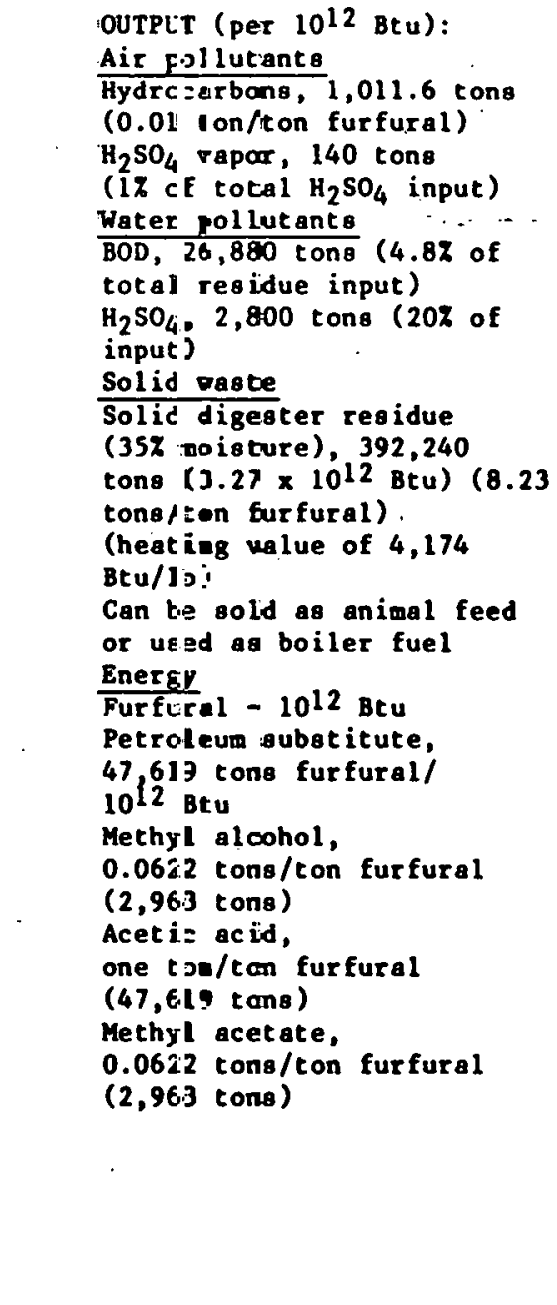 \\
\hline
\end{tabular}




\section{REFERENCES}

1. Quaker Oats Furfural -- General Information, Properties, Handling, Applications, Technical Bullet in 203C, Quaker Oats Chemical Division, Chicago, I11. (1974).

2.. Hitchcock, L.B., and H.R. Duffey, Comercial Production of Furfural in its 25th Year, Chemical Engineering Progress 44(9) 661-674 (1948).

3. Paturau, J.M., By-Products of the Cane Sugar Industry, El sevier, Amsterdam (1969).

4. Lipinsky, E.S., W.J. Sheppard, J.L. Ot is, E.W. Helper, T.A. McClure, and D.A. Scantland, Comprehensive Evaluation of Corm, Vol. 5, System Study of Fuels from Sugarcane, Sweet Sorghum, Sugar Beets, and Corn, Battelle Columbus Laboratories (1977).

5. Dunlop, A.P., and F.N. Peters, Jr., The Furans, ACS Monograph 119, Reinhold, New York (1953).

6. Kemp, L.C., G.B. Hamilton, and H.H. Grass, Industrial Engineering Chemistry $40,220 .(1948)$.

7. Peters, W.D., and R.S. Rogers, Hydrocarbon Processing, 47(11) (1968).

8. Norton, A.J., Industrial Engineering Chemistry 40, 236 (1948).

9. U.S. Department of Commerce, 1969 Census of Agriculture, Vol. 5, Part 15, Graphic Summary, U.S. Government Printing office Washington, D.C. (1974).

10. U.S. Department of Agriculture, Statistical Reporting Service, Agricultural Statistics 1977, Washington, D.C., (1977).

il. Arnold, L., The Comercial Utilization of Comstalks, Solid Wastes: Origin, Collection, Processing and Disposal, Wiley, New York (1975).

12. Dugas, D.J., Fuel from Organic Matter, Paper P-5100, Rand Corp., Santa Monica, Calif. (1973).

13. Larue, J.L., The Heat Value of Various Agricultural Crop Residues and Sewage Sludge Compost, National student Journal of American Society of Agricultural Engineers (1975).

14. Oursbourn, C.D., W.A. LePori, R.D. Lacewe11, K.Y. Lam, and O.B. Schacht, Energy Potential of Texas Crops and Agricultural Residues, Texas Agricultural Experiment Station, College station, Texas (Feb. 1978). 
15. Lipinsky, E.S., W.J. Sheppard, J.L. Otis, E.W. Helper, T.A. McClure, and D.A. Scant land, Conversion to Fuels and Chemical Feedstocks, Vol. 2, System Study of Fuels from Sugarcane, Sweet Sorghum, Sugar Beets and Corn, Battelle Columbus Laboratories (1977).

16. Faith, W.L., D.B. Keyes, and R.L. Clark, Industrial Chemicals, Wiley, New York, (1957).

17. Duffey, H.R., and P.A. wells, Jr., Economics of Furfural Production, Industrial and Engineering Chemistry 4?, 1408 (July 1955).

18. Furfural By-Products Technical Data, Technical Bullet in No. 164, Chemical Division, Quaker Oats Co., Chicago, I1l. (1972).

19. Brady, N.C., The Nature and Properties of Soils, Macmillan, New York, (1974).

20 Lyles, L., Possible Effects of Wind Erosion on Soil Productivity, lournal of Soil and Water Oünselvalion 30(6), 279-283 (19/3):

21. Tisdale, S.L., and W.L. Nelson, Soil Fertility and Fertilizers, Macmillan, New York (1975).

22. Adams, E.P., L.A. Derscheid, L.0. Fine, and M.S. Argabright, Do You Really Want to Remove Crop Residues? South Dakota Agriculture Experiment Station, Brookings, S.D. (1978).

23. Allison, F.E., Soil Organic Matter and its Role in Crop Production, Elsevier, Amsterdam (1973).

24. Larson, W.E., R.F. Holt, and C.W. Carlson, Residues for Soil Conser vation, Crop Residue Management Systems, W.R. Oschwald, Ed., Am. Soc. of Agronomy Spec. Pub. No. 31, pp. 1-15 (1978).

25. Pimentel, D., L.E. Hurd, A.C. Bellotti, M.J. Forster, I.N. Oka, O.D. Sholes, and R.J. Whitman, Food Production and the Energy Crisis, Science $182(4111), 443-449$ (1973).

26. Pimentel, D., World Food, Energy, Man and Environment, Energy, Agriculture and Waste Management, Proc. 1975 Cnrnell Agricultural Waotc Mgmt. Conf., Itaca, N.Y., Pp. 5-16 (1975).

27. Ode11, R.T and W.R. Oschwald, Productivity of ILlinois Soils, University of Illinois Cooperative Extension Service Circular 1016, Urbana, Illinois $(1970)$.

28. IlZinois Agronomy Handbook 1975, Cooperative Extension Service Circular 1104, University of Illinois College of Agriculture, Urbana-Champaign, I11. (1974). 
53

28. Iliznoir Agronomy Handbook 2975 , Cooperative Extension Service Circular 1104, University of Illinois College, of Agriculture, Urbana-Champaign, I11. (1974).

29. Carman, W.H., D.A. Williams, A.W. Tenne, and E.T. York, Jr., Our Land and its Care, Fertilizer Institute, Washington, D.C. (1952).

30. Morrison, F.B., Feeds and Feeding, Morrison Publishing Co., Clinton, Ia. (1959).

31. Lipinsky, E.S., J.J. Sheppard, J.L. Otis, E.W. Helper, T.A. McClure, and D.A. Scant land, Corn Agriculture, Vol. 4, System study of Fuels from Sugarcane, Sweet Sorghum Sugar Beets, and Corn, Battelle Columbus Laboratories, . (1977).

32. Perry, R.H., and C.H. Chiton, Chemical Engineers Handbook, McGrawHill, New York, (1973). 
54

THIS PAGE

\section{WAS INTENTIONALLY \\ LEFT BLANK}


4 CORN RESIDUE PYROLYSIS (GASIFICATION)

ABSTRACT

In this section capital and environmental costs are analyzed for energy recovery through pyrolysis of corn residues to produce a low-Btu fuel gas. The analysis is based on use of a gasification unit that would consume 1.17 tons/hr of corn residues to produce approximately $64,000 \mathrm{ft}^{3}$ of gas with a heating value of $150 \mathrm{Btu} / \mathrm{ft}^{3}$. The model system is designed to be used on large farms, where it would probably be used to supply gas for grain dryers. Use of such systems is commercially sound, but removal of corn residues rapidly depletes the soil, and extensive soil management would be necessary to maintain soil productivity. Air pollution is the major environmental problem associated with pyrolysis.

\subsection{INTRODUCTION}

\subsubsection{General System Description}

Pyrolysis is the thermochemical alteration of organic matter in the absence of air. The first material pyrolyzed by man most likely was wood, and the end-use energy produced was charcoal, a cleaner-burning fuel. This simple approach to pyrolysis is still one of the most widely practiced biomass conversion strategies in the world. Brazil has an intensive national program to increase charcoal production, and today $40 \%$ of the energy needs of the Brazilian steel industry (approximately 2 million tons annually) are supplied by charcoal.1

The principal products of pyrolysis are gas, a highly carbonized solid residue called char, and oil-1ike liquids with a high tar content. The proportions of char, oil, and gas produced depend on the chemical composition of the feed, its preparation, the reaction temperature and pressure, and the $t$ ime the material stays in the reactor. 2-5 Heat for pyrolysis may be externally applied to the biomass (true pyrolysis), or it may be produced by combustion of part of the biomass itself.

The modern method of charcoal production from wood is carried out in a steel retort. The wood is externally heated for $20-24 \mathrm{hr}$ at $500-700^{\circ} \mathrm{F}$ near atmospheric pressure. 6,7 The process is often referred to as destructive wood distillation because certain chemical products are produced in addition to charcoal. Distillation of one cord $(4,000 \mathrm{lb})$ of wood yields $7,000-12,000 \mathrm{ft}^{3}$ of condensable gas, 900-1,100 lb of charcoal, 200-300 gal of raw pyroligneous acid, and $2001 \mathrm{~b}$ of acetate of lime. 7

Liquefaction of biomaterials occurs at $400-700^{\circ} \mathrm{F}$ at pressures ranging from 1,000 psig to 4,000 psig. 8,10 Table 4.1 gives the percent conversion of some agricultural and forestry residues to oil. A typical catalyst used in this process is sodium bicarbonate. This process can produce an oil very similar to No. 6 fuel oil.1l The properties of the two oils are summarized in Table 4.2. 
Table 4.1. Conversion of Various Cellulosic wastes to ôja

\begin{tabular}{|c|c|c|c|c|c|c|}
\hline $\begin{array}{c}\text { Raw } \\
\text { Material }\end{array}$ & $\begin{array}{l}\text { Amount } \\
\text { (gm) }\end{array}$ & $\begin{array}{l}\text { Time at } \\
\text { Reaction } \\
\text { Temp. (hr) }\end{array}$ & $\begin{array}{l}\text { Maximum. } \\
\text { Pressure } \\
\text { (psig) }\end{array}$ & $\begin{array}{c}\text { Conver- } \\
\text { sion } \\
(\%)\end{array}$ & $\begin{array}{c}\text { Oil } \\
\text { Yield } \\
(\bar{z})\end{array}$ & $\begin{array}{c}\text { Co vied } \\
\left(g^{m} / 100 \text { gin }\right. \\
\text { oil }\end{array}$ \\
\hline $\begin{array}{l}\text { Cornstalks } \\
\text { Corncobs } \\
\text { Rice Hulls } \\
\text { Newsprint } \\
\text { Pine Bark }\end{array}$ & $\begin{array}{r}50 \\
100 \\
50 \\
50 \\
50\end{array}$ & $\begin{array}{l}1 \\
1 \\
1 \\
0.5 \\
1\end{array}$ & $\begin{array}{l}1,760 \\
2.400 \\
1,600 \\
1,640 \\
1,600\end{array}$ & $\begin{array}{l}95 \\
95 \\
97 \\
88 \\
83\end{array}$ & $\begin{array}{l}42 \\
38 \\
40 \\
40 \\
32\end{array}$ & $\begin{array}{c}21 \\
9.7 \\
25 \\
21 \\
45\end{array}$ \\
\hline
\end{tabular}

Source: ref. 11 .

${ }^{a} 200 \mathrm{ml}$ water, $10 \mathrm{gm} \mathrm{NaHCO}_{3}, 500$ psig initial co pressure, $250^{\circ} \mathrm{C}$ reaction temperatures.

Table 4.2. Properties of No. 6 Fuel Oil and a Typical. Pyrolytic Oil

\begin{tabular}{lcc}
\hline \multicolumn{1}{c}{ Property } & $\begin{array}{c}\text { No.6 } \\
\text { Fuel Oill: }\end{array}$ & $\begin{array}{c}\text { Pyrolytic } \\
\text { Oil }\end{array}$ \\
\hline Btu/1b & 18,200 & 10,500 \\
Specific gravity & 0.98 & 1.30 \\
Pounds per Gallon & 8.18 & 10.85 \\
Flash Point ( $\left.{ }^{\circ} \mathrm{F}\right)$ & 150 & 133 \\
Viscosity (SSU) at $190^{\circ} \mathrm{F}$ & 340 & 3,150 \\
Pumping Temperature ( $\left.{ }^{\circ} \mathrm{F}\right)$ & 115 & 160 \\
Atomization Temperature $\left({ }^{\circ} \mathrm{F}\right)$ & 220 & 240 \\
\hline
\end{tabular}

Source: ref. 11 .

Methane is the main gas component of pyrolysis if the reaction is carried out at high temperature and pressure. $\left(2,000^{\circ} \mathrm{F}, 1,000 \mathrm{psig}\right)$, and production can be boosted by injecting water into the reactor. 12 The water reacts with the hot char to produce carbon monoxide and hydrogen, and methane generation then proceeds by the following routes:

$$
\begin{gathered}
\mathrm{C}+2 \mathrm{H}_{2}-\mathrm{CH}_{4} \\
\mathrm{CO}+3 \mathrm{H}_{2}+\mathrm{CH}_{4}+\mathrm{H}_{2} \mathrm{O}
\end{gathered}
$$

Under even high pressure (up to 4,000 psig), methanol can be formed from the reaction. of carbon dioxide and hydrogen gas.13,14 The use of various chemical catalysts also can affect the volume and composition of gas produced. 15,16 
In this section, pyrolysis is examined for the production of a low-Btu fuei gas, of ten called producer gas; from corn residues under conditions of low pressure and relatively high temperature (about $1,600^{\circ} \mathrm{F}$ ). The reaction is actually a two-stage process in which part of the biomass in the reactor is combusted, with a limited air supply, to raise the temperature in the gasifier unit above $1,600^{\circ} \mathrm{F}$ to pyrolyze the remaining biomass. Steam is often injected to react with the char. to generate hydrogen and carbon monoxide gas. :

The composition of the gas produced by such a gasifier unit and that of a true pyrolysis gas is given in Table 4.3. The large amounts of nitrogen present in gasifier gas are from the air burned to increase the cemperature in the unit. It should also be noted that a gasifier converts eight to nine times more of the feedstock to gas than does pyrolysis.

Table 4.4 shows the char composition for different biomass feedstocks. The heating values of these pyrolytic chars range from 5,500 to $8,300 \mathrm{Btu} / 1 \mathrm{~b}$, similar to the heating values of many coals. The ash content reported in various chars from gasifiers is between $1 \%$ and $20 \% .17,18$ Tars are often generated in gasifiers, but the tar content is usually less than $5 \%$.

\subsubsection{Resource-Distribution...}

If corn residues are used to fire the gasifiers, the regional applications will presumably be located in the Corn Belt. The distribution of

Table 4.3. Characteristics of a True Pyrolytic Gas and Gasifier Gas

\begin{tabular}{|c|c|c|c|c|c|c|c|}
\hline \multirow[b]{2}{*}{ Characteristice } & \multicolumn{4}{|c|}{$\begin{array}{c}\text { Pyrolytic Gasa } \\
(\text { we } X)\end{array}$} & \multicolumn{3}{|c|}{$\begin{array}{c}\text { Gaoifier Gaob } \\
\left(V_{01} x\right)\end{array}$} \\
\hline & $\begin{array}{l}\text { Annual } \\
\text { Haste }\end{array}$ & $\begin{array}{r}\text { Rice } \\
\text { Hulls }\end{array}$ & $\begin{array}{l}\text { Grabo } \\
\text { Straw }\end{array}$ & $\begin{array}{r}\text { Fir } \\
\text { Bark }\end{array}$ & $\begin{array}{l}\text { Cubed Cotton } \\
\text { Gin Trash }\end{array}$ & $\begin{array}{l}\text { Raw Cracked } \\
\text { Walnut She } 118\end{array}$ & $\begin{array}{l}\text { Broken } \\
\text { Corncobs }\end{array}$ \\
\hline \multicolumn{8}{|l|}{ Componente } \\
\hline $\begin{array}{l}\mathrm{H}_{2} \\
\mathrm{CO} \\
\mathrm{CO}_{2} \\
\mathrm{CH}_{4} \\
\mathrm{C}_{2} \mathrm{H}_{2} \\
\mathrm{C}_{2}^{+} \\
\mathrm{THC} \\
\mathrm{H}_{2} \\
\mathrm{O}_{2} \\
\mathrm{H}_{2} \mathrm{~S}\end{array}$ & $\begin{array}{r}0.1 \\
21.9 \\
55.9 \\
6.1 \\
0.5 \\
1.8 \\
-- \\
-- \\
-- \\
7.8\end{array}$ & $\begin{array}{c}23.3 \\
28.5 \\
40.8 \\
3.5 \\
0.8 \\
0.8 \\
- \\
- \\
\overline{2.4}\end{array}$ & $\begin{array}{c}9.6 \\
53.9 \\
26.9 \\
3.8 \\
0.8 \\
2.8 \\
-- \\
-- \\
2.2\end{array}$ & $\begin{array}{r}6.3 \\
14.7 \\
64.7 \\
10.5 \\
1.0 \\
1.2 \\
-- \\
-- \\
-- \\
1.7\end{array}$ & $\begin{array}{l}18.3 \\
16.4 \\
11.6 \\
-- \\
- \\
1.8 \\
51.4 \\
0.5 \\
\ldots\end{array}$ & $\begin{array}{c}18.4 \\
20.2 \\
8.7 \\
-- \\
-- \\
-\overline{5.1} \\
47.3 \\
0.4 \\
--\end{array}$ & $\begin{array}{c}16.1 \\
18.7 \\
9.8 \\
- \\
- \\
-- \\
4.3 \\
50.9 \\
0.2 \\
--\end{array}$ \\
\hline \multicolumn{8}{|c|}{ Ocher Charocteriatice } \\
\hline $\begin{array}{l}\text { Bcu/ft } \\
\text { Gas Yield (z) } \\
\text { Char Yield (z) }\end{array}$ & $\begin{array}{l}226 \\
10.8 \\
48.1\end{array}$ & $\begin{array}{r}214 \\
12.1 \\
35: 9\end{array}$ & $\begin{array}{r}349 \\
5.2 \\
23.2\end{array}$ & $\begin{array}{r}222 \\
8.2 \\
41.2\end{array}$ & $\begin{array}{r}118 \\
88 \\
11\end{array}$ & $\begin{array}{r}159 \\
91 \\
9\end{array}$ & $\begin{array}{r}141 \\
93 \\
5\end{array}$ \\
\hline
\end{tabular}

Source: ref. 11.

bource: ref. 17. 
Table 4.4. Analysis of Pyrolytic Chars from Organic Solid Wastes

\begin{tabular}{lrcrr}
\hline Characteristics & $\begin{array}{c}\text { Animal } \\
\text { Waste }\end{array}$ & Rice Hulls & Fir Bark & Grass Straw \\
\hline Components (Wt \%) & & & & \\
$\quad$ Carbon & 34.5 & 36.0 & 49.9 & 51.0 \\
Hydrogen & 2.2 & 2.6 & 4.0 & 3.7 \\
Nitrogen & 1.9 & 0.4 & 0.1 & 0.5 \\
Sulfur & 0.9 & 0.1 & 0.1 & 0.8 \\
Oxygen & 7.9 & 11.5 & 24.3 & 19.2 \\
Ash & 48.8 & 49.2 & 21.4 & 24.3 \\
Btu/1b & 5,450 & $6,10 n$ & 8,260 & 8,300 \\
Char Yield (\%) & 48.1 & 35.9 & 41.6 & 23.2 \\
\hline
\end{tabular}

Source: ref. 11.

acreage planted to corn in the U.S. is presented in Fig.4.1. A three-state area in the Midwest (Illinois, Iowa, and Indiana) accounts for approximately $50 \%$ of the corn production in the U.S. 20

Average corn yields range from 2.7 to 3.08 tons/acre in 1976 , and average residue yields were estimated at between 2.89 and 3.3 tons/acre. Residue yields were calculated from grain yields using a ratio of $1: 1.07$, grain:residue, on a dry weight basis.21-24 Using this ratio, it is estimated that in 1976 over $90 \mathrm{million}$ tons of corn residues were generated in the above three midwestern states (see Table 4.5).

Since this area contains some of the world's most productive soils, it is ideal for evaluating the effects of total crop removal on the soil and the environment. Corn in this area is grown continuously or in rotation with soybeans. The yield per acre and the acreage in corn have steadily increased in recent years. 20 This trend will probably continue, but climatic and

Table 4.5. Corn -- Grain and Residue Production and Energy Value of Rasidues: Three Midweotern States and U.S., 1970

\begin{tabular}{|c|c|c|c|c|c|c|}
\hline Location & $\begin{array}{c}\text { Grain } \\
\text { (bushels/acre) }\end{array}$ & $\begin{array}{c}\text { Grain } \\
\text { (tons/acre) }\end{array}$ & $\begin{array}{l}\text { Reoiducb } \\
\text { (tons/acre) }\end{array}$ & $\begin{array}{c}\text { Total } \\
\text { Harvested } \\
\text { Acreagc } \\
\left(10^{3} \text { acres }\right)\end{array}$ & $\begin{array}{c}\text { Total } \\
\text { Reaidue } \\
\left(10^{6} \text { tons }\right)\end{array}$ & $\begin{array}{c}\text { Total } \\
\text { Energy } \\
\text { Yaluer? } \\
\left(10^{12} \text { Btu }\right)\end{array}$ \\
\hline Illinois & 107.0 & 3.00 & 3.21 & 11,690 & 37.5 & 413.5 \\
\hline Indiana & 110.0 & .3 .08 & 3.30 & 6,300 & 20.8 & 229.3 \\
\hline Iowa & 90.0 & 2.70 & 2.89 & 12,750 & 36.8 & 405.8 \\
\hline \multicolumn{7}{|l|}{ Three State } \\
\hline Total & - & - & -- & 30,740 & 95.1 & $1,048.6$ \\
\hline U.S. Total & 87.4 & 2.45 & 2.62 & 71,085 & 186.2 & $2,053.0$ \\
\hline
\end{tabular}

\footnotetext{
${ }^{a}$ Data from ref. 20 .

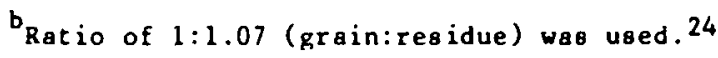

CBased on 5,513 Btu/1b (11.026 × $10^{\circ}$ Btu/ton. 25
} 


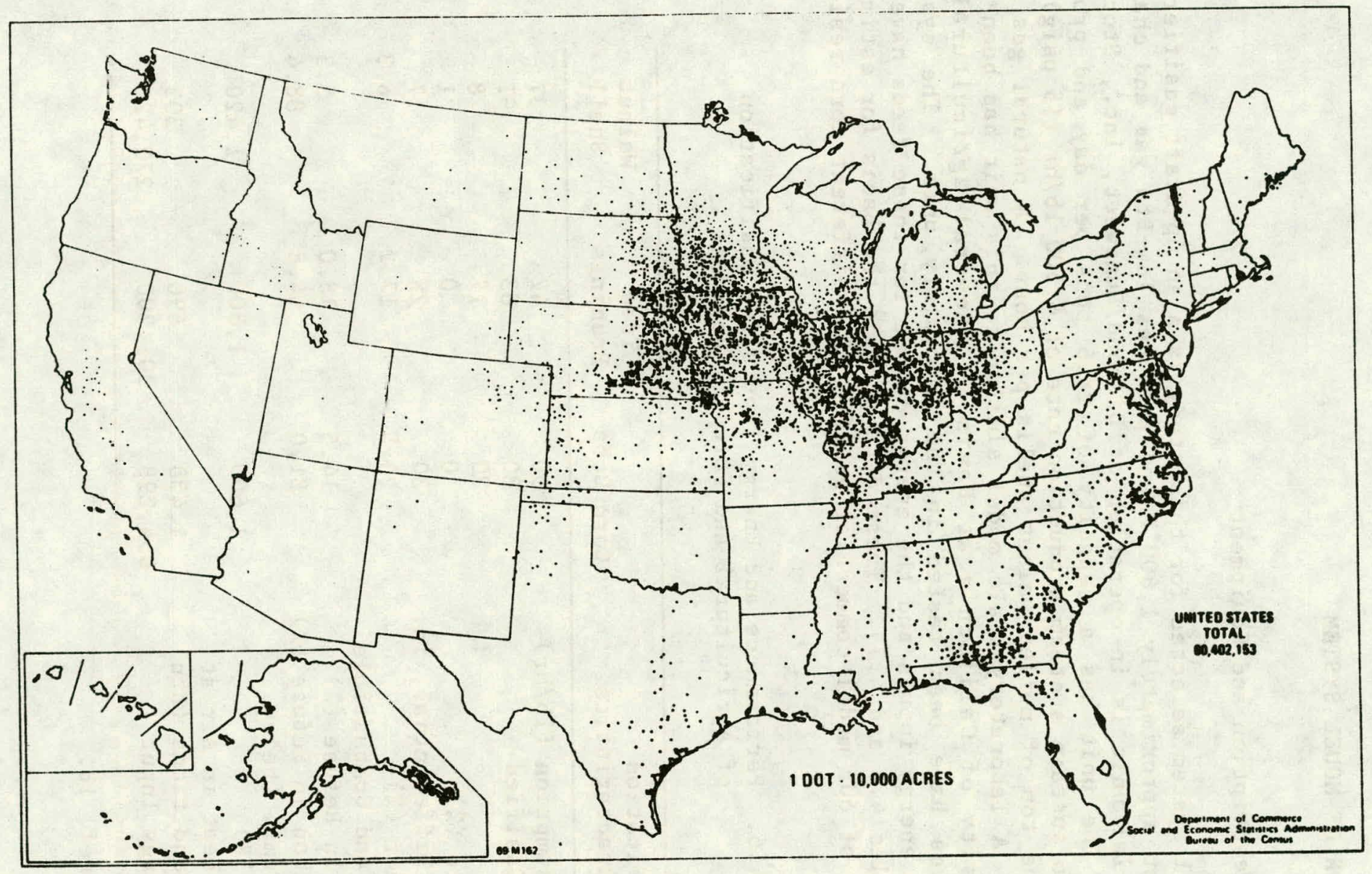

Fig. 4.1. Corn Harvested, 1969 
economic fluctuations must be taken into account. If corn and other crop residues are to be a viable biomass energy alternative in the Corn Belt, considerations must be given to the consequences of crop residue removal on soil quality in order to maintain land productivity.

\subsection{DESCRIPTION OF MODEL SYSTEM}

\subsubsection{System Description and Equipment}

The model system selected for this study is a an up-draft gasifier unit that operates at approximately $1,600^{\circ} \mathrm{F}$ and produces low-Btu gas and char. A similar commercial unit is in operation at Diamond/Sunsweet, Inc., Stockton, California. 26 The unit has a capacity of 28.6 tons per day and produces enough energy to sustain a steam production rate of $8,500 \mathrm{lb} / \mathrm{hr}(15 \mathrm{psig})$ at a fuel rate of one ton of mulled walnut shells per hour. A natural gas pilot flame is used. A laboratory-scale model similar to this unit has been built at the University of California at Davis.18 Several agricultural and forestry residues have been tested in the laboratory unit. The system's performance and energy inputs and the energy output for these feeds have been calculated (Tables 4.6 and 4.7). These data provide the basis for estimating the performance of our model commercial gasifier for different corn residues.

Table 4.6. Performance and Energy Inputs for Gasification of Agricultural and Forestry Residues

\begin{tabular}{lccr}
\hline \multicolumn{1}{c}{$\begin{array}{c}\text { Gasification } \\
\text { Characteristics }\end{array}$} & Corn Cobs & $\begin{array}{c}\text { Tree } \\
\text { Prunings }\end{array}$ & $\begin{array}{r}\text { Walnut } \\
\text { Shell }\end{array}$ \\
\hline Fuel Consumption (1b/hr) & 90 & 42 & 37 \\
Percent Gasified & 80 & 83 & 91 \\
Char (\%) & 20 & 17 & 8 \\
Condensate (\%) & 0 & 0 & 1 \\
Pressure Differential, in & 30 & 25 & 17 \\
Ash in Char (\%) & 4.5 & 17.2 & 6.3 \\
Volatile and Combustible & & 18.0 & 5.3 \\
$\quad$ Matter in Refuse (\%) & 81.0 & 64.8 & 88.4 \\
Fixed Carbon in Refuse (\%) & & & 1,420 \\
Firebox Temp. (below & & & \\
chuke, ${ }^{\circ}$ ) & 1,600 & 1,800 & 303 \\
Scnsible Hcat in Air at & 1,438 & 690 & 270,421 \\
$\quad$ Input Conditions (Btu) & 654,298 & 301,200 & \\
Total Energy Input & & & \\
\hline
\end{tabular}

Source: ref. 18. 
Chopped cornfield residue would be the feedstock for the unit. Fiftyfive percent of the input is gasified, and the principal by-product is a lowBtu gas $(100-200 \mathrm{Btu} / \mathrm{scf})$ with a char residue ( $30 \%$ of input energy) as a byproduct. The remaining heat is not recovered. When corncobs are used the heating value of the dry fuel is approximately $7,254 \mathrm{Btu} / 1 \mathrm{~b}$. The mean heating value for dry corn residue (leaf, husk, cob, and stalk) is 7,268 Btu/ $1 \mathrm{~b} .21$

Table 4.7. Energy Outputs from Gasification of Agricultural and Forestry Residues

\begin{tabular}{|c|c|c|c|}
\hline $\begin{array}{l}\text { Energy Output } \\
\text { Characteristics }\end{array}$ & $\begin{array}{l}\text { Corn } \\
\text { Cobs } \\
(B \leftarrow u / h r)\end{array}$ & $\begin{array}{l}\text { Tree } \\
\text { Prunings } \\
\text { (Btu/hr) }\end{array}$ & $\begin{array}{l}\text { Walnut } \\
\text { Shells } \\
\text { (Btu/hr) }\end{array}$ \\
\hline $\begin{array}{l}\text { Heat of Combustion of } \\
\text { Solid Refuse }\end{array}$ & 16,890 & 8,321 & 1,015 \\
\hline $\begin{array}{l}\text { Volatile and Combusti- } \\
\text { ble Matter, Fixed } \\
\text { Carbon }\end{array}$ & 211,410 & 67,087 & 37,941 \\
\hline Sensible Heat in Char & 6,588 & 2,613 & 1,083 \\
\hline $\begin{array}{l}\text { Heat of Combustion of } \\
\text { Anhydrous tar in } \\
\text { Condensate }\end{array}$ & 0 & 0 & 1,396 \\
\hline $\begin{array}{l}\text { Latent and Sensible } \\
\text { Heat of Water in } \\
\text { Condensate }\end{array}$ & 0 & 0 & 244 \\
\hline Radiant Heat & 40,000 & 40,000 & $.40,000$ \\
\hline Total & 274,897 & 118,021 & 81,679 \\
\hline $\begin{array}{l}\text { Total Energy. Output } \\
\text { in Gas }\end{array}$ & 379,401 & 183,179 & 188,742 \\
\hline $\begin{array}{l}\text { Sensible and Latent } \\
\text { Heat of Steam in Gas } \\
\text { Stream }\end{array}$ & 8,352 & 4,043 & 3,905 \\
\hline $\begin{array}{l}\text { Sensible Heat in Dry } \\
\text { Gas }\end{array}$ & 9,882 & 4,660 & 4,622 \\
\hline Total & 18,234 & 8,703 & 8,527 \\
\hline $\begin{array}{l}\text { Net Energy Output in } \\
\text { Cas }\end{array}$ & 361,167 & 174,475 & 130,214 \\
\hline $\begin{array}{l}\text { Conversion Efficiency } \\
(\%)\end{array}$ & 55.2 & 57.9 & 66.6 \\
\hline
\end{tabular}

Source: ref. 18 . 
The data presented for the laboratory gasifier with corncobs should be fairly close to the results for actual corn residue; but the fuel consumption rate will be somewhat higher (i.e., more moist corn residue will be required to realize the wet fuel heat potential). The increase in fuel consumption can be approximated by the following formula:

$$
\text { Wet Fuel Consumption }=\frac{\text { Dry Fuel Consumption }}{1.0-\text { Fraction of } \mathrm{H}_{2} \mathrm{O}} \text { in Residue }
$$

It should be noted that a wetter fuel will also affect reactor efficiency.

\subsubsection{Energy and Material Flows}

The major material and energy flows for out model gasification oystem are given in Table 4.8. The model system is small, so it may be used on the farm near the site of production to reduce the cost of the corn residue fuel. Although the low-Btu gas could be used to operate machinery, such as irrigation pumps, the primary application for this unit probably would be to supply gas tor grain dryers.

\subsection{ENVIRONMENTAL DATA}

\subsubsection{General Soil Effects}

Total removal of residues from corn, wheat, and cotton fields has the same ultimate effect on the soil although the rate will vary because of differences in crop root systems, plant physiology, climatic conditions, and soil properties. Soil destruction begins with the first harvest of residue because the soil is completely exposed to water and wind. Brady27 report's

Table 4.8. Material and Energy Flows for Gasificationa of Corn Residues at $20 \%$ Moisture

\begin{tabular}{|c|c|c|}
\hline System Variable & $\begin{array}{l}\text { Macerial } \\
\text { Flow }\end{array}$ & $\begin{array}{l}\text { Energy } \\
\text { Flow }\end{array}$ \\
\hline $\begin{array}{l}\text { Residue Utilization } \\
\text { Rate }\end{array}$ & $\begin{array}{l}1.5 \text { Tons (corn resi- } \\
\text { due) } / \mathrm{hr}\left(20 \% \mathrm{H}_{2} \mathrm{O}\right)\end{array}$ & $\begin{array}{l}17.4 \times 10^{6} \\
\text { Btu/hr }\end{array}$ \\
\hline Utilities & $\overline{-}$ & $\begin{array}{l}120 \mathrm{kWh} / \mathrm{day} \\
10 \mathrm{gallons} \\
\text { gasoline/day } \\
\text { natural gas } \\
\text { equivalent }\end{array}$ \\
\hline Production Efficiency & $\begin{array}{l}64,000 \mathrm{CL}^{3}(\mathrm{Gas} / \mathrm{hr} \\
\left(150 \mathrm{Btu} / \mathrm{ft}^{3}\right) \\
0.18 \mathrm{tons}(\mathrm{Char}) / \mathrm{hr} \\
(14,500 \mathrm{Btu} / 1 \mathrm{~b})\end{array}$ & $\begin{array}{l}9.6 \times 10^{6} \\
\text { Btu/hr } \\
5.2 \times 10^{6} \\
\text { Btu/hr }\end{array}$ \\
\hline
\end{tabular}

aplant Capacity: 24-hr/day, 330 stream days/yr. 
that Wischmeir and Mannering found that removing residues increased runoff from 0.52 inch to 0.98 inch on 678 plot-years of corn. When residues are removed, the raindrop effect destroys surface soil structure, causing puddling, decreased water infiltration, soil compaction, reduced porosity, and a loss of organic matter. In wheat and cotton growing areas, wind takes over after the soil has dried. Wind sorts the surface material, blowing away the fines and leaving only the semisterile skeletal matter. 28

Organic matter acts as a binding agent to develop and maintain soil structure, by maintaining good tilth, increasing infiltration, maintaining soil porosity, and acting as a counter force against soil compaction.27,29 Organic matter also serves as a storehouse for nutrients, increases cation and anion exchange capacity, and chelates micronutrients, protecting the plant from potentially toxic concentrations.27,29-31 In high-organic-matter soils this material releases $40-80$ lb/acre of nitrogen for crop uses. 30,31 Removal of all residues from fields where continuous corn was grown during a period of 18 years resulted in a $15,000 \mathrm{lb} /$ acre decrease in organic matter. 30

Not all residues need to be returned to the soil to maintain organic carbon content. Larson and others 32 found that by using conservational tillage (e.g., chisel plow) $1 \%$ to $57 \%$ of the corn area in selected 1 and resource areas of Minnesota and Iowa could have all the residues removed without losing more than 4 tons of soil per acre per year. However, these are only calculated data; the amount of residues that can be safety removed from an area depends on the soil, climatic conditions, and especially management practices such as type of tillage and fertility program. 32

The adverse effect of removing corn residues on the chemical properties of soil can be partially overcome by increased fertilizer application. Data presented in this report are only for the first year that crop residues are removed. In the second crop year, fertilizer rates must be increased to replace that portion of the nutrients removed with the grain, residue, and erosion. Maintaining favorable chemical. properties over a period of several crop years could be more costly in terms of energy than the amount of energy in the residue. Unfortunately, the adverse impact on the physical properties of soil can only be slowed down with higher fertilizer rates. The continual passage of crop residues through the soil and their transformation into organic matter are needed to stop the deterioration of the physical properties.of the soil.29,31

\subsubsection{Some Aspects of Corn 'Residue Removal}

Table 4.9 shows the inputs needed to obtain a yield of 107 bushels/ acre of corn. Data taken from Pimentel et al.33 were adjusted to reflect the increased yield in our table. The assumption that a linear relationship exists between fertilizer rates 36 and yield made calculation of the nutrient data possible.

The amount of fertilizer nitrogen applied to the soil for corn production is based on maximum economic return. 36 other nutrients (phosphorus and potassium) are added on the basis of soil tests that indicate the amount of nutrient needed for maintenance of optimum crop yield plus a build-up factor that provides for fixation of these nutrients by soils that are low in these elements. Calcium and magnesium are seldom required for Illinois soils. 
These soils are rich in basic cations; however, the advent ot continuous corn production with high rates of applied nitrogen fertilizer made the addition of agricultural lime necessary to maintain $a$ pH of 6.5 in the surface soil horizon.

Table 4.10 shows the approximate amounts of nutrients removed in the grain and residue. When only the grain is removed, the fertilizer added to produce this crop (Table 4.9) is adequate to maintain the productivity of the soil; however, the loss of nutrients by erosion (Table 4.11) eliminates most of the build-up fertilizer applied. Also, the material eroded away usually contains a high proportion of nutrients that are readily available to plants; in some experiments the material eroded away contained five times more organic matter and nitrogen than the original soil. 27

Data in Tables 4.10 and 4.11 show that nutrient losses greatly increase because erosion increases and that nutrients. in crop residues are also lost when these residues are completely removed. Nitrogen losses are 1.6 times greater than the amount applied, and phosphorus losses are 1.2-1.6 times greater than the amount applied. Potassium losses are 10.6-16.7 times greater than the amount applied, and magnesium losses are 130-200 times greater. Calcium losses are high because of erosion, but the total calcium loss is not greater than the amount applied. No sulfur is applied unless a deficiency is noted; however, at the rate of removal indicated in Tables 4.10 and 4.11 it will not take many growing seasons for sulfur deficiencies to appear in corn plants. Trace elements are not normally added to the soil as fertilizer, but sprayed on the growing plants when deficiency. symptoms become evident. Some soils already exhibit deficiencies in sulfur and some of the trace elements; 36 therefore a management system in which corn is grown in monoculture and the total crop is removed will only increase the number of acres that must have these nutrients supplied by fertilizers. There are additional losses of nutrients, particularly nitrogen, by the

Table 4.9. Inputs per Year Needed to Obtain a Yield of 107 Bushels of Corn and 3.21 Tons of Residue per Acre under Continuous Cropping Systems in Illinois

\begin{tabular}{lcc}
\hline Input & $\begin{array}{c}\text { Amount } \\
\text { per Acre }\end{array}$ & $\begin{array}{c}\text { Amount per Ton } \\
\text { of Residue }\end{array}$ \\
\hline Nutrients (lb) & & \\
$\quad$ Nitrogen & 148 & 46.1 \\
Phuspliotus & 41 & 12.8 \\
Potassium & 79 & 24.6 \\
Calcium & $634^{\mathrm{a}}$ & 197.8 \\
Magnesium & 1 & 0.33 \\
Seed (1b) & 19 & 5.9 \\
Active Ingredients & & 0.93 \\
in Pesticides (1b) & 3 & 6.9 \\
Gasoline (gal) & 22 & \\
\hline
\end{tabular}

Data sources: refs. 33-36.

ayearly rate assuming that soils are limed every fourth year. 
Table 4.10. Nutrients and Mineral Matter Removed by Corn Cropa

\begin{tabular}{lccccc}
\hline & \multicolumn{2}{c}{ Grain } & & \multicolumn{2}{c}{ Residue } \\
\cline { 5 - 6 } $\begin{array}{l}\text { Elements and } \\
\text { Minerals }\end{array}$ & $\begin{array}{c}\text { Pounds } \\
\text { per Acre }\end{array}$ & $\begin{array}{c}\text { Pounds per } \\
\text { Ton of orain }\end{array}$ & & $\begin{array}{c}\text { Pounds } \\
\text { per Acre }\end{array}$ & $\begin{array}{c}\text { Pounds per } \\
\text { Ton of Residue }\end{array}$ \\
\hline Nitrogen & 96 & 32.0 & & 71.3 & 22.2 \\
Phosphorus & 16.6 & 5.5 & & 11.4 & 3.6 \\
Potassium & 23.6 & 7.9 & & 85.8 & 26.8 \\
Calcium & 11.4 & 3.8 & & 19.6 & 6.1 \\
Magnesium & 14.0 & 4.7 & 12.1 & 3.8 \\
Sulfur & 10.2 & 3.4 & 7.0 & 2.2 \\
Copper & 0.04 & 0.013 & & 0.04 & 0.012 \\
Manganese & 0.06 & 0.020 & & 1.07 & 0.334 \\
Zinc & 0.11 & 0.037 & & 0.21 & 0.066 \\
Mineral Matter & - & - & 371.9 & 116.0 \\
\hline
\end{tabular}

Data sources: refs. $29,37,38$.

aThe assumption. was made: that a linear relationship exists between crop yield and nutrient application; therefore the data were adjusted for a yield of 107 bushels/acre.

Table 4.11. Nutrients.Lost by Soil Erosion under Continuous Corn Production with Two Residue-Management Techniquesa

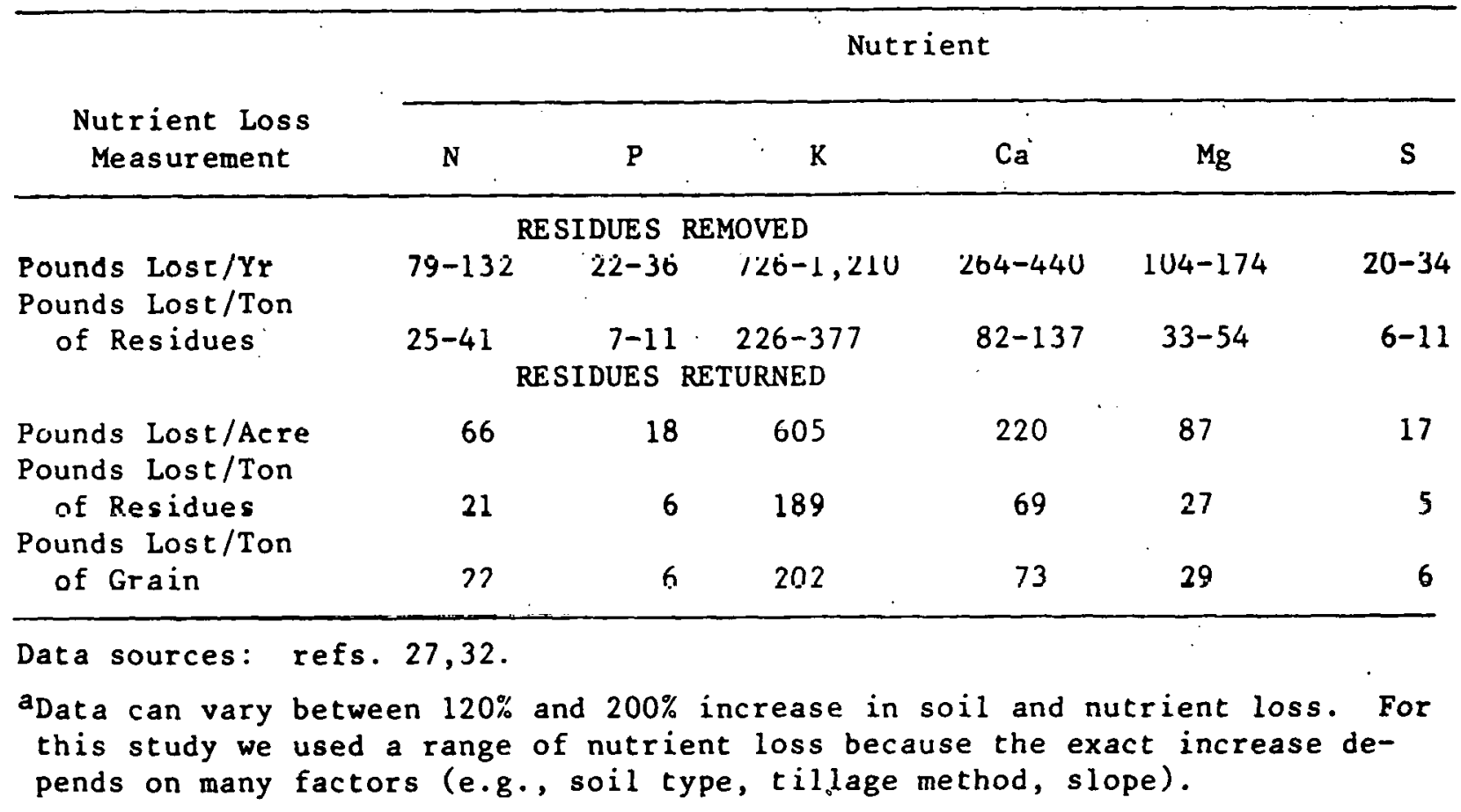


leaching process. Nutrients move down through the soil out of the root zone and are no longer available to corn plants. Table 4.12 gives the nutrient replacement required by residue removal per ton of residue removed and per $10^{12}$ Btu generated by corn residue gasification.

\subsubsection{Operating Residuals}

The major environmental problem associated with pyrolysis is air pollution. The oil and char produced have been marketable in the past ${ }^{7}$ and may be considered by-products instead of pollutants. Although-negligible amounts of oil and $t a r$ are expected to be generated during gasification of corn residue, a significant quantity of combustible solid waste is generated. It is estimated that 18,750 tons of char (heating value $29 \times 10^{6} \mathrm{Btu} / \mathrm{ton}$ ) is produced per $10^{12}$ Btu output. This solid waste should have market value as a solid'fuel.

There are three major air pollutants: $\mathrm{NO}_{x}$, particulates, and hydrogen sultides. In experiments on gasifier emissions using wood residues, Hodam and Williams 17 measured emissions of $0.703 \mathrm{lb} / \mathrm{hr}$ of particulates and $\mathrm{NO}_{x}$ at $129 \mathrm{ppm}$. We have estimated these $\mathrm{NO}_{x}$ emissions to be about $1 \mathrm{lb} / \mathrm{hr}$ and assume that data for wood residues are applicable to corn residues. A review of pyrolysis by Nelson and Loehr 39 suggests that $25-30 \%$ of the sulfur goes into hydrogen sulfide, the third major air pollutant. Together with our data, this suggests that from one wet ton of corn residue $(2.2$ ib sulfur/ton) at $25 \%$ conversion of the sulfur to $\mathrm{H}_{2} \mathrm{~S}, 0.55$ lb of sulfur or $0.59 \mathrm{lb}$ of $\mathrm{H}_{2} \mathrm{~S}$ are emitted per ton of residue (20\% moisture content). This amounts to 46.1 tons of $\mathrm{H}_{2} \mathrm{~S}$ per $10^{12} \mathrm{Btu}$ of end-use energy. The $\mathrm{H}_{2} \mathrm{~S}$ from pyrolysis is mostly. converted to $\mathrm{SO}_{2}$ during combustion of the gas. In the same terms, about 36.6 tons of particulates and about 52.1 tons of $\mathrm{NO}_{\ddot{x}}$ are emitted per $10^{12}$ Btu of end-use energy.

\subsubsection{Land Requirements}

The amount of land required for the conversion facility is small --

0.25 acre. However, the amount of land required for residue production is quite large, approximately 0.25 acre/ton.

Table 4.12.. Nutrient Replacement Required when Corn Residue is Removed for Pyrolysis

\begin{tabular}{lcc}
\hline Nutrient & $\begin{array}{l}\text { Replacement per Ton } \\
\text { of Residue (20\% mois- } \\
\text { ture) (tons/ton) }\end{array}$ & $\begin{array}{l}\text { Replacement per } \\
1012 \text { Btu } \\
\text { (tons/1012 Btu) }\end{array}$ \\
\hline Nitrogen & 0.0185 & 2,891 \\
Phosphorus & 0.0051 & 797 \\
Potassium & 0.0099 & 1,547 \\
Calcium & 0.079 & $:$ \\
Magnesium & 0.00013 & 20 \\
\hline
\end{tabular}




\subsubsection{Water' Requirements}

No water requirements are anticipated for the gasification of corn residues.

\subsection{ECONOMIC DATA}

\subsubsection{Capital Cost8}

The system described for the gasification of corn residue is quite simple: a gasifier unit, a materials handling unit, and the gasifier with piping and controls. The gasifier has a dry-fuel rating of 28.6 tons/day ( 330 stream days/yr). Tables 4.13 and 4.14 identify and oumarize the capital costs of the system for major equipment purchases and per 1012 Btu output.

The total estimated capital cost for this system is $\$ 112,042$ (1972 dollars) per $10^{12}$ Btu of output.

\subsubsection{Operating and Maintenance Costs}

Labor cost as a percentage of process equipment cost is taken at $9 \%$, and overhead and profit are $10 \%$ of the materials subtotal.

Annual labor (1977) and maintenance costs for this unit have been cálculated by $\operatorname{Goss}^{26}$ as follows:
- Annual labor $(1,000 \mathrm{hr}$ at $\$ 10 / \mathrm{hr})$
$\$ 10,000$
- Repairs and Maintenance ( $3 \%$ of new cost)
$\$ 4,800$

To these expenses should be added:

- Supervision ( $20 \%$ of labor)

$$
\text { \$ } 2,000
$$

- Overhead (60\% of labor plus supervision)

$\$ 7,200$

- Residue Cost (80\% dry) (11,800 tons/yr at

$\$ 237,600$. $\$ 20 /$ ton)

The residue cost is taken from the low estimate made by Lipinsky et al.25 for field-dried chopped corn residue. The removal of this much residue would require 220 additional tons of nitrogen, 61 tons of phosphorus, and 117 tons of potassium. Lipinsky et al, considered the fertilizer value of the corn in their estimate although not necessarily in those quantities.

\subsection{SUMMARY OF FINDINGS}

The material, energy, residual, and cost inputs and outputs for this system have been calculated on the basis of $10^{12}$ Btu of energy output from the gasifier. These results are summarized in Table 4.15. It would require 13.2 systems to produce $10^{12}$ Btu. 
Table 4.13. Construction Costs for a Gasification Unit

\begin{tabular}{|c|c|}
\hline Component (Industrial Sector) & $\begin{array}{c}\text { Cost in } \\
1977 \text { Dollars }\end{array}$ \\
\hline $\begin{array}{l}\text { Gasifier, } 28.6 \text { Tons/Day (Fabricated Metal Product) } \\
\text { Piping, Burner, and Controls (Plumbing and Heating Equipwent) } \\
\text { Storage Bin, } 12 \text { Ft } x 35 \mathrm{Ft} \text { (Fabricated Metal Product) } \\
\text { Conveyor Unit (Material Handling Machinery) } \\
\text { Labor, } 932 \mathrm{Hr} \text { at } \$ 13 / \mathrm{Hr} \\
\text { Transportation } \\
\text { Overhead and Profit } \\
\text { Total }\end{array}$ & $\begin{array}{r}79,794 \\
37,200 \\
6,138 \\
2,083 \\
12,116 \\
9,425 \\
13,464 \\
160,220\end{array}$ \\
\hline
\end{tabular}

Table 4.14. Capital Costs of a Gasification Unit per $10^{12}$ Btu Output

\begin{tabular}{lrrr}
\hline & 1977 & & 1972 \\
& Dollars & Deflator & Dollars \\
\hline Total Capital Cost & 160,220 & 1.43 & $112,042$. \\
Materials & 125,215 & 1.43 & 87,563 \\
Transportation & 9,425 & 1.43 & 6,593 \\
Construction Labor & 12,464 & 1.43 & 8,473 \\
Profit and Overhead & 13,464 & 1.43 & 9,415 \\
Annual System 1012 Btu Output & & 0.07575 & \\
Total Capital Cost/1012 Annual Bti & & $1,479,102$ & \\
Number of Years to Construct Facility & & 1 & \\
Expected Life of Facility (years) & & 10 & \\
Man Years to Construct Facility & & 0.466 & \\
Man Years/lol2 Btu Annual Output & & 0.15 & \\
Estimated Land Use (acres) & & 0.259 & \\
\hline
\end{tabular}

${ }^{a_{F}}$ or one plant site. Additional land also needed to supply residue (approximately 0.25 acre/ton residue): 
Table 4.15. Input/Output Summary for Pyrolys is of Corn Residues

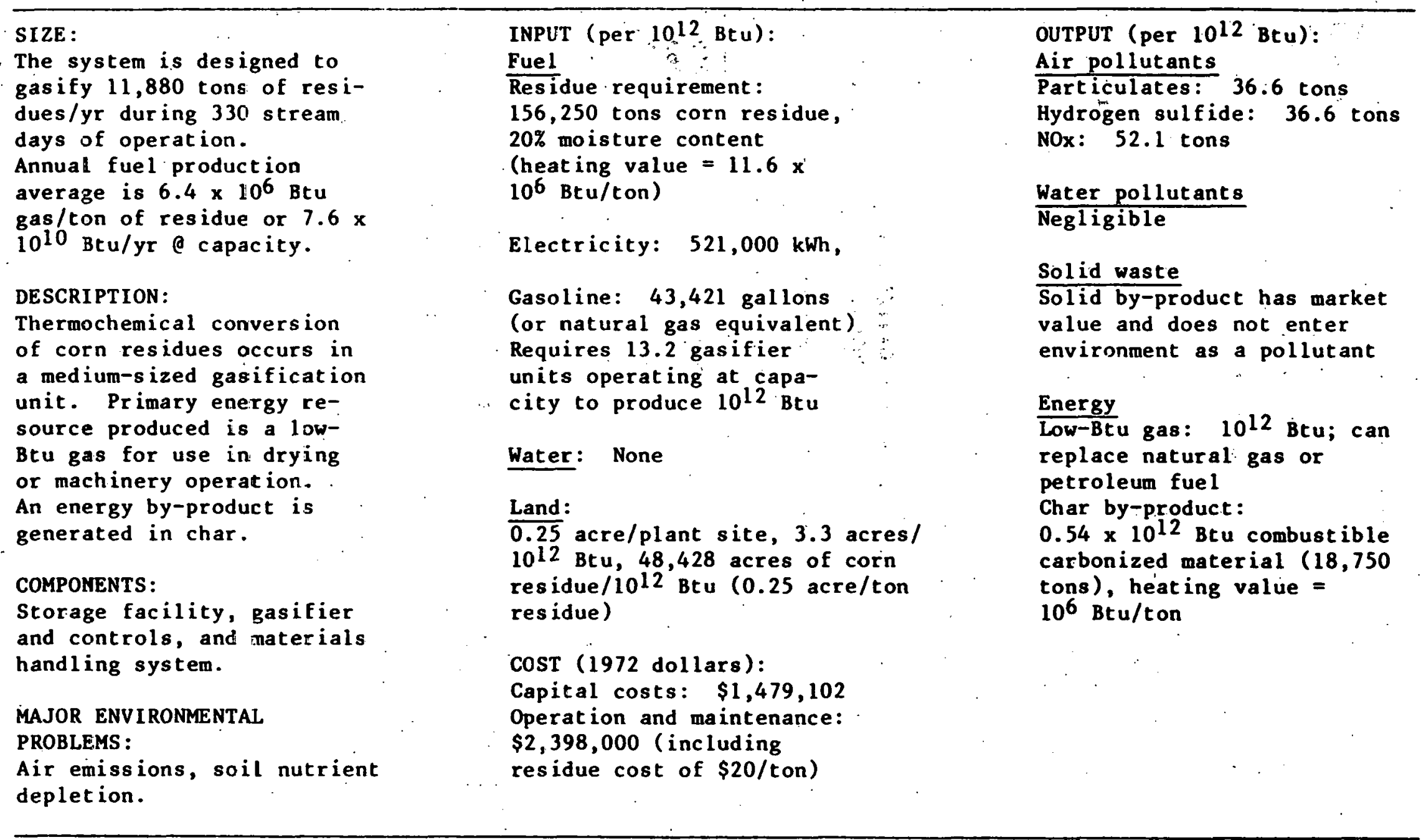




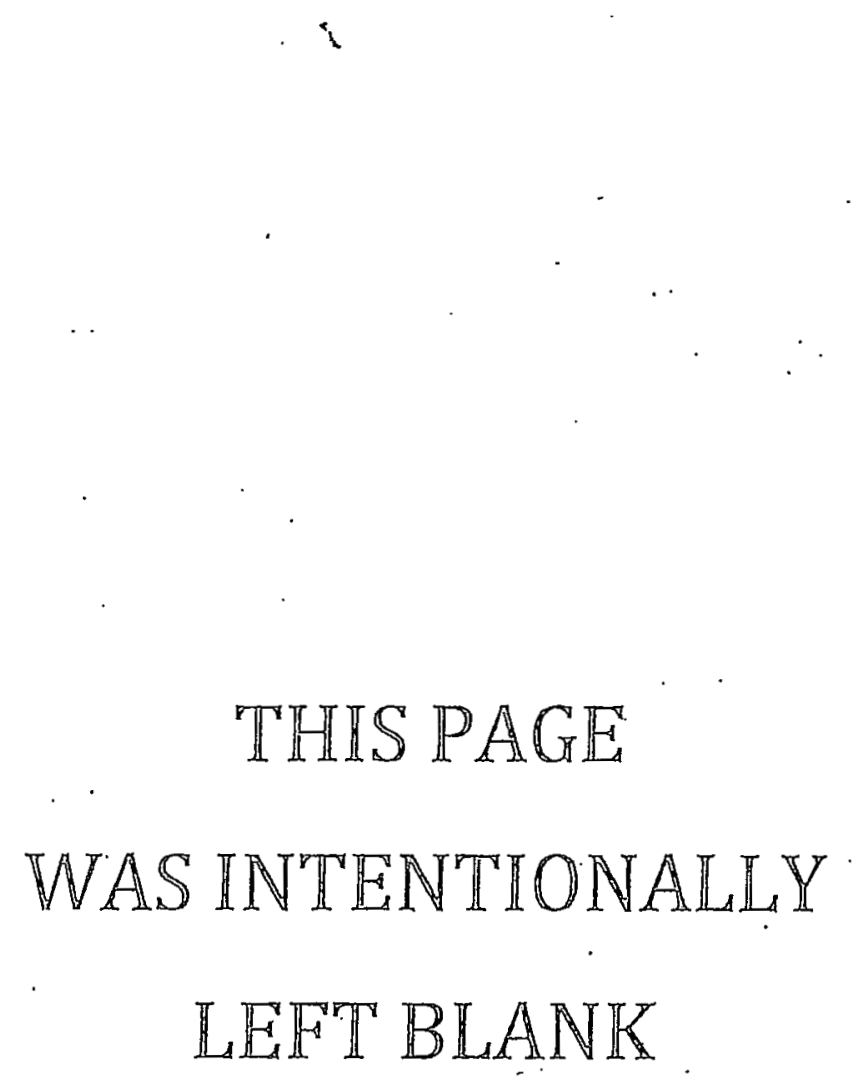




\section{REFERENCES}

1. Goldemberg, J., Brazil: Energy Options and Current Outiook, Science, 200 (April 14, 1978).

2. Brink, D.L., J.F. Thomas, and G.W. Faltico, The Pyrolysis GasificationCombustion Process: Energy Effectiveness Using Oxygen v6. Air with WoodFuel Systems, Fuels and Energy from Renewable Resources, Academic Press, New York (1977).

3. Garrett, D.E., Conversion of Biomass Materials into Gaseous Products, Proc. Second Annual Fuels from the Biomass Symp., Troy, N.Y.(1978).

4. Solar Program Assessment: Environmental Factors -- Fuels from Biomas6, ERDA 77-47/7, (1977).

5. Retrofit '79, Proceedings of a Workshop on Air Gasification, Sponsored by Solar Energy Research Institute, Seattle, Washington, February 2, 1979.

6. Sittig, M., Environmental Sources and Emissions Handbook, Noyes Data Corp., Park Ridge, N.J., pp. 519-521 (1975).

7. Shreve, R.N., Chemical Process Industries, McGraw-Hil1, New York (1967).

8. Appell, H.R., The Production of Oil from Wood Waste, Fuels from Waste, Academic Press; New York (1977).

9. Shafizadeh, F., Fuels from Wood Waste, Fuels from Waste, Academic Press, New York (1977).

10. Biomass Liquefaction Program -- Experimental Investigations at Albany, Oregon, Proc. Second Annual Fuels from the Biomass Symp., Troy, N.Y., (1978).

11. Pober, K.W., and H.F. Bauer, The Nature of Pyrolytic Oil from Municipal Solid Waste, Fuels from Waste, Academic Press, New York (1977).

12. Huebler, J., F.C. Schora, and B.S. Lee, The Hygas Coal Gasification Proce66, Energy Technology Handbook, D.M. Considine, Ed., McGraw-Hill, New York (1977).

13. Haider, G., Methanol Production from Organic Waste, Academic Prese, New York (1977).

14. Wan, E., A Plan for the Introduction of Biomass Based Methanol into the Energy Economy, Proc. Second Annual Fuels from the Biomass Symp., Troy, N.Y. (1978). 
15. Conversion of Forest Residues to a Methane-Rich Gas, Proc. Second Annual Fuels from the Biomass Symp., Troy, N.Y:(1978).

16. Walkup, D.C., L.K. Mudge, J.L. Coy, L.J. Sealock, and R.J. Robertus, Investigation of Gasification of Biomass in the Presence of Multiple Catalysts, Proc. Second Annual Fuels from the Biomass Symp., Troy, N.Y., (1978).

17. Hodam, R.H., and R.O. Williams, Small Scale Gasification of Biomass to Produce a Low Btu Gas, IGT Energy from Biomass and Waste Conference, Washington, D.C.(1978).

18. Williams, R.O., and B. Horsfield, Generation of Low-Btu Fuel Gas from Agricultural Residue Experiments with Laboratory Scale Production, in Food, Fertilizer, and Agricultural Residues, R.C. Loehr (ed), Ann Arbor, Michigan (1977).

19. U.S. Department of Commerce, 1969 Census of Agriculture,vol. 5, Special Reports; Part 15, Graphic Summary, U.S. Government Printing Office Washington, D.C. (1973).

20. U.S. Department of Agriculture, Statistical Reporting Service, Agricultural Statistics 1977 , Washington, D.C., (1977).

21. Arnold, L., The Commercial Utilization of Comstalks, Solid Wastes: Origin, Collection, Processing and Disposal, Wiley, New York (1975).

22. Dugas, D.J., Fuel from Organic Matter, Paper P-500, Rand Corp., Santa :: Monica, Calif. (1973).

23. Larue, J.L., The Heat Value of Various Agricultural Crop Residues and Sewage Sludge Compost, National Student Journal of the American Society of Agricultural kngineers (1975).

24. Oursbourn, C.D., W.A. LePori, R.D. Lacewe11, K.Y. Lam, and O.B. Schacht, Energy Potential of Texas Crops and Agricultural Residues, Texas Agricultural Experiment Station, College Station, Texas (Feb. 1978).

25. Lipinsky, E.S., W.J. Sheppard, J.L. Otis, E.W. Helper, T.A. McClure, and D.A. Scantland, Comprehensive Evaluation of Corm, Vol. 5, System Study of Fuels from Sugarcane, Sweet Sorghum, Sugar Beets, and Corn, Battelle Laboratories, Columbus, Ohio (1977).

26. Goss, J.R., Food Forest Wastes -- Low-Btu Fuel, Agricultural Engineering (Jan. 1978).

27. Brady, N.C.. The Nature and Properties of Soil6, Macmillan, New York (1974)

28. Lyles, L., Possible Effects of Wind Erosion on Soil Productivity, Journal of Soil and Water Conservation 30(6), 279-283 (1975).

29. Tisdale, S.L., and W.L. Nelson, Soil Fertility and Fertilizers, Macmillan, New York (1975). 
30. Adams, E.P., L.A. Derscheid, L.O. Fine, and M.S. Argabright, Do You Realiy Want to Remove Crop Residue? South Dakota Agriculture Experiment Station, Brookings, S.D. (1978).

31. Allison, F.E., Soil Organic Matter and its Role in Crop Production, Elsevier, Amsterdam (1973).

32. Larson, W.E., R.F. Holt, and C.W. Carlson, Residues for Soil Conservation, Crop Residue Management Systems, W.R. Oschwald, Ed., Am. Soc. of Agronomy Spec. Pub: No: 31, pp. 1-15 (1978).

33. Pimental, D., L.E. Hurd, A.C. Bellotti, M.J. Forster, I.N. Oka, O.D. Sholes, and R.J. Whitman, Food Production and the Energy Crisis, Science .182(4111), 443-449(1973).

34. Pimental, D., World Food, Energy, Man and Environment, Energy, Agriculture and Waste Management, Proc. 1975 Cornell Agricultural Waste Management Conf., Ithaca, N.Y., pp.5-16 (1975).

35. Odell, R.T. and W.R. Oschwald, Productivity of Illinois Soils, University of Illinois Cooperative Extension Service Circular 1016, Urbana, Illinois (1970).

36. IlZinoi6 Agronomy Handbook 1975, Cooperative Extension Service Circular 1104, University of Illinois College of Agriculture, Urbana-Champaign, I11. (Dec. 1974).

37. Garman, W.H., D.A. Williams, A.W. Tenny, and E.T. York, Jr., Our Land and its Care, Fertilizer Institute, Washington, D.C. (1952).

38. Morrison, F.B.; Feeds and Feeding, Morrison Pub. Co., Clinton, Ia. (1959).

39. Nelson, D.M., and R.G. Loehr, Conservation of Energy and Mineral Resources in Wastes through Pyrolysis, Agriculture and Waste Management, Ann Arbor Science, Ann Arbor, Mich. (1975). 


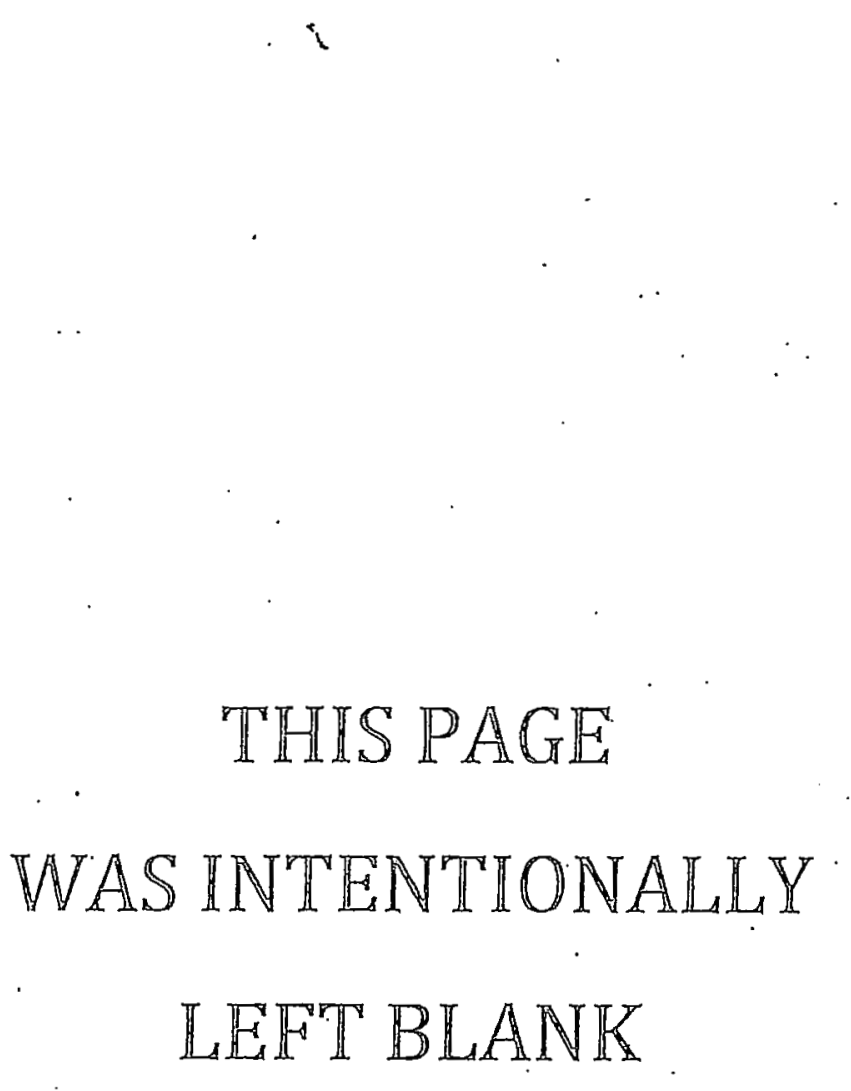




\title{
5 WHEAT RESIDUE PYROLYSIS (GASIFICATION)
}

\author{
ABSTRACT
}

This section analyzes capital and environmental costs of energy recovery through pyrolysis of wheat residue to produce a low-Btu fuel gas. The analysis is based on use of a model gasifier developed for corn residues. Used for gasification of wheat residue, the unit would consume 1.58 tons of residue per hour and would produce $73,846 \mathrm{ft}^{3}$ of gas with a heating value of $130 \mathrm{Btu} / \mathrm{ft}^{3}$. The system is designed to be used on large farms, where it could be used to operate machinery such as irrigation pumps or grain dryers. Use of the system is commercially sound, but complete removal of wheat residues rapidly depletes the soil, and extensive soil management would be necessary to maintain soil productivity. Air pollution is the main environmental problem associated with pyrolysis.

\subsection{INDRODUCTION}

\subsubsection{General System Description}

Pyrolysis is the thermochemical alteration of organic matter in the absence of air. The first material pyrolyzed by man most likely was wood, and the end-use energy produced was charcoal, a cleaner-burning fuel. This simple approach to pyrolysis is still one of the most widely practiced biomass conversion strategies in the world. Brazil has an intensive national program to increase charcoal production, and today $40 \%$ of the energy needs of the Brazilian. steel industry (approximately 2 million tons annually) are supplied by charcoal.1

The principal products of pyrolysis are gas, a highly carbonized solid residue called char, and oil-like liquids with a high tar content. The proportions of char, oil, and gas produced depend on the chemical composition of the feed, its preparation, the reaction temperature and pressure, and the time the material stays in the reactor. 2-5 Heat for pyrolysis may be externally applied to the biomass (true pyrolysis), or it may be produced by combustion of part of the biomass itself.

The modern method of charcoal production from wood is carried out in a steel retort. The wood is externally heated for $20-24$ hr at $500-700^{\circ} \mathrm{F}$ near atmospheric pressure.6,7 The process is often referres to as destructive wood distillation because certain chemical products are produced in addition to charcoal. Disclilatiun of one cord $(4,000 \mathrm{lb})$ of wond yields $7,000-12,300 \mathrm{ft}^{3}$ of condensable gas, 900-1,100 lb of charcoal, 200-300 gal of raw pyroligneous acid, and $2001 \mathrm{~b}$ of acetate of 1 ime. 7

Liquefaction of biomaterials occurs at $400-700^{\circ} \mathrm{F}$ at pressures ranging from 1,000 psig to 4,000 psig.8-10 Table 5.1 gives the percent conversion of some agricultural and forestry residues to oil. A typical catalyst used in this process is sodiun bicarbonate. This process can produce an oil very similar to No. 6 fuel oil. 11 The properties of the two oils are summarized in Tahle 5.2. 
Table 5.1. Conversion of Various Cellulosic Wastes to 0ila

\begin{tabular}{lcccccc}
\hline Raw & $\begin{array}{c}\text { Amount } \\
\text { Material }\end{array}$ & $\begin{array}{l}\text { Time at } \\
\text { Reaction } \\
\text { Temp. }(\mathrm{hr})\end{array}$ & $\begin{array}{l}\text { Maximum } \\
\text { Pressure } \\
(\text { psig) }\end{array}$ & $\begin{array}{c}\text { Conver- } \\
\text { sion } \\
(\%)\end{array}$ & $\begin{array}{c}\text { Oil } \\
\text { Yield } \\
(\%)\end{array}$ & $\begin{array}{c}\text { Co used } \\
(\mathrm{gm} / 100 \text { gm } \\
\text { oil) }\end{array}$ \\
\hline Cornstalks & 50 & 1 & 1,760 & 95 & 42 & 21 \\
Corncobs & 100 & 1 & 2,400 & 95 & 38 & 9.7 \\
Rice Hulls & 50 & 1 & 1,600 & 97 & 40 & 25 \\
Newsprint & 50 & 0.5 & 1,640 & 88 & 40 & 21 \\
Pine Bark & 50 & 1 & 1,600 & 83 & 32 & 45 \\
\hline
\end{tabular}

Source: ref. 11.

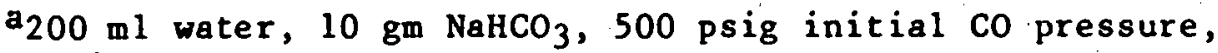
$482^{\circ} \mathrm{F}$ reaction temperature.

Table 5.2. Properties of No. 6 Fuel oil and Pyrolytic 0il

\begin{tabular}{lcc}
\hline Property & $\begin{array}{c}\text { No. 6 } \\
\text { Fuel Oil }\end{array}$ & $\begin{array}{c}\text { Pyrolytic } \\
\text { Oil }\end{array}$ \\
\hline Btu/lb & 18,200 & 10,500 \\
Specific Gravity & 0.98 & 1.30 \\
Pounds per Gallon & 8.18 & 10.85 \\
Flash Point ( $\left.{ }^{\circ} \mathrm{F}\right)$ & 150 & 133 \\
Viscosity (SSU) at $190^{\circ} \mathrm{F}$ & 340 & 3,150 \\
Pumping Temperature ( $\left.{ }^{\circ} \mathrm{F}\right)$ & 115 & 160 \\
Atomization Temperature $\left({ }^{\circ} \mathrm{F}\right)$ & 220 & 240 \\
\hline
\end{tabular}

Source: ret. 11 .

Methane is the main gas component of pyrolysis if the reaction is carried out at high temperature and pressure $\left(2,000^{\circ} \mathrm{F}, 1,000 \mathrm{psig}\right)$. Methane production is boosted by injecting water into the reactor. 12 The water reacts with the hot char to produce carbon monoxide and hydrogen, and methane generation then proceeds by the following routes:

$$
\begin{gathered}
\mathrm{C}+2 \mathrm{H}_{2}+\mathrm{CH}_{4} \\
\mathrm{CO}+3 \mathrm{H}_{2}+\mathrm{CH}_{4}+\mathrm{H}_{2} \mathrm{O}
\end{gathered}
$$

Under even higher pressures (up to 4,000 psig), methanol can be formed from the reaction of carbon dioxide and hydrogen gas.13,14. The use of various chemical catalysts also can affect the volume and composition of gas produced. 15,16

In this section, pyrolysis is examined for the production of a lowBtu fuel gas from wheat residues under conditions of low pressure and relatively high temperature (about $1,600^{\circ} \mathrm{F}$ ). The reaction is a two-stage process in which part of the biomass in the reactor is combusted, with a limited 
air supply, to raise the temperature in the gasifier to about $1,600^{\circ} \mathrm{F}$ to pyrolyze the remaining biomass. Steam is often injected to react with the char to generate hydrogen and carbon monoxide gas.

The composition of the gas produced by such a gasifier unit and that of a true pyrolysis gas is given in Table 5.3. The large amounts of nitrogen present in gasifier gas are from the air burned to increase the temperature in the unit. It should also be noted that gasifiers convert eight to nine times more of the feedstock to gas than occurs with pyrolysis.

Table 5.4 shows the char composition for different biomass feedstocks. The heating values of these pyrolytic chars range from 5,500 to $8,300 \mathrm{Btu} / 1 \mathrm{~b}$, similar to the heating values of many coals. The ash content reported in various chars from gasifiers is much lower--between $1 \%$ and $20 \% .17,18$ Tars are often generated in gasifiers, but the tar content is usually less than $5 \%$.

\subsubsection{Resource Distribution}

There are many significant wheat producing regions throughout the U.S. The distribution of average wheat harvest is presented in Fig. 5.1. Because of regional variations in productivity, the wheat residue resource selected for study has been analyzed on a regional basis to determine the impacts of residue removal on the environment. A six-state area, the wheat belt, which accounts for $54.6 \%$ of the U.S. wheat crop, 20 has been selected for this study. In these six states (Kansas, Montana, North Dakota, Oklahoma, Texas, and Minnesota), an estimated 96.7 million tons of straw residue were produced, with average residue yields from 1.80 to 2.65 tons/acre. These data were estimated from grain yields with a dry-weight grain:residue ratio of $1: 2.73 .21-25$ Table 5.5 summarizes the crop and crop residue production for wheat in this six-state area.

The soil in this wheat growing area is subjected to high winds, and serious erosion occurs if little residue is left in the field. As with other crops and conversion strategies, careful consideration needs to be given to the soil impacts of crop residue removal for energy production.

\subsection{DESCRIPTION OF MODEL SYSTEM}

\subsubsection{System Description and Equipment}

As for corn residues, the model system selected for this study is an updraft gasifier unit that produces low-Btu gas and char and operates at approximately $1,600^{\circ} \mathrm{F}$. A commercial unit is in operation at Diamond/Sunsweet, Inc., Stockton, California. 27 The unit has a capacity of 28.6 tons per day and produces enough energy to sustain a steam production rate of $8,5001 \mathrm{~b} / \mathrm{hr}$ (15 psig) at a fuel rate of one ton of mulled walnut shells per hour. A natural gas pilot flame is used. A laboratory-scale model similar to this unit has been built at the University of California at Davis.18 


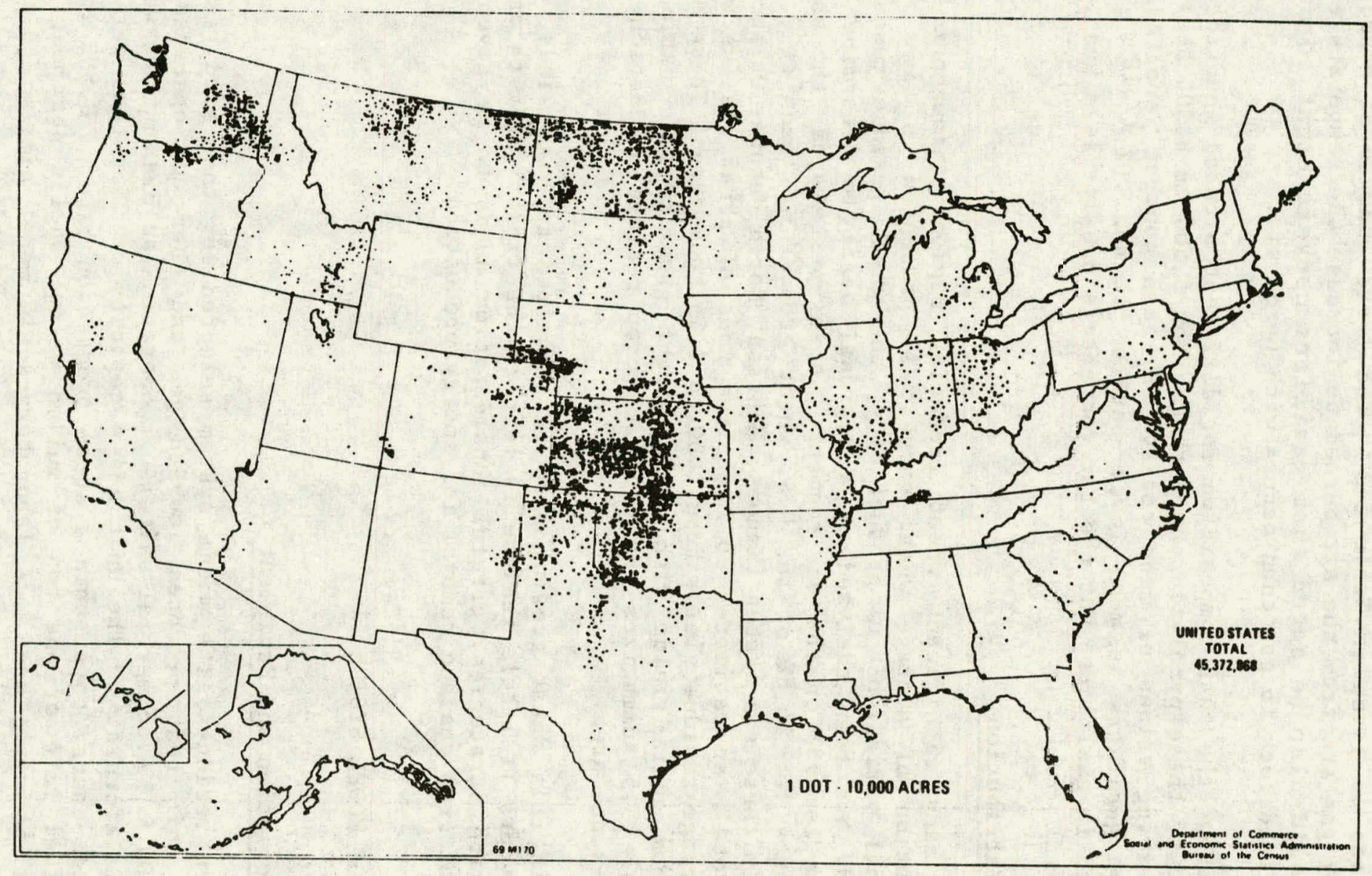

Fig. 5.1. Wheat Harvested, 1969 
Table 5.3. Characteristics of Pyrolytic Gas and Gasifier Gas

\begin{tabular}{|c|c|c|c|c|c|c|c|}
\hline \multirow[b]{2}{*}{ Characteristics } & \multicolumn{4}{|c|}{$\begin{array}{c}\text { Pyrolyt ic Gasa } \\
(\text { wt \%) }\end{array}$} & \multicolumn{3}{|c|}{$\begin{array}{c}\text { Gasifier Gasb } \\
(\text { vol } \%)\end{array}$} \\
\hline & $\begin{array}{l}\text { Annual } \\
\text { Waste }\end{array}$ & $\begin{array}{l}\text { Rice } \\
\text { Hulls }\end{array}$ & $\begin{array}{l}\text { Grass } \\
\text { Straw }\end{array}$ & $\begin{array}{l}\text { Fir } \\
\text { Bark }\end{array}$ & $\begin{array}{l}\text { Cubed Cotton } \\
\text { Gin Trash }\end{array}$ & $\begin{array}{l}\text { Raw Cracked } \\
\text { Walnut Shelis }\end{array}$ & $\begin{array}{l}\text { Broken } \\
\text { Corncobs }\end{array}$ \\
\hline \multicolumn{8}{|l|}{ Components } \\
\hline $\mathrm{H}_{2}$ & 6.1 & 23.3 & 9.6 & 6.3 & 18.3 & 18.4 & 16.1 \\
\hline Co & 21.9 & 28.5 & 53.9 & -14.7 & 16.4 & 20.1 & $18: 7$ \\
\hline $\mathrm{CO}_{2}$ & 55.9 & 40.8 & 26.9 & 64.7 & 11.6 & 8.7 & 9.8 \\
\hline $\mathrm{CH}_{4}^{2}$ & 6.1 & 3.5 & 3.8 & 10.5 & - & - & - \\
\hline $\mathrm{C}_{2} \mathrm{H}_{2}$ & 0.5 & 0.8 & 0.8 & 1.0 & - & - & - \\
\hline $\mathrm{C}_{2}{ }^{+}{ }^{2}$ & 1.8 & 0.8 & 2.8 & 1.2 & - & - & - \\
\hline THC & - & - & - & - & 1.8 & 5.1 & 4.3 \\
\hline $\mathrm{N}_{2}$ & - & - & - & - & 51.4 & 47.3 & 50.9 \\
\hline $\mathrm{O}_{2}$ & - & - & - & - & 0.5 & 0.4 & 0.2 \\
\hline $\mathrm{H}_{2} \mathrm{~S}$ & 7.8 & 2.4 & 2.2 & 1.7 & - & - & - \\
\hline \multicolumn{8}{|l|}{ Other Characteristics } \\
\hline $\mathrm{Btu} / \mathrm{ft}^{3}$ & 226 & 214 & 349 & 222 & 118 & 159 & 141 \\
\hline Gas Yield (\%) & 10.8 & 12.1 & 5.2 & 8.2 & 88 & 91 & 93 \\
\hline Char Yield (\%) & 48.1 & 35.9 & 23.2 & 41.2 & 11 & 9 & 5 \\
\hline
\end{tabular}

apober and Bauer. 11

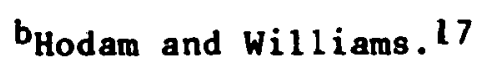


Table 5.4. Analysis of Pyrolytic Chars from Organic Solid Wastes

\begin{tabular}{lcccc}
\hline Characteristics & $\begin{array}{l}\text { Animal } \\
\text { Waste }\end{array}$ & Rice Hulls & Fir Bark & Grass Straw \\
\hline Components (wt\%) & & & & \\
$\quad$ Carbon & 34.5 & 36.0 & 49.9 & 51.0 \\
Hydrogen & 2.2 & 2.6 & 4.0 & 3.7 \\
Nitrogen & 1.9 & 0.4 & 0.1 & 0.5 \\
Sulfur & 0.9 & 0.1 & 0.1 & 0.8 \\
Oxygen & 7.9 & 11.5 & 24.3 & 19.2 \\
Ash & 48.8 & 49.2 & 21.4 & 24.3 \\
Btu/1b & 5,450 & 6,100 & 8,260 & 8,300 \\
Char Yield & 48.1 & 35.9 & 41.6 & 23.2 \\
\hline
\end{tabular}

Source: ref. 11 .

Table 5.5. Wheat -- Grain and Residue Production and Energy Value of Residues: Six States and U.S., 1976

\begin{tabular}{|c|c|c|c|c|c|c|}
\hline Location & $\begin{array}{c}\text { Graina } \\
\text { (bushels/ } \\
\text { acre) }\end{array}$ & $\begin{array}{c}\text { Grain } \\
\text { (tons/acre) }\end{array}$ & $\begin{array}{l}\text { Residueb } \\
\text { (tons/acre) }\end{array}$ & $\begin{array}{c}\text { Total } \\
\text { Acreage } \\
\left(10^{3} \text { acres }\right)\end{array}$ & $\begin{array}{l}\text { Total } \\
\text { Regidues } \\
\left(10^{6} \text { tons }\right)\end{array}$ & $\begin{array}{c}\text { Total } \\
\text { Residue } \\
\text { Energy } \\
\text { Valuec } \\
\left(10^{12} \text { Btu) }\right.\end{array}$ \\
\hline Kang as & 30.3 & 0.90 & 2.50 & 11,300 & 27.8 & 301.9 \\
\hline Mont ana & 30.9 & 0.93 & 2.53 & 5,415 & 13.7 & 148.8 \\
\hline N. Dakota & 24.7 & 0.74 & 2.02 & 11.65 .5 & 23.6 & 256.3 \\
\hline Oklahome & 24.0 & 0.72 & 1.97 & 6,300 & 12.4 & 134.7 \\
\hline Texas & 22.0 & 0.66 & 1.80 & 4,700 & 8.5 & 92.3 \\
\hline Minnesota & 32.2 & 0.97 & 2.65 & 4,056 & 10.7 & 116.2 \\
\hline Six-State Total & - & - & - & 43,426 & 96.7 & $1,050,2$ \\
\hline U.S. Total & 30.3 & 0.91 & 2.50 & 70,824 & 177.1 & $1,923.3$ \\
\hline
\end{tabular}

${ }^{a}$ Data from rof. 20 .

bratio of $1: 2.73$ (grain:residue) was used.24,25

$c_{\text {Based on } 5,430 \mathrm{Btu} / 1 \mathrm{~b}}=\left(10.86 \times 10^{6} \mathrm{Btu} /\right.$ ton $) .26$

The laboratory model system was studied for corn residue gasification. No test run was conducted for wheat straw, so some inferences had to be made concerning the conversion efficiency of this process for straw, although this material can be readily gasified. 5 Table 5.6 presents the chemical analyois of corn residue and straw. The chemical constituents in the two residues are almost identical, although straw has less carbon. The most pertinent distinc$t$ ion between the two materials is that the heating value of corn residues is $12.7 \%$ higher than that of wheat straw.

For development of the mudel system for wheat residue gasification we assume that the energy and material conversion percentages for wheat straw during gasification are identical to those of corn residues. However, a $12.7 \%$ increase in. fuel consumption is required to account for the differences in heating values. Therefore the gas and char produced will have lower heating values. Wheat residue is assumed to have a $15 \%$ moisture content. 
Chopped wheat straw would be the feedstock for the unit. Eightyfour percent of the input fuel is assumed to be gasified, and the principal product is a low-Btu gas $\left(100-200 \mathrm{Btu} / \mathrm{ft}^{3}\right.$ ) with a char residue (30\% of input energy) as a by-product. The remaining heat is not recovered. The mean heating value for dry straw is $6,445 \mathrm{Btu} / 1 \mathrm{~b} .26$ To account for differences of fuel consumption rate because of the moisture in the straw, the following formula is used to approximate the increased wet fuel consumption:

$$
\text { Wet Fuel Consumption }=\frac{\text { Dry Fuel Consumption }}{1.0-\text { Fraction of } \mathrm{H}_{2} \mathrm{O} \text { in Residue }}
$$

This formula simply corrects wet fuel to a dry basis consumption; the wetness of the fuel will also affect the efficiency of the reactor.

\subsubsection{Energy and Material Flows}

The major material and energy flows for our model gasification system are given in Table 5.7. The model system is of a moderate scale so it may be used on the farm near the site of production to reduce the cost of the wheat residue fuel. The Low-Btu gas is primarily designed for use in grain drying, but could be used to operate machinery such as irrigation pumps or grain dryers.

\subsection{ENVIRONMENTAL DATA}

\subsubsection{General Soil Effects}

Total removal of residues from wheat, corn, and cotton fields has the same ultimate effect on the soil although the rate will vary because of differences in crop root system, plant physiology, climatic conditions, and soil properties. Soil destruction begins with the first harvest of residue because the soil is completely exposed to water and wind. Brady28 reports

Table 5.6. Analysis of Curncobo and theat Straw (Dry Basis)a

\begin{tabular}{lcc}
\hline Comporient & Corn Residue & Wheat Straw \\
\hline Carbon (\%) & 44.8 & 42.7 \\
Hydrogen (\%) & 6.1 & 6.0 \\
Oxygen (\%) & 43.6 & 45.1 \\
Nitrogen (\%) & 0.6 & 0.6 \\
Ash (\%) & 4.9 & 5.6 \\
Heat ing Value (Btu/Ib) & 7,268 & 6,445 \\
\hline
\end{tabular}

adapted from wet basis analysis of Johnson and Auth. 26 
Table 5.7. Material and Energy Flows for Gasificationa of Wheat Residues at $20 \%$ Moisture Content

\begin{tabular}{|c|c|c|}
\hline $\begin{array}{l}\text { System } \\
\text { Variable }\end{array}$ & $\begin{array}{l}\text { Material } \\
\text { Flow }\end{array}$ & $\begin{array}{l}\text { Energy } \\
\text { Flow }\end{array}$ \\
\hline $\begin{array}{l}\text { Residue Utilization } \\
\text { Rates }\end{array}$ & $\begin{array}{l}1.58 \text { tons (whest residue) } / \mathrm{hr} \\
(15 \% \text { moisture) }\end{array}$ & $17.4 \times 10^{6} \mathrm{Btu}$ \\
\hline Utilities & & $\begin{array}{l}120 \mathrm{kWh} / \mathrm{day} \\
10 \mathrm{gallons} \\
\text { gasoline/day or } \\
\text { natural gas } \\
\text { equivalent }\end{array}$ \\
\hline Production Efficiency & $\begin{array}{l}73,846 \mathrm{ft}^{3}(\mathrm{gas}) / \mathrm{hr} \\
\left(130 \mathrm{Btu} / \mathrm{ft}^{3}\right) \\
0.2 \mathrm{ton}(\mathrm{char}) / \mathrm{hr} \\
(12,800 \mathrm{Btu} / 1 \mathrm{~b})\end{array}$ & $\begin{array}{l}9.6 \times 10^{6} \mathrm{Btu} / \mathrm{hr} \\
5.2 \times 10^{6} \mathrm{Btu} / \mathrm{hr}\end{array}$ \\
\hline
\end{tabular}

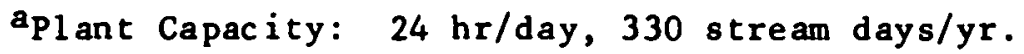

that Wischmeir and Mannering found that removing residues increased runoff from 0.52 inch to 0.98 inch on 678 plot-years of corn. When residues are removed, the raindrop effect destroys surface soil structure, causing puddling, decreased water infiltration, soil compaction, reduced porosity, and a loss of organic matter. In the wheat and cutton growing areas, wind takes over after the soil has dried. Wind sorts the surface material, blowing away the fines and leaving only the semi sterile skeletal matter.27

Organic matter acts as a binding agent to develop and maintain suil structure, which maintains good tilth, increases infiltration, maintains soil porosity, and is a counter force against soil compaction.26,28 organic matter serves as a storehouse for nutrients, increases cation and anion exchange capacity, and chelates micronutrients, protecting plants from potentially toxic concentrations.26,28-30 organic matter in high-organicmatter soils releases approximately 40-80 1b/acre of nitrogen per year for crop uses.29,30 Removal of all residues from fields where corn was grown continuously during a period of 18 years resulted in a decrease in organic matter of $15,0001 \mathrm{~b} / \mathrm{acre} .29$

Not all residues need to be returned to the soil to maintain organic carbon content. Larson and others 33 found that by using conservational tillage (e.g., chisel plow) $1 \%$ to $57 \%$ of the corn area in selected land resource areas of Minnesota and Iowa could have all the residues removed without losing more than 4 tons of soil per acre per year. However, these are only calculated data; the amount of residues that can be safely removed from an area depends on the soil, climatic conditions, and especially management practices such as type of tillage and fertility programs. 33 
The adverse effect of removing wheat residues can be partially overcome by increased fertilizer application. Data presented in this report are only for the first year that crop residues are removed. The second crop year, fertilizer rates must be increased to replace that portion of the nutrients removed by the grain, residue, and erosion. Maintaining usable chemical properties over a period of several crop years could be more costly in terms of energy than the amount of energy in the residue. Unfortunately, the adverse impact on the physical properties of the soil can only be slowed down with higher fertilizer rates. It takes the continual passing of crop residues through the soil and being transformed into organic matter to stop the deterioration of soil physical properties. 3032

\subsubsection{Some Aspects of Wheat Residue Removal}

On 1 y $64 \%$ of the wheat acreage received any fertilization in 1975 although a fertilization program is required for growing wheat on a continuous basis. $24,30,34$ Some of the nutrients in Table 5.8, particularly calcium and magnesium, may not be needed. More fertilizer is needed in the humid eastern region of the Central Plains than in the semiarid western region. 24

Fallowing, as a farming system, is used in the drier areas of the Great Plains. The soil is plowed to control weeds and left in a bare, unprotected state until the next wheat crop is planted. This system conserves plant nutrients, and it allows soil moisture to accumulate for the next crop. The detrimental part of fallowing is the exposure of the soil to the erosive forces of water and wind. Fertilizers are used to ameliorate the depletive results of erosion during the fallow year. $24,36,37$ Unfortunately there is no way to replace the fine material eroded from the soil surface.

Table 5.8. Inputs Needed to Obtain a Wheat Yield of 30 Bushels of Grain and 2.5 Tons of Residue per Acre in a Monoculture Cropping System

\begin{tabular}{lcc}
\hline Input & $\begin{array}{c}\text { Pounds } \\
\text { Per Acre }\end{array}$ & $\begin{array}{c}\text { Pound o Per } \\
\text { Ton of } \\
\text { Residue }\end{array}$ \\
\hline Nutrients & & \\
$\quad$ Nitrogen & 47 & 18.8 \\
Phosphorous & 17 & 6.8 \\
Potassium & 30 & 12.0 \\
Calcium & 145 & 58.0 \\
Magnesium & 76 & 30.4 \\
Seed & 90 & 36.0 \\
Active Ingredients & & 0.2 \\
in Pesticides & 0.5 & \\
\hline
\end{tabular}

Sources: refs. $24,34,35$. 
Removal of all wheat crop residues would not adversely affect the nutrient supply of the soil except for nitrogen (Table 5.9). Nitrogen losses would be 1.1 times the amount applied. Potassium losses would be 1.04 times the amount applied, but supplies of this nutrient in the soils are adequate to handle this loss. Continual removal of the entire crop over time would result in the need to fertilize with sulfur and some micronutrients.

The major effects of total crop removal in the Great Plains are erosion and depletion of organic matter. Estimates have been made that soils in this. area have lost approximately $50 \%$ of their original organic content. 30,31 Lyles 29 reports that stallings found that wind erosion in the Great Plains reduced wheat yields by 4.2 bushels per acre in 30 years. Lyles 29 found that in Geary County, Kansas, wheat yields were reduced 1.3 bushels per acre per inch of topsoil lost by wind erosion. He concluded that even with proper residue management (residues returned to soil), wheat yields were reduced from 0.39 to 1.92 bushels per acre per year, depending on the chemical and physical properties of the surface soil.

Skidmure and siddoway 40 indicate that when all wheat residues are removed from a field with a soil erodibility of 44.6 tons/acre/yr, the potential annual soil loss due to wind erosion $c$ an be as high as 26.8 tons/ acre. Soils that have an erodibility of $89 \mathrm{tons} / \mathrm{acre} / \mathrm{yr}$ can have a potential annual soil loss of approximately 54 tons/acre when all residues are removed. However, when $1,250 \mathrm{lb} / \mathrm{acre}$ flat small grain residue is left on the surface of the soil, potential annual soil loss is only 2.2 and 4.9 tons/ acre, respectively. In terms of nutrient removal, only the losses due to erosion would seriously affect soil fertility. Table 5.10 lists the amounts

Table 5.9. Nutrients and Mineral Matter Removed by Wheat Cropa

\begin{tabular}{|c|c|c|c|c|}
\hline \multirow[b]{2}{*}{ Nutrient } & \multicolumn{2}{|c|}{ Grain } & \multicolumn{2}{|c|}{ Residue } \\
\hline & $\begin{array}{l}\text { Pounds } \\
\text { per Acre }\end{array}$ & $\begin{array}{l}\text { Pounds per } \\
\text { Ton of Grain }\end{array}$ & $\begin{array}{l}\text { Pounds } \\
\text { per, Acre }\end{array}$ & $\begin{array}{c}\text { Pounds per } \\
\text { Ton of Residue }\end{array}$ \\
\hline Nitrogen & 37.5 & 41.7 & 14.7 & 60 \\
\hline Phosphorous & 8.0 & 8.9 & 1.3 & 0.53 \\
\hline Potassium & 9.4 & 10.4 & 22.0 & 8.9 \\
\hline C.a 1 ri im & 0.7 & 0.8 & 4.6 & 1.9 \\
\hline Magnesium & 4.6 & 5.1 & 2.0 & 0.8 \\
\hline Sul fur & 2.0 & 2.2 & 4.0 & 1.6 \\
\hline Copper & 0.02 & 0.02 & 0.007 & 0.003 \\
\hline Mang anese & 0.07 & 0.08 & 0.12 & 0.05 \\
\hline Zinc & 0.01 & 0.01 & 0.04 & 0.02 \\
\hline Boron & 0.07 & 0.08 & 0.15 & 0.06 \\
\hline Iron & 0.14 & 0.16 & 0.37 & 0.15 \\
\hline Mineral Matter & - & - & 407.9 & 166.0 \\
\hline
\end{tabular}

Sources: refs. $30,34,38,39$.

aThe assumption was made that a linear relationship exists between crop yield and nutrient uptake; therefore, data were adjusted for a yield of 30 bushels/acre. 
Table 5.10. Nutrient Replacement Required when Wheat Residue is Removed for Pyrolysis

\begin{tabular}{lcc}
\hline & $\begin{array}{l}\text { Replacement per.Ton } \\
\text { of Residue (15\% mois- } \\
\text { ture) (tons/ton) }\end{array}$ & $\begin{array}{c}\text { Repl acement per } \\
10^{12} \text { Btu } \\
\text { (Tons/1012 Btu) }\end{array}$ \\
\hline Nitrogen & 0.0081 & 1,333 \\
Phosphorus & 0.0029 & 477 \\
Potassium & 0.0052 & 856 \\
Calcium & 0.025 & 4,115 \\
Magnesium & 0.013 & 2,140 \\
\hline
\end{tabular}

of soil nutrients that must be returned to the soil to maintain its productivity per ton of wheat residue removed and per $10^{12}$ Btu generated by gasification of residue.

\subsubsection{Operating Residuals}

The major environmental problem assiciated with pyrolysis is air pollution. The oil and char produced have been marketable in the past? and may be considered by-products instead of pollutants. Although negligible amounts of oil and tar are generated during gasification of wheat residue, a significant quantity of combustible solid waste is generated. It is estimated that 21,094 tons of char (heating value about $29 \times 10^{6} \mathrm{Btu} / \mathrm{ton}$ ) is produced per $10^{12}$ Btu output. This solid waste should have a market value as a solid fuel resource.

There are three major air pollutants: $\mathrm{NO}_{x}$, particulates, and hydrogen sulfide. Experimental data have shown emissions from gasifiers burning wood residues to be $0.703 \mathrm{lb} / \mathrm{hr}$ of particulates and $129 \mathrm{ppm}$ of $\mathrm{NO}_{\mathrm{x}}$. On the basis of these data, we have estimated $\mathrm{NO}_{x}$ emissions for wheat residues to be about $1.01 \mathrm{~b} / \mathrm{hr}$ or 52.1 tons of $\mathrm{NO}_{\mathrm{x}}$ and 36.6 tons of particulates per $10^{12} \mathrm{Btu}$ of energy output: A review of pyrolysis by Nelson and Loehr 41 suggests that $25-30 \%$ of the sulfur goes into hydrogen sulfide. This suggests from our data that from one wet ton of wheat residue $(1.61 \mathrm{~b}$ sulfur/ton) at $25 \%$ conversion of the sulfur to $\mathrm{H}_{2} \mathrm{~S}, 0.34 \mathrm{lb}$ sulfur or $0.36 \mathrm{lb} \mathrm{H}_{2} \mathrm{~S}$ are emitted per ton of residue ( $15 \%$ moisture content). This is equivalent of 29.6 tons $\mathrm{H}_{2} \mathrm{~S}$ per $10^{12} \mathrm{Btu}$ output. However, the $\mathrm{H}_{2} \mathrm{~S}$ from pyrolysis is mostly converted to $\mathrm{SO}_{2}$ upon combustion of the gas.

\subsubsection{Land Requirements}

The land required for the conversion facility is 0.25 acres. The land requirement for residue production is quite large, approximately 0.34 acre/ ton. 


\subsubsection{Water Requirements}

residues.

No water requirements are anticipated for the gasification of wheat

\subsection{ECONOMIC DATA}

\subsubsection{Capital Costs}

The system described for the gasification of what residues is the same as for corn: a gasifier unit, a materials handling unit, and the gasifier with piping and controls. The gasifier has a dry-fuel rating of 28.6 tons/day ( 330 otream days/yr). Tables 5.11 and 5.12 identify and sumarize the capital costs of the system for major equipment purchases and for $10^{12}$ Btu output. The total estimated capital cost for the system is $\$ 112,040$ (1972 dollats).

\subsubsection{Operating and Maintenance Costs}

Labor cost as a percentage of process equipment cost is taken at $9 \%$, and overhead and profit is $10 \%$ of the materials subtotal.

Annual labor ( 1977 dollars) and maintenance costs for this unit have been calculated by Goss 27 as follows:

- Annual Labor $(1,000 \mathrm{hr}$ at $\$ 10 / \mathrm{hr}) \quad \$ 10,000$

- Repairs and Maintenance ( $3 \%$ of new cost) $\$ 4,800$

In addition, the following expenses should be added:

- Supervision (20\% of labor) $\$ 2,000$

- Overhead (60\% of labor plus supervision) $\$ 7,200$

- Residue Cost ( $85 \%$ dry) (12,513 tons/yr at $\begin{array}{ll}\$ 20 / \text { ton } & \$ 250,272\end{array}$

Table 5.11. Construction Costs for Model Gasification Unit

\begin{tabular}{lr} 
Component (Industrial Calugory) & $\begin{array}{c}\text { Cost in } \\
\text { Gasifier, 28.6 Tons/Day (Fabricated Metal Product) }\end{array}$ \\
\hline Piping, Burner, and Controls (Plumbing and Heating Equipment) & 79,794 \\
Storage Bin, 12 Ft x 35 Ft (Fabricated Metal Product) & 37,200 \\
Conveyor Unit (Material Handling Machinery) & 6,138 \\
Labor, 932 Hr at \$13/Hr & 2,083 \\
Transportation. & 12,116 \\
Overhead and Profit & 9,425 \\
Total & 13,464 \\
\end{tabular}


Table 5.12. Capital Costs per $10^{12}$ Btu Output for Model Gasification Unit

\begin{tabular}{|c|c|c|c|}
\hline . & $\begin{array}{c}1977 \\
\text { Dollars }\end{array}$ & Deflator & $\begin{array}{c}1972 \\
\text { Dollar } 8\end{array}$ \\
\hline $\begin{array}{l}\text { Total Capital Cost } \\
\text { Materials } \\
\text { Transportation } \\
\text { Construction Labor } \\
\text { Profit and Overhead }\end{array}$ & $\begin{array}{r}160,220 \\
125,215 \\
9,425 \\
12,116 \\
13,464\end{array}$ & $\begin{array}{l}1.43 \\
1.43 \\
1.43 \\
1.43 \\
1.43\end{array}$ & $\begin{array}{r}112,042 \\
87,563 \\
6,591 \\
8,473 \\
9,415\end{array}$ \\
\hline $\begin{array}{l}\text { Annual System } 10^{12} \text { Btu Output. } \\
\text { Total Capital Cost/1012 Annual Btu } \\
\text { Number of Years to Construct Facility } \\
\text { Expected Life of Facility (years) } \\
\text { Man Years to Construct Facility } \\
\text { Man Years/1012 Btu Annual Output } \\
\text { Estimated Land Use (acres) }\end{array}$ & & $\begin{array}{c}0.0 \\
1,479,102 \\
1 \\
10 \\
0.4 \\
6.1 \\
0.2\end{array}$ & 75 \\
\hline
\end{tabular}

aFor plant site. Additional land also needed to supply residue (approximately 0.34 acre/ton residue).

The residue cost, taken from a study on rice straw utilization by Doble, Miller, and Parson, 42 applies to a 10-mile transportation distance and to either rectangular or rolled bale. The cost estimate is also applicable to chopped straw, which is needed for the gasifier. The cost per ton can range from $\$ 16.52$ to $\$ 29.19$.

Removal of 12,513 tons of residue would require 101 tons of nitrogen, 37 tons of phosphorus, and 65 tons of potasium (residue removal rate is 2.5 tons/acre).

\subsection{SUMMARY OF FINDINGS}

The material, energy, residual, and cost inputs and outputs for this system have been calculated on the basis of $10^{12}$ Btu of energy output by the gasifier. These results are summarized in Table 5.13. It would require 13.2 systems to produce $10^{12}$ Btu to substitute for natural gas or other appropriate fuel. 
Table 5.13. Input/Output Summary for Pyrolysis of Wheat Residues

SIZE :

System is designed to gasify 11,880 tons of residues/yr during 330 stream days of operation. Annual fuel production average is $6.076 \times 10^{6} \mathrm{Btu}$ per ton of residue, or $7.6 \times 10^{10} \mathrm{Btu} / \mathrm{yr}$ a capacity

\section{DE SCR IPT ION:}

Thermochemical conversion of wheat residues occurs in a medium-sized gasification unit; primary energy resource produced is a lowBtu gas for use in drying or machinery operation. An energy by-product is generated in char

\section{COMPONENTS :}

Storage facility, gasifier and controls, and materials handling systems

\section{MAJOR ENVIRONMENTAL}

PROBLEMS :

Air emissions, soil mutrient depletion
INPUT (per $10^{12} \mathrm{Btu}$ ):

Fue l

Residue requirëment:

164,583 tons wheat residue,

$15 \%$ moisture content

(beating value $=10.96 \mathrm{x}$

$10^{6} \mathrm{Btu} /$ ton)

Electricity: $\quad 521,000 \mathrm{kWh}$

Gasoline: 43,421 gallons

(cr natural gas equivalent).

Requires 13.2 gasifier

units operating at capa-

city to produce $10^{12} \mathrm{Btu}$.

Water: None.

Land :

$\overline{0.25}$ acre/plant site, 3.3 acres/ $10^{12}$ Btu, 65,833 acres of corn residue/1012 Btu ( 0.34 acre/ton/ residue).

$\cos T$ ( 1972 dollars):

Capital costs: $\$ 1,479,102$

Operation and maintenance:

$\$ 2,514,160$ (including

residue cost of $\$ 20 /$ ton)
OUTPUT (per $\left.10^{12} \mathrm{Btu}\right)$ :

Air pollutants

Particulates: 36.6 tons

Hydrogen sulfide: 29.6 tons

$\mathrm{NO}_{\mathrm{x}}: 52.1$ tons

Water pollutants

Negligible

Solid waste

Solid by-product has market

value and does not enter

environment as a pollutant

\section{Energy}

Low-Btu gas: $10^{12}$ Btu; can replace natural gas or petroleum fuel

Char by-product:

$0.54 \times 10^{12}$ Btu combustible material $(21 ; 094$ tons)

heating value $=25.6 \times 10^{6}$ Btu/ton 


\section{REFERENCES}

1. Goldemberg, J., Brazil: Energy Options and Current Outzook, Science, 200 (April 14, 1978).

2: Brink, K.L., J.F. Thomas, and G.W. Faltico, The Pyrolysis Gasification-Combustion Proces6: Energy Effectiveness Using Oxygen vs. Air with Wood-Fuel Systems, Fuels and Energy from Renewable Resources, Academic Press, New York (1977).

3. Garrett, D.E., Conversion of Biomass Materials into Gaseous Products, Proc. Second Annual Fuels from the Biomass Symp., Troy, N.Y. (1978).

4. Solar Program A6sessment: Environmental Factors -- Fuels from Biomass, Energy Research and Development Agency, ERDA 77-47/7 (1977).

5. Retrofit '79, Proceedings of a Workshop on Air Gasification, Sponsored by Solar Energy Research Institute, Seattle, Washington (Feb. 2, 1979).

6. Sittig, M., Environmental Sources and Emissions Handbook, Noyes Data Corp., Park Ridge, N.J., pp. 519-521 (1975).

7. Shreve, R.N., Chemical Process Industries, McGraw-Hill, New York (1967).

8. Appell, H.R., The Production of Oil from Wood Waste, Academic Press, New York (1977):

9. Shafizadeh, F., Fuels from Wood Waste, Fuels from Waste, Academic Press, New York (1977).

10. Biomass Liquefaction Program -- Experimental Investigations at Albany, Oregon, Proc. Second Annual Fuels from the Biomass Symp., Troy, N.Y., (1978).

11. Pober, K.W., and H.F. Baver, The Nature of Pyrolytic Oil from Municipal Solid Waste, Fuels from Waste, Academic Press, New York (1977).

12. Huebler, J., F.C. Schora, and B.S. Lee, The Hygas Coal Gasification Prucess, Energy Technology Handbook, D.M. Considine, Ed., McGraw-Hill, New York (1977).

13. Haider, G., Methanol Production from Organic Waste, Academic Press, New York (1977).

14. Wan, E., A Plan for the Introduction of Biomass Based Methanol into the Finergy Economy, Proc. Second Annual Fuels from the Biomass Symp.; Troy, N.Y.(1978).

15. Conversion of Forest Residues to a Methane-Rich Gas, Proc. Second Annual Fuels from the Biomass Symp., Troy, N.Y.(1978). 
16. Walkup, P.C., L.K. Mudge, J.L. Coy, L.J. Sealock, and R.J. Robertus, Investigation of Gasification of Biomass in the Presence of Multiple Catalyst6, Proc. Second Annual Fuels from the Biomass Symp., Troy, N.Y.(1978).

17. Hodam, R.H., and R.O. Williams, Small Scale Gasification of Biomas6 to Produce a Low Btu Gas, Washington, D.C. (1978).

18. Williams, R.O., and B. Horsfield, Agricultural Engineering Dept., University of California, Davis, unpublished information (April 1977).

19. U.S. Department of Commerce, 1969 Census of Agriculture,Vol. 5, Special Reports; Part 15, Graphic Summary, U.S. Government Printing. Office, Washington, D.C. (1973).

20. U.E. Dejàl Lment of Ágriculture, Statistical Reporting Service, Agricultural Statistics 1977, U.S. Government Printing office, Washington, D.C. (1977).

21. Allen, R.R., and J.T. Musick, Wheat and Grain Sorghum Irrigation in a Wide Bed - Furrow System, Trans. ASAE 15(1), 61-63 (1972).

22. Allen, R.R., J.T. Musick, F.O. Wood, and D.A. Dusek, No-Till Seeding of Irrigated Sorghum Double Cropped after Wheat, Trans. ASAE 18(6), 11901213 (1975).

23. Shipley, J. and C. Regier, Winter. Wheat Yields with Limited Irrigation and Three Seeding Rates, North High Plains of Texas, PR-3031, Texas Agricultural Experiment Station, College Station, Texas (1972).

24. U.S. Department of Agriculture, Agricultural Research Service, Wheat in the United States, Agriculture Information Bulletin 386, U.S. Government Printing office, Washington, D.C. (Fob. 1976).

25. Oursbourn, C.D., W.A. LePori, K.D. Lacewell, K.Y. Lam, and O.B. Schacht, Energy Potential of Texas Crops and Agricultural Residues, Texas Agricultural Experiment Station, College Station, Texas (Feb. 1978).

26. Johnson, A.J., and G.H. Auth, Fuels and Combustion Handbook, Mr.Graw-Hill, New Yók (1951).

27. Gose, J.R., Food Foresl Wustes -- Low-Btu Fuel, Agricultural Engineering (Jan. 1978),

28. Brady, N.C., The Nature and Properties of Soils, Macmillan, New York (1974).

29.. Lyles, L., Possible Effects of Wind Erosion on Soil Productivity, Journal of Soil and Water Conservation, 30(6), 279-283 (1975).

30. Tisdale, S.L., and W.L. Nelson, Soil Fertility and Fertilizers, Macmillan, New York (1975). 
31. Adams, E.P., L.A. Derscheid, L.0. Fine, and M.S. Argabright, Do You Really. Want to Remove Crop Residue? South Dakota Agriculture Experiment Station, Brookings, S.D. (1978).

32. Allison, F.E., Soil Organic Matter and its Role in Crop Production, El sevier, Amsterdam (1973).

33. Larson, W.E., R.F. Holt, and C.W. Carlson, Residues for Soil Conser vation, Crop Residue Management Systems, W.R. Oschwald, Ed., Am. Soc. of Agronomy Spec. Pub. No. 31, pp. 1-15 (1978).

34. 1978 Crop Production Guide, Annual Agricultural Short Course and Trade Show, North Dakota Agricultural Association, (Nov. 1977).

35. Midwest Farm Handbook, Iowa State College Press, Ames, Ia. (1957).

36. Hughes, H.D. and E.R. Hanson, Crop Production: Principles and Practices, Macmillan, New York (1957).

37. Martin,.J.H., and W.H. Leonard, Principles of Field Crop Production, Macmillan, New York (1968).

38. Garman, W.H., D.A. Williams, A.W. Tenny, and E.T. York, Jr., Our Land and its Care, Fertilizer Institute, Washington, D.C. (1952).

39. Morrison, F.B., Feeds and Feeding, Morrison Publishing Co., Clinton, Ia. (1959).

40. Skidmore, E.L., and F.H. Siddoway, Crop Residue Requirements to Control Wind Erosion, Crop Residue Management Systems, W.R. Oschwald, Ed., Am. Soc. of Agronomy Spec. Pub. No. 31, pp. 17-33 (1978).

41. Nelson, D.M., and R.G. Loehr, Conservation of Energy and Mineral Resources in Wastes through Pyrolysis, Energy, Agriculture and Waste Management, Ann Arbor Science, Ann Arbor, Mich. (1975).

42. Doble, Miller, and Parson, Management of Rice Straw for Utilization, Transactions of the American Society of Agricultural Engineers, pp. 1022-1028 (1977). 
92

THIS PAGE

WAS INTENTIONALLY

LEFT BLANK 


\title{
6 FERMENTATION OF SUGAR PROCESSING RESIDUES
}

(MOLASSES)

\author{
ABSTRACT
}

This section estimates capital and environmental costs of energy recovery through fermentation of molasses obtained from the processing of sugar from sugarcane and sugar beets. A large-scale model for producing ethanol from molasses was developed from industrial references on molasses fermentation. The model plant would consume nearly 700,000 tons of molasses per year (almost half the U.S. molasses production in 1976) and would produce about 650 tons of anhydrous ethanol per year (annual system energy output $\left.5.475 \times 10^{12} \mathrm{Btu}\right)$. Operation of the plant would interfere with use of molasses as a livestock feed supplement, but some of the demand for molasses could be offset by marketing the yeast and perhaps some stillage produced by the plant for use as animal feed. Air and water pollution would be the main environmental problems associated with ethanol production from molasses.

\subsection{INTRODUCTION}

\subsubsection{General System Description}

The technology for ethanol production coincides with that of the fermentation industry for alcoholic beverages. The processes typically use three types of raw material: sugary materials (mainly molasses), starchy materials (mainly corn and potatoes), and cellulosic materials (mainly waste pulp liquor). 1 Yeasts (usually Saccharomyces cerevisiae) are then used to ferment the simple sugars (mostly monosaccharides and disaccharides) to ethanol.2 The feedstock for fermentation in this study is molasses, a by-product of sugar processing. There are two major sugar crops in the U.S., sugarcane and sugar beets. The system proposed in this report mainly applies to molasses derived from the processing of these two crops. However, because fermentation is such an adaptable process, almost any starch-containing crop (e.g., corn or wheat) could be used.

\subsubsection{Resource Distribution}

It has been estimated that the United States mainland production of molasses for 1976 was $133,676,000$ gallons from sugarcane, 191,700,000 gallons from beets, 50,312,000 gallons of refiners' blackstrap, 10,140,000 gallons from citrus, and $20,500,000$ gallons from hydrol processing, for a tocal of $406,328,000$ gallons. 3 In the same year, the U.S. mainland imported about $411,194,000$ gallons and exported close to $11,215,000$ gallons. Figures 6.1 and 6:2 depict the distribution of sugar beet and sugarcane acreage in the U.S. It is assumed that molasses will be produced at sugar refineries in major producing regions.

Molasses is the final liquor released in the processing of sugar that contains noncrystallizable sucrose. The expressed juice from the feedstock 


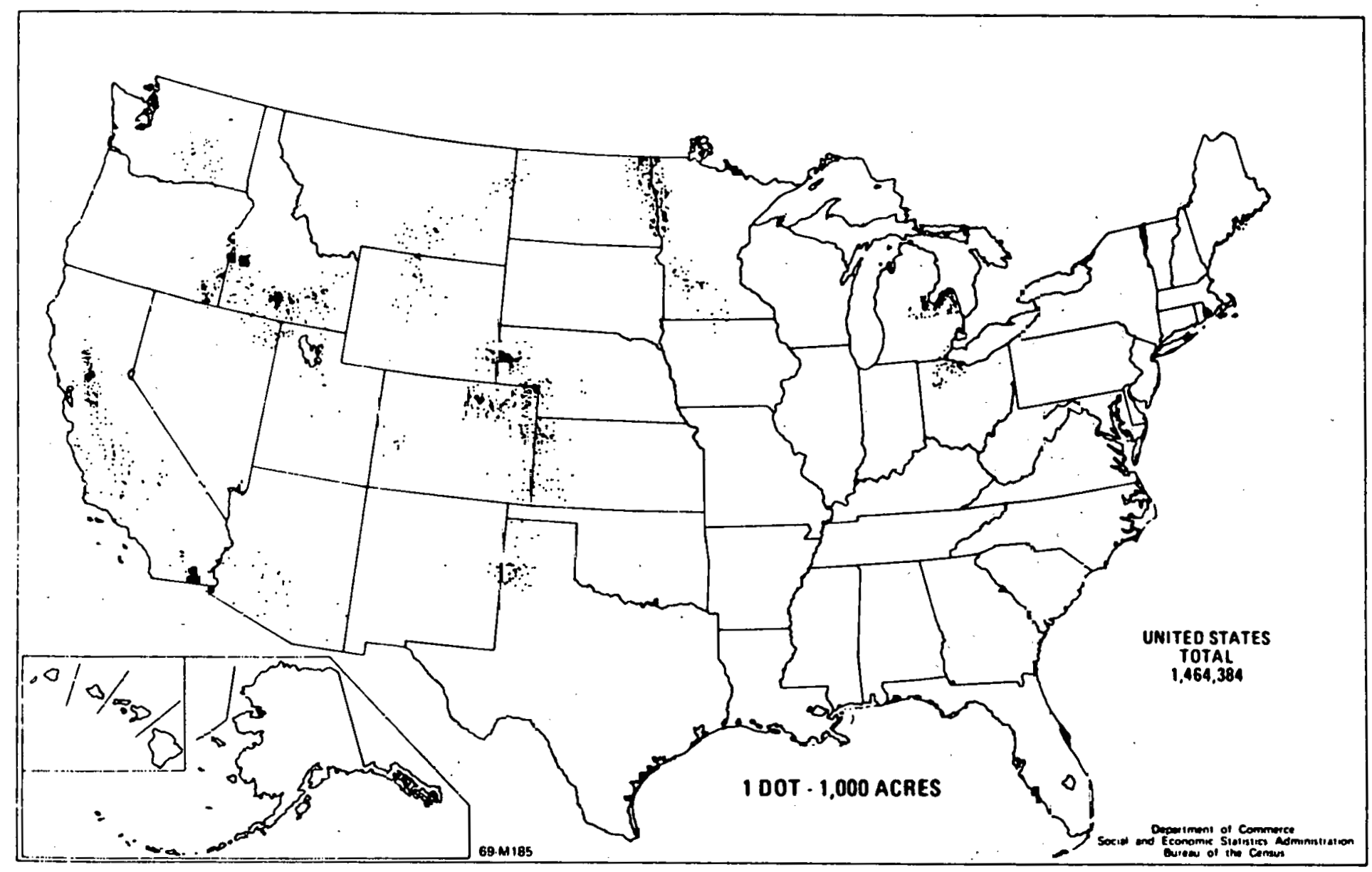

$\stackrel{0}{+}$

Fig. 6.1. Sugar Beets Harvested for Sugar, Class 1-5 Farms, 1969 


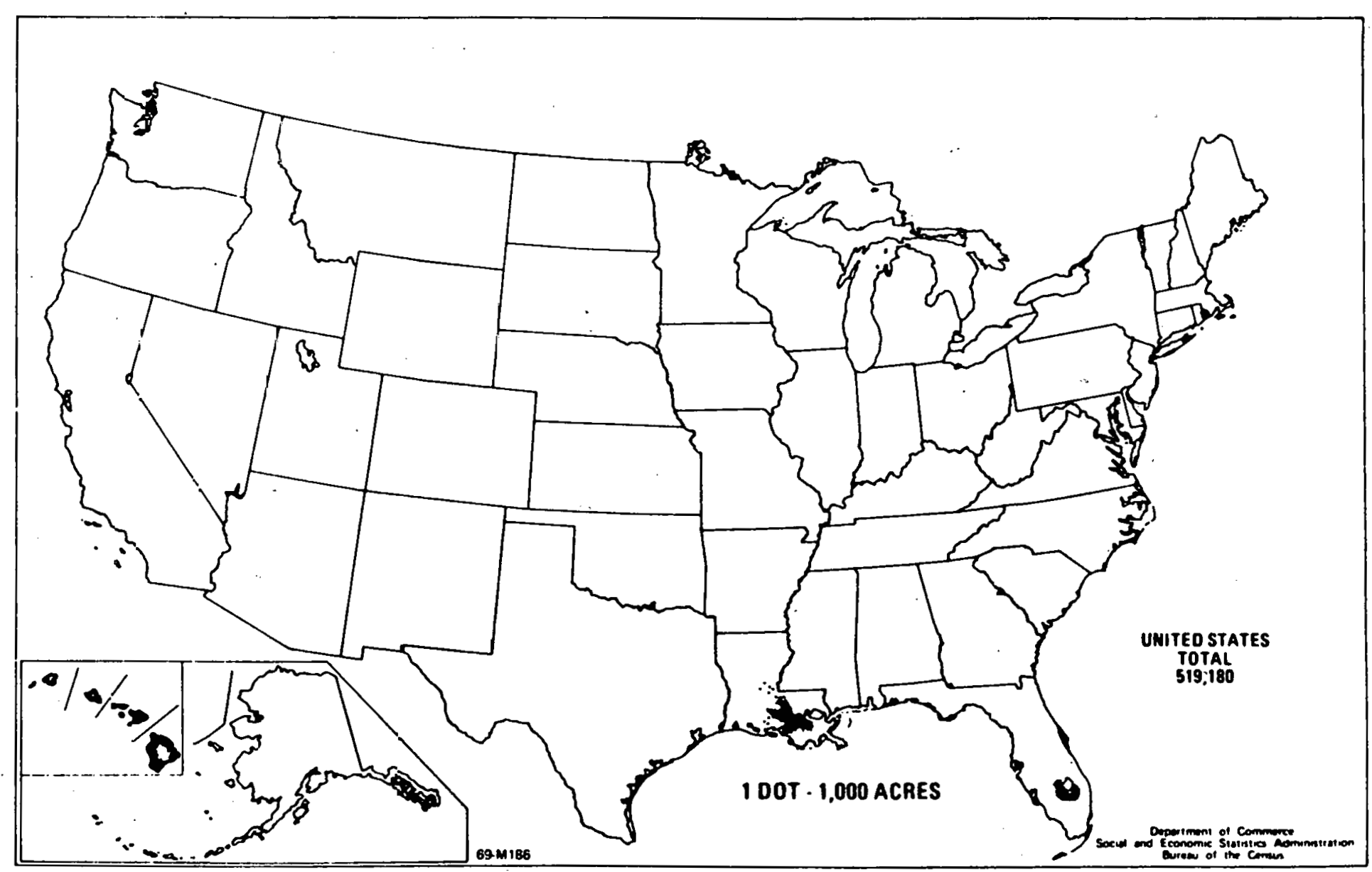

Fig. 6.2. Sugarcane Harvested for Sugar, Class 1-5 Farms, 1969 
(cane, beet) is cleared of impurities, and the raw sugar is concentrated and crystallized by evaporating the juice. The sugar granules are removed by repeated centrifugation, washing, and reconcentration until no more sucrose crystals can be economically formed. The remaining effluent is a dark syrup containing fermentable sugars called molasses.

On the average, molasses contains about $55 \%$ total sugar by weight; sugar from cane molasses is about two-thirds sucrose and one-third invert sugar (glucose and fructose), whereas sugar from beet molasses contains very little invert sugar. 5 Cane molasses is preferred by distillers because of the higher invert sugar concentration, although both types of molasses will support fermentation. According to Paturau's information, 1 the chemical composition of cane molasses is as follows: $17-25 \%$ water, $30-40 \%$ sucrose, 4-9\% glucose, 5-12\% fructooc, 1-5\% other reducing compounds, 2-5\% other carbohydrates, 2-6\% nitrogenous componnds, 2-8\% nonnitrogenuus acids, 7-15\% ash, and some miscellaneous substances. He has also tabulated the constituents of ash: $30-50 \% \mathrm{~K}_{2} \mathrm{O}, 7-15 \% \mathrm{CaO}, 2-14 \% \mathrm{MgO}, 0.3-9 \% \mathrm{Na}_{2} \mathrm{O}, 0.4-2.5 \% \mathrm{Fe}_{2} \mathrm{O}_{3} /$ $\mathrm{Al}_{2} \mathrm{O}_{3}, 7-27 \% \mathrm{SO}_{3}, 12-20 \% \mathrm{Cl}, 1-10 \% \mathrm{P}_{2} \mathrm{O}_{5}$, and $1-7 \% \mathrm{SiO}_{2}$ and insolubles.

\subsection{DESCRIPTION OF MODEL SYSTEM}

\subsubsection{System Description}

A process diagram (Fig. 6.3) has been developed for production of ethanol from molasses using various references on industrial fermentation of molasses.1,5-12 The first phase of the process involves lowering the sugar content from $55 \%$ to $15 \%$ by dilution and adjusting the $\mathrm{pH}$ to between 4 and 5 with sulfuric acid. Other nutrients are not usually required if blackstrap molasses is used, because it contains nonsugar nutrients, although ammonium sulfate and phosphates may be needed. The mash (as the acidified diluced molasses is called) is now transferred to the fermentation vat. Some authurs recommend sterilization, others recommend pasteurization, and still others claim that treatment of the mash is not necessary. For this system we chose a middle-of-the-road approach to help control bacterial contamination of the mash, namely, pasteurization.

A laboratory is required to maintain the purity of the yeast used to inoculate the mash, and special fermenters are necessary to grow the purified strains under aseptic conditions. The yeast is kept in a storage vat until inoculation, and some yeast may be recycled to the vat after fermentation. The volume of the yeast inoculum ahmild rang betwecn 5 and $10 \%$ of the volume of mash.

Fermentation begins upon inoculation and continues for 28 to 72 hours (average 45 hours), producing an alcohol concentration between 6 and 10\%. The temperature may vary between $77^{\circ} \mathrm{F}$ and $95^{\circ} \mathrm{F}$, but it should be usually kept close to $90^{\circ} \mathrm{F}$. During fermentation, carbon dioxide is released at a rate of 5 pounds per gallon of ethanol produced; $0.5 \%$ to $1 \%$ of the ethanol escapes with the gas. 5 The fermentation liquor is now transferred to a centrifuge, and a yeast-rich stream is separated out. Part of the yeast will be returned to the vat for reuse; most will be dried and sold. Approximately $1.51 \mathrm{~b}$ of yeast $(50 \%$ solids) is generated per gallon of ethanol. 8 


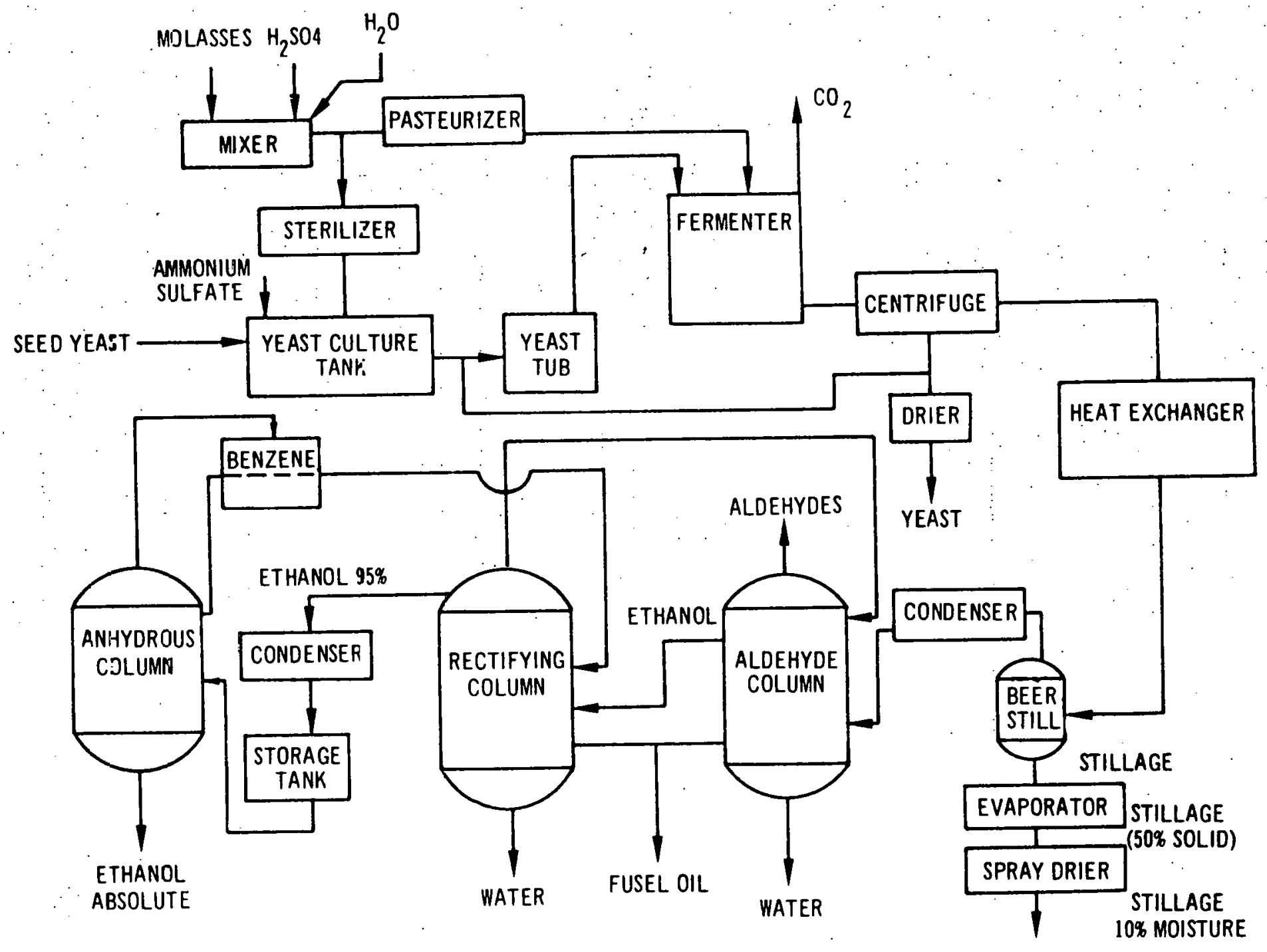

Fig. 6.3. Ethanol Production by Fermentation 
The light stream from the centrifuge is passed through a heat exchanger and into the beer still: The still residue, known as stillage, is then concentrated and dried to $10 \%$ moisture content. It is estimated that $6.41 \mathrm{~b}$ of dry stillage ( $10 \%$ moisture) is produced per gallon of ethano1.8 The overhead from the still is passed through a condenser; the condensate contains $60 \%$ ethanol and $a$ mixture of aldehydes.

The condensate is then charged into the aldehyde column, where these and other highly volatile compounds are boiled off. The ethanol fraction comes off after the aldehyde fraction and then enters the rectifying column. The lower fraction is know as fusel oil, which is a complex mixture of higher alcohols (see Table 6.1). About 0.024 lb of fusel oil per gallon of ethanol is produced. 8 Water known as lutter water leaves the system from the bottom of the column.

The final step in the process is the production of anhydrous ethanol. To achieve this product, benzene is added ( 10 times the quantity of water present) and the system of ethanol and benzene will distill until essentially all the benzene is exhausted. Loss of entraining agent is about 0.036 gallons per 100 gallons of ethanol. Ethanol loss is 0.1 gallon per 100 gallons of ethanol.

\subsubsection{Material, Energy, and Equipment Requirements}

Table 6.2 identifies the main material and energy flows through the system. : These estimates of material and energy flows were taken from references $1,5-12$.

Many pieces of process equipment are needed to equip this facility. (These items are listed in Table 6.5). The major reference for identifying equipment requirements for this system was lipinsky et al.8

\subsection{ENVIRONMENTAL DATA}

\subsubsection{Resource Factors}

Since molasses is a by-product of crop processing, ite uoe has none of the soil effects discussed in previous volumes on corn, wheat, and cotton residues. The major impact of molasses utilization for ethanol production is economic and not related to 1 and resources. Because the proposed fermentation

Table 6.1. Composition of Fusel 0 il

\begin{tabular}{lc}
\hline Component & Weight Percent \\
\hline Ethyl Al cohol & 5 \\
n-Propyl Alcohol & 12.5 \\
Isobutyl Alcohol alcohol & 15 \\
Amyl and Iso-Amyl alcoh & 62.5 \\
Residue Distilling & \\
Higher than $284^{\circ} \mathrm{F}$ & 5 \\
\hline Source: ref. 1. &
\end{tabular}


Table 6.2. Material and Energy Flows For Fermentation of Molasses

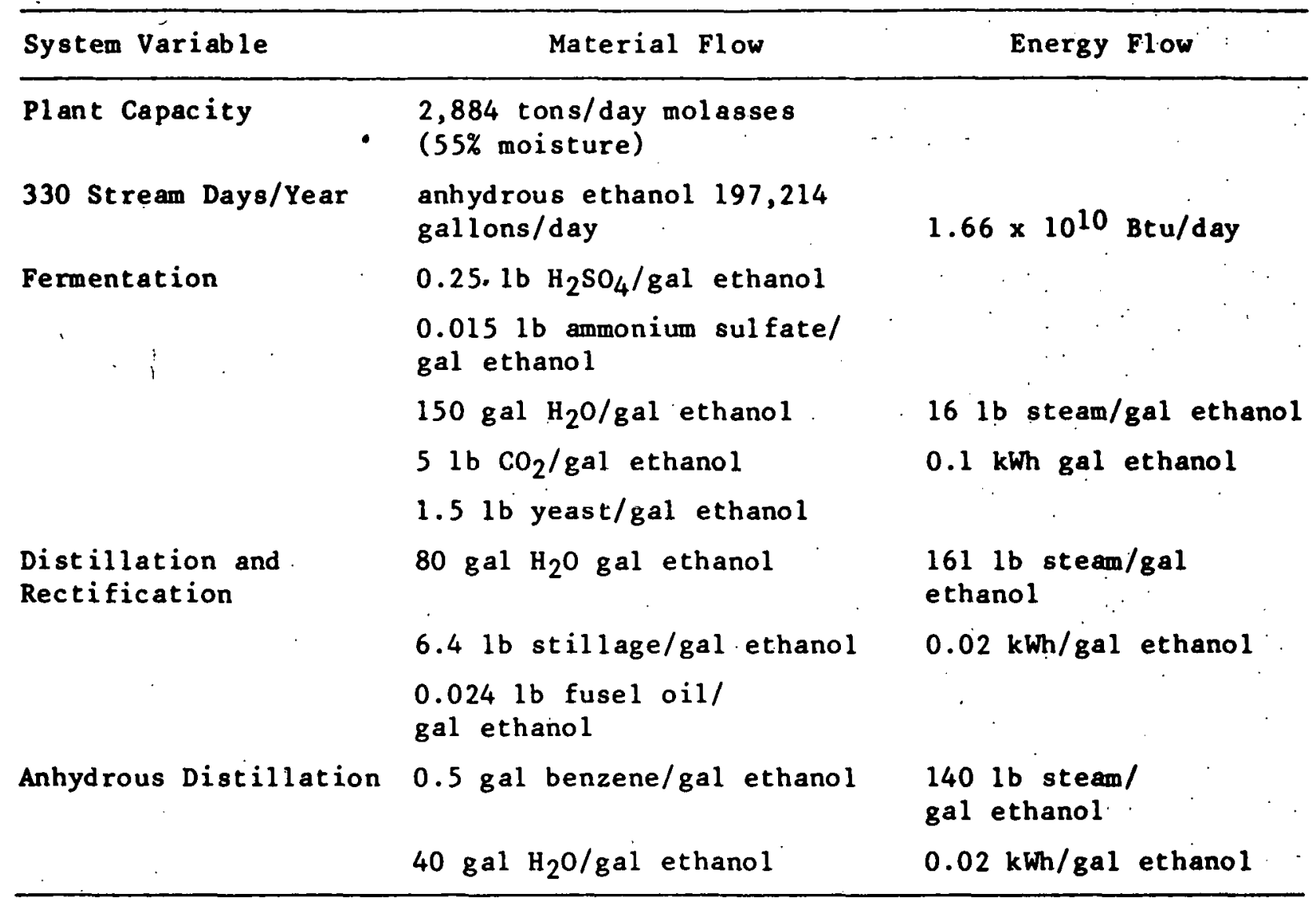

system is so large (it requires about 160 million gallons of molasses per year), it would consume almost half of the 1976 U.S. molasses production. Molasses is a major livestock feed supplement in many areas and there would be serious competition for it, but some of the demand for molasses for feed could be nffset by marketing yeast and some stillage as feedstuffs.

Yeast is an excellent high-protein, feed supplement, and about 50,000 tons per year would be produced in the system. Yeast is a much more nutritious feed than molasses and would have a high market value. About 2,000 tons of stillage would be produced each year. Stillage is also a good feedstuff, and if it were used as such, more than $25 \%$ of the demand for molasses for feed could be offset by substituting it and yeast.

If adequate molasses cannot be obtained for the system, an alternative would be to satisfy some of the demand for molasses with a high-starch grain like corn. The corn would have to be mashed with malted barley or $\alpha$-amylase. (a fungàl enzyme) to convert the starch to a fermentable sugar, but this would require only minor alterations in the process design.

Typically one could expect an anhydrous ethanol yield of about 2.65 gallons from one bushel of corn. If corn were used as feedstock it would perhaps be possible to gasify the residue to provide energy for fermentation. 
This approach would allow the mixing of two biomass conversion methods in one system, corn grain for ethanol and corn residue for process energy.

\subsubsection{Operating Residuals}

Air and water pollution are the two main environmental problems associated with ethanol production. Hydrocarbon air contamination has been estimated to be of the magnitude of 0.01 ton of ethanol and 0.00041 ton of benzene per ton of ethanol produced, that is, a total of 407 tons of hydrocarbons per $10^{12} \mathrm{Btu}$. In addition, carbon dioxide from fermentation enters the atmosphere at a rate of 29,710 tons per $10^{12} \mathrm{Btu}$.

The main water pollutant is from contamination occurring during cooling and distilling and amounts to $2.96 \mathrm{lb} \mathrm{BOD} / \mathrm{ton}$ ethanol produced or 57.9 tons per $10^{12}$ Btu generated. 12

By-products of the process (stillage, fusel oil, and yeast) could be pollutants but usually are considered marketable commodities.

\subsubsection{Land Requirements}

An estimated 300-acre area is needed for the model plant for fermenting sugar-processing residues; 54.8 acres are needed per $10^{12}$ Btu.

\section{3 .4 Water Kequirements}

The water requirements in fermentation arc for cooling $(12,770$ gallons/ton ethanol) and processing ( $3,040 \mathrm{gallons} /$ ton ethanol), equaling $618,060,000$ gallons per $10^{12}$ Btu.

\subsection{ECONOMIC DATA}

\subsubsection{Capital Costs}

A bottom-up approach was used for estimating the capital costs and material inputs of the molasses fermentation system. Plant costs were based on estimated process equipment costs by using previously published cost data for similar equipment 14 and modifying where necessary. Once the process equipment costs were established, other direct and indirect costs were determined from the process equipment estimates. Table 6.3 gives a breakdown of capital costs for a typical multiprocess chemical plant. These estimates are. within the ranges incurred during chemical plant construction. 15 Using Table 6.3 other costs were inferred on the basis of the process equipment cost estimates. These results are found in Tables 6.4 and 6.5 . The total capital cost for the system was estimated at $\$ 52,883,360$ (1972 dollars). 
Table 6.3. Anticipated Distribution of Capital Costs for a Multiprocess Plant

Cost Component

Percent of Total Cost

Site and Preparation

1.5

Buildings and Auxiliaries

10.0

Construction Labor

6.5

Process Material (includes concrete substructures, piping and ductwork, electrical, insulation, process structural, instrumentation, paint) $\quad 13.0$

Process Material Labor

8.0

Process Equipment

32.5

Process Equipment Labor

3.0

Home Office Expense (including overhead)

15.5

Field Office Expense (including overhead)

10.0

\subsubsection{Operating Costs}

Operating costs were taken from estimates of Lipinsky et al.14 for a comparably sized fermentation plant that used sugarcane juice. These costs were assuned suitable to our application, and the breakdown is given in Table 6.6.

In addition to the above operating costs, the amount to be paid for the molasses has to be considered. The estimated value of this commodity is 4.9 cents per pound of fermentable solids (1976 dollars).

Credits may be realized for the following by-products: dried stillage $\$ 60 /$ ton, yeast $\$ 100 /$ ton, and fusel oil $\$ .10 / 1 \mathrm{~b} .14$ No value was assigned to the carbon dioxide. produced.

\subsection{SIMMARY OF FINDINGS}

The material, energy, residual, and cost inputs and outputs for the system were calculated on the basis of $10^{12} \mathrm{Btu}$ of energy output by the system. These results are summarized in Table 6.7. It requires only one fifth of the system's annual production to produce $10^{12} \mathrm{Btu}$.

A major residual effect is the substantial BOD load. It is necessary that all by-products from the system be marketed to reduce such residuals and to increase the energy effectiveness of the system. 
Table 6.4. Capital Costs for Fermentation of Molasses

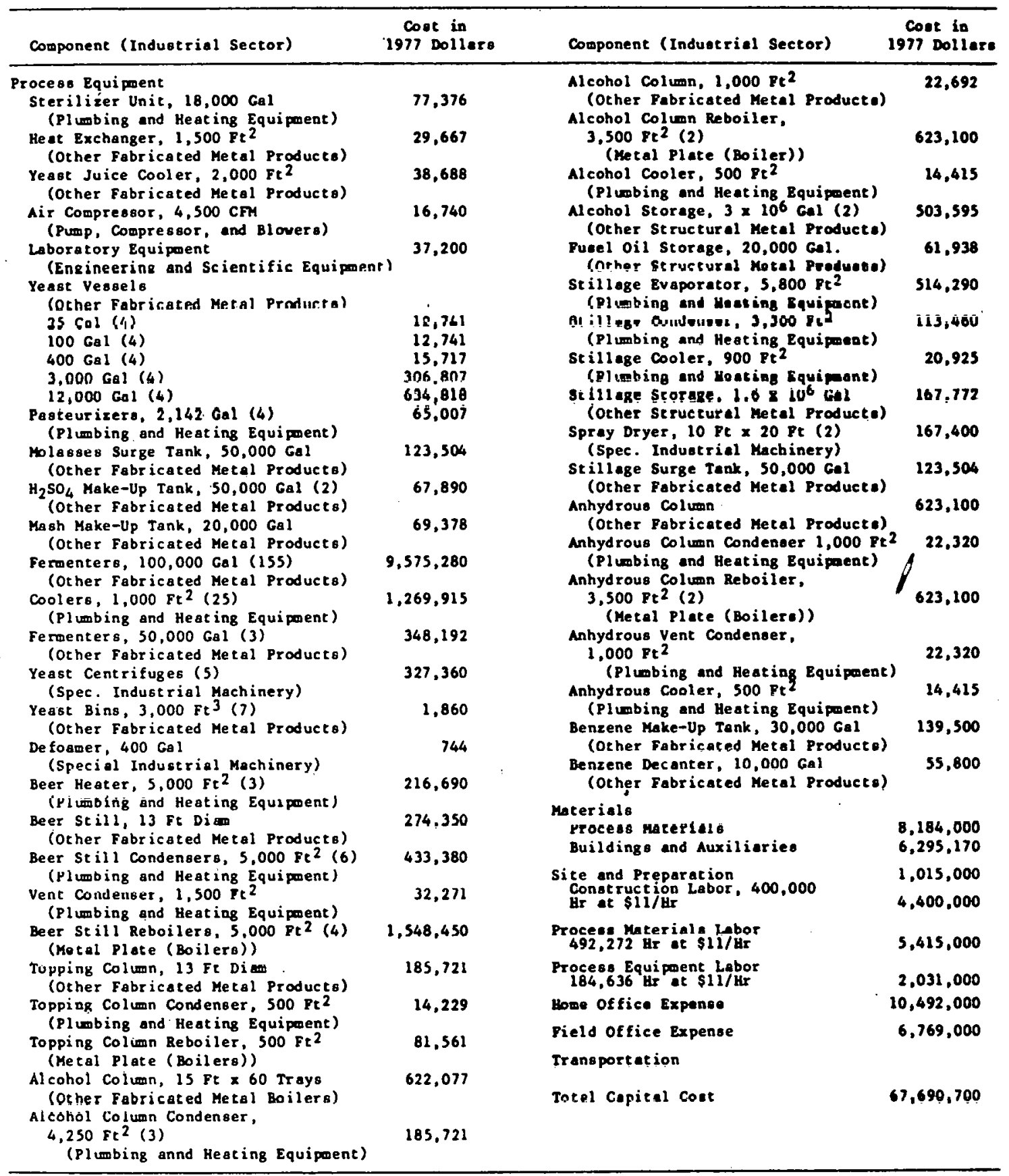


Table 6.5. Capital Costs for Fermentation of Molasses per $10^{12}$ Btu Output

\begin{tabular}{lcrr} 
& $\begin{array}{c}1977 \\
\text { Dollars }\end{array}$ & Deflator & $\begin{array}{r}1972 \\
\text { Dollars }\end{array}$ \\
\hline $\begin{array}{l}\text { Total Capital Cost } \\
\text { Materials }\end{array}$ & $67,690,700$ & 1.28 & $52,883,360$ \\
Transportation & $34,938,891$ & 1.28 & $27,296,000$ \\
Construction Labor & $2,629,809$ & 1.28 & $2,054,537$ \\
Profit \& Overhead & $11,846,000$ & 1.28 & $9,254,688$ \\
Annual System 1012 Btu Output & $18,276,000$ & 1.28 & $14,278,125$. \\
Total Capital Cost/1012 Btu & 5.475 & \\
Number of Years to Construct Facility & $9,659,062$ & \\
Expected Life of Facility (Years) & 3 & \\
Man-Years to Construct Facility & $20+$ & \\
$\quad$ (2,000 Hr/Man Year) & 538.5 & \\
Man-Years/1012 Btu Annual Output & 98.35 & \\
Estimated Land for Facility (acres) & 300 & \\
\hline
\end{tabular}

Table 6.6. Estimated Annual Operating and Maintenance Costs for Ethanol facility

\begin{tabular}{lr}
\hline Cost Element & 1976 Dollars \\
\hline Ammonium Sulfate & 121,000 \\
Phosphoric Acid (feed grade) & 361,000 \\
Sulfuric Acid & 304,000 \\
Turkey Red Oil & 631,000 \\
Utilities & \\
$\quad$ Steam, 5.95 billion Pounds/Year at & \\
$\quad \$ 2$ per Thousand Pounds & $11,900,000$ \\
$\quad$ Power & 156,000 \\
Cooling Water & 450,000 \\
Labor & $1,419,000$ \\
Supervision & 213,000 \\
Maintenance Labor & 614,000 \\
Maintenance Supervision & 123,000 \\
Maintenance Materials & $1,106,000$ \\
Payroli Burden & 711,000 \\
Supplies & 221,000 \\
Indirect Costs & $1,478,000$ \\
Fixed Property Taxes and Insurance & $1,650,000$ \\
Total & $21,458,000$ \\
\hline
\end{tabular}

Source: Lipinsky et al.14 


\begin{tabular}{|c|c|c|}
\hline 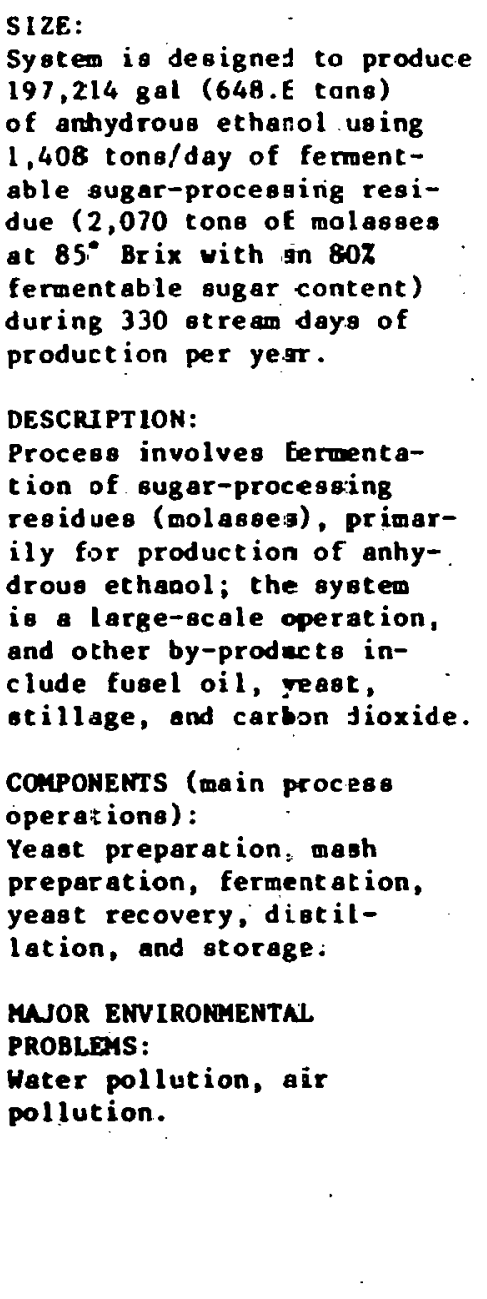 & 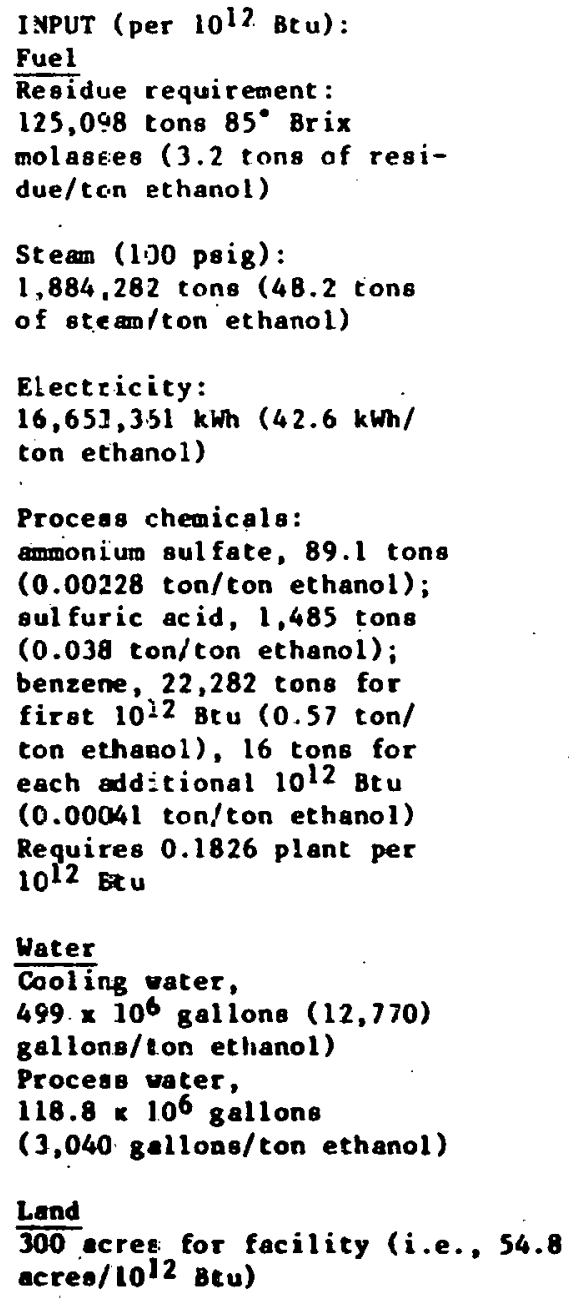 & 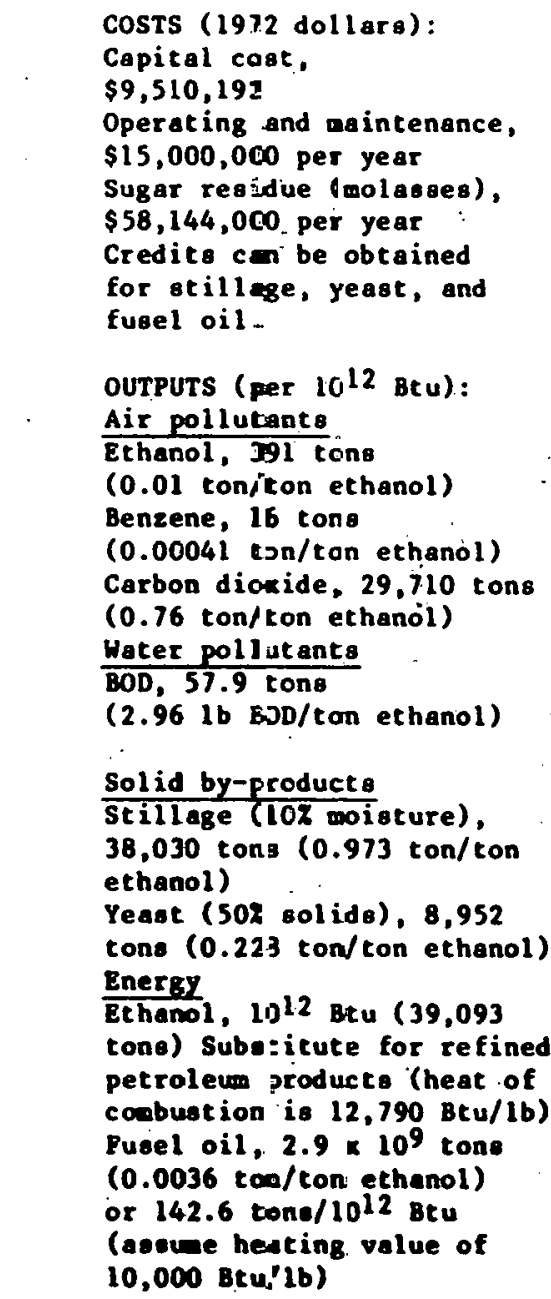 \\
\hline
\end{tabular}




\section{REFERENCES}

1. Paturau, J.M., By-Products of the Cane Sugar Industry El sevier, Amsterdam (1969).

2. Phaff, H.J., M.W. Miuer and E.M. Mrak, The Life of Yeasts, Harvard University Press, Cambridge, Massachusetts (1968).

3. U.S. Department of Agriculture, Statistical Reporting Service, Agricultural Statistics 1977 , Washington, D.C. (1977).

4. U.S. Department of Commerce, 1969 Census of Agriculture, Vol. 5, Special Reports; Part 15, Graphic Summary, United States Printing Office, Washington, D.C. (1975).

5. Lowenheim, F.A. and M.K. Moran, Faith, Keyes, and Clark's Industrial Chemicals, John Wiley and Sons, New York (1975).

6. Proceedings of the International Symposium on Alcohol Fuel Technology, Methanol and Ethanol, U.S. Department of Energy (transl.) November 2123, 1977., Wolf sburg, Federal Republic of Germany, Conf-771175 (July 1978).

7. Yang, V., M.N. Milfront Jr., A. Scigliano, C.0. Massa, S. Sresnewsky, and S.C. Trind ade, Casava Fuel Alcohol in Brazil, Proceedings of the 12 th Intersociety Energy Conversion Engineering Conference, Vol. 1, Washington, D.C. (1977).

8. Lipinsky, E.S., S. Kresuvich, T.A. McClure, E.W. Helper, and W.T. Lawhon, Fuels from Sugar Crops, Battelle Laboratory, Columbus, Ohio (1977).

9: Maule, A.P., Bioengineering Comparison of Batch and Continuous Beer Production, Biotechnology and Bioengineering Symposium, No. 4, John Wiley \& Sons, New York (1973).

10. Mears, L.G., Brazil's Agricultural Energy Program Moving Ahead, U.S. Department of Agriculture Foreign Agricultural Service Report, No. BB-8003 (Jan. 20, 1978).

11: Klostermann, H.J., O.J. Banasik, M.L. Buchanan, F.R. Taylor, and R.L. Harrold, Production and Use of Grain Alcohol as a Motor Fuel -- An Evaluation, North Dakota Farm Research, 35(2) (Nov.-Dec. 1977).

12. Wilke, C.R., R.D. Yang, A.S. Sciamanna, R.P. Freitas, Raw Material Evaluation and.process Development Studies for Conversion of Biomass to Ethanol, Proceedings of the Second Annual Fuels from the Biomass Symposium, Troy, N.Y. (1.978).

13. Sittig, M., Environmental Sources and Emissions Handbook, Noyes Data Corp., Park Ridge, N.J. (1975). 
14. Lipinsky, E.S., W.J. Sheppard, J.L. Otis, E.W. Helper, T.A. McClure, and D.A. Scant land, Corm Agriculture, Vol. 5, System Study of Fuel 8 from Sugarcane, Sweet Sorghum, Sugar Beets, and Corn, Battelle Laboratory, Columbus, Ohio (1977).

15. Perry, R/H. , and C.H. Chilton, Chemical Engineers Handbook, McGraw-Hill, New York'(1973). 